\title{
CAPITALISMO. APUNTES SOCIOLÓGICOS
}

\author{
Carlos Allones Pérez \\ Universidade de Santiago de Compostela
}

http://dx.doi.org/10.5209/rev_NOMA.2012.v34.n2.40741

Resumen.- El texto pretende hacernos conscientes de la tremenda fuerza expansiva del capitalismo, un hecho social que ha transformado por completo a las sociedades occidentales en los últimos 600 años. Utiliza las categorías más sencillas y consolidadas de la teoría del valor-trabajo de Marx, pero su objetivo es mostrar a las relaciones que tienen lugar en el interior de las empresas como relaciones de poder, como relaciones políticas, una nueva servidumbre. Para ello el método de análisis que aplicamos es muy próximo al concepto de 'reacción penal' de Durkheim -incluso en la propuesta que hacemos para su validación empírica.

El estudio se pregunta además por las relaciones históricas y estructurales entre la sociabilidad avanzada de nuestras clases medias y su gobierno por asambleas representativas, que ellas mismas eligen. Para ello recurrimos a la historia del parlamentarismo inglés, desde sus lejanos orígenes sociales, que encontramos en la Invasión Normanda de la isla (1066), hasta su cabal eclosión histórica en la democracia norteamericana (1787). Pero nuestra interpretación es sociológica, busca el sentido de esas transformaciones históricas precoces, y lo halla (implícito) en el contraste entre los tipos-ideales de Comunidad y Asociación establecidos en su día por el sociólogo alemán Ferdinand Tönnies.

A lo largo del texto analizamos también cómo se origina el individualismo en la competición capitalista, y finaliza señalando desde dónde (en el interior de la estructura social) se propaga dicha ideología, como la única considerada de recibo para orientar nuestro comportamiento.

Palabras clave.- plusvalía.- mano invisible.- individuación.- parlamentarismo inglés.- $F$. Tönnies.- medición empírica.- Spencer-Brown.

Abstract.- The text tries to make us aware of the tremendous strength of capitalism as a social fact which has utterly transformed western societies over the last 600 years. It uses the categorical framework of Marx's theory of surplus- value, though only in order to show the capitalist enterprise as a political group, in which a new servitude arises. For that purpose we apply a sociological method of analysis which is very close to Durkheim's concept of 'punitive reaction' -even in the proposal we make for its empirical confirmation.

We also wonder about the historical and structural relationship between our social middle classes and their government by representative assemblies, voted by them. Therefore we focus on the history of the English Parliament, from its remote social origins, which we situate in the Norman Conquest (1066), to its precocious accomplishment in the American Constitution (1787). However, this is a sociological text, not a historical one: so we search for the meaning of that particular and impressive history, and we find an implicit answer in the contrast between the ideal-types of Community and Society, as established by the German sociologist Ferdinand Tönnies.

In our pages we also analyze from where (within the social structure) individualism generates and propagates itself so as to become the only ideology considered capable of adjusting our behaviour to social expectations.

Keywords.- surplus-value.- invisible hand.- individuation.- English parlamentarism.- $F$. Tönnies. - empirical measurement.- Spencer-Brown 


\section{Agradecimientos}

Quisiera expresar mi agradecimiento al profesor Javier Roíz (UCM), en cuyo seminario Foro Interno se gestó primero y se expuso luego por vez primera a discusión pública este trabajo. Al profesor Juan Luis Pintos (USC), y a los componentes del Grupo Compostela de Imaginarios Sociales (GCEIS) que él dirige, porque ahí se sometió por segunda vez a escrutinio académico este texto. A los profesores Julio Cabrera, Iglesias Rábade, Ramón Máiz, Carlos Moya, que lo leyeron y me lo comentaron en privado. Y no menos agradecido estoy a los estudiantes de todos mis cursos de Sociología, aquí en la Universidad de Santiago de Compostela, y cuya presencia en el aula me obliga una y otra vez a exponer y clarificar mi trabajo conceptual.

\section{Presentación}

Todos los libros tienen una historia detrás, y éste también la tiene. Nació al darme cuenta de que, ya desde hace años, la teoría del valor de Marx apenas era citada en las conversaciones y agrupaciones académicas a las que, como sociólogo, asistía. Si se trataba de un seminario de Ciencia Política, por ejemplo, en el que se discutían teorías sobre la Democracia, parecía como si ésta nada tuviese que ver con el mercado, lo cual es sorprendente, porque nuestra vida social está cada día más y más organizada por el mercado y en torno al mercado. Se hablaba de las asambleas representativas, como sistemas virtuosos de gobierno, y de sus defectos prácticos, pero no de que esas asambleas (que nosotros elegimos) lo que hacen, ostensiblemente, es gobernar sociedades cada día más capitalistas. Si se trataba de un seminario de Sociología, atendíamos a distintas interpretaciones y modas académicas (muy activas siempre en esta disciplina), pero ya nadie se acordaba o ponía encima de la mesa la organización asalariada del trabajo, qué tan obviamente condiciona toda nuestra vida contemporánea. Eso de hablar del trabajo asalariado había sido tal vez una moda universitaria allá por mediados de los años 1970', quizás abandonada por algunos en 1981, o en todo caso tras la caída del Muro de Berlín, en 1989.

En uno de esos grupos de discusión rompí mi silencio y una lanza a favor de la teoría del plusvalor de Marx, presentándola como una explicación verosímil del origen del beneficio empresarial, y de la rápida (en términos históricos) emergencia y expansión planetaria del capitalismo, a la que estamos asistiendo. Con prudencia añadí que no creía que fuera la única explicación posible, ni toda la explicación necesaria, pero si una teoría que en todo caso había que tener muy en cuenta y sopesar si se quiere hablar en serio de tales fenómenos sociales. En realidad, de cualquier fenómeno social: también de la expansión planetaria de los gobiernos representativos, de sus ideales y realizaciones; o de aquellos aspectos más novedosos de nuestras sociedades, que tan vivamente llaman la atención de las modernas escuelas sociológicas. Pero como suele ocurrir en estos casos, basta que hablara de capitalismo en relación a la teoría de la democracia, o para comentar determinadas interpretaciones sociológicas, que se me solicitó un escrito donde expusiera 
tales relaciones y opiniones. Y es así como nació este libro, obligándome a dar satisfacción (en lo posible) a un desafío que yo mismo sin querer me había buscado.

Pero en realidad el encargo no era tan difícil de cumplir. En mis cursos de Sociología General y de Estructura Social siempre dedico varias clases a analizar el capitalismo, haciendo uso de la teoría del valor-trabajo. Y digo haciendo uso, porque lo que hago en esos cursos, no es exactamente una mera divulgación de los muy conocidos conceptos marxianos -medios de producción, fuerza de trabajo, capital constante, capital variable, plusvalor, etc. etc.-, sino más bien la utilización de esos conceptos enmarcados dentro de un esquema general, de un método general de análisis, que aplicamos también al estudio de otros hechos sociales, como por ejemplo la familia, el funcionariado, etc. etc.

No daremos en estas páginas una explicación de los procedimientos del método sociológico que, desde hace muchos años, venimos practicando, pues ya anteriormente hemos publicado algunos trabajos proponiéndolo ${ }^{1}$. Aquí tan solo presentaremos los resultados de su aplicación al estudio del capitalismo, y que sea el lector quién juzgue libremente su valía... ¿pero acaso existe una mejor manera de evaluar un método de análisis que por los resultados que con él se obtienen?

Esa misma perspectiva sociológica, también nos había llevado en esos mismos cursos, y también desde hace ya muchos años, a interesarnos por las asambleas representativas por las que nos gobernamos las clases medias del capitalismo avanzado. De ahí nuestro interés por la historia política y cultural de Inglaterra, pues Inglaterra fue pionera entre todas las naciones occidentales, no solo en la revolución industrial, sino que lo fue también, y mucho antes, en ser gobernada por un Rex in Parlamento. Y parece cierto que ayuda mucho a comprender una institución social (cualquier institución social), el estudiarla allí dónde y cuándo por vez primera se origina y echa a andar... ¡Pero naturalmente!, éste no es un libro de Historia, ni es el libro de un historiador: la misma voz sociológica recorre todas sus páginas: nuestro recurso al pasado tan solo sirve aquí, exclusivamente, a los fines de la interpretación sociológica que intentamos.

Por todas estas consideraciones (y sin duda por bastantes otras que me son desconocidas), el caso es que este escrito, que empezó siendo una reflexión sobre la teoría del valor de Marx, y algunos aspectos ideológicos relacionados, se me fue escorando cada vez más hacia temas considerados clásicos de la Economía Política inglesa; y se me fue configurando dividido en cuatro partes (más un pequeño añadido final), que quiero presentar al lector que ahora lo tiene en sus manos:

En la primera, llamada Das Kapital, se hace una utilización de los aspectos más centrales y simples de la teoría de la plusvalía de Marx, pero al final buscamos una posible conciliación de dicha teoría con el concepto de 'mano invisible' de Adam Smith.

\footnotetext{
${ }^{1}$ Cfr. Allones Pérez (1999a, 2004, 2005). Accesos en Google.
} 
En la segunda, llamada Individuación, trabajamos una interpretación de los cambios sociales que juzgamos concomitantes a la expansión del capitalismo, en particular el desarrollo entre nosotros de sociabilidades de clases medias, cuyos hombres y mujeres, para poder sobrevivir, se ven obligados a diseñar para sí mismos largos currículos escolares y profesionales, convirtiéndose (como quién dice) en empresarios de sí mismos, self-made-man o self-madewoman.

En la tercera, llamada English breakthrough, nos preguntamos sí existe o no una relación objetiva entre esas sociabilidades de clases medias y su gobierno por asambleas representativas, que ellas mismas eligen, y para contestarnos, nos decidimos y arriesgamos a esbozar una interpretación sociológica del desarrollo histórico del parlamentarismo en Inglaterra, y sus colonias, desde la invasión Normanda de la Isla (en 1066) hasta la redacción de la constitución de los Estados Unidos (en 1787).

En la cuarta, llamada Individualismo, retomamos el tema de la individuación tratado en la segunda, pero ahora para intentar comprender como esa individuación, que empieza siendo una necesidad social, de supervivencia social, meramente empráctica, se eleva y transforma de repente (como por arte de birlibirloque), en un principio de ordenación moral, se convierte y muta en entusiasta individualismo, y así se nos propaga, difunde, y exige, desde todos los parlamentos occidentales.

Finalmente, encontramos razones para añadir una pequeña reflexión dogmática, o de opinión personal, en la que proponemos superar, dejar atrás el capitalismo, por medio de la creación y mantenimiento de industrias postcapitalistas, que tengan como finalidad proveer a sus clientes de buenos (y duraderos) bienes y servicios, tecnológicamente avanzados, pero no buscar la incesante reinversión de su plusvalía en su ilimitada ampliación.

"Por otra parte, comprendemos que la reacción penal no sea uniforme en todos los casos, dado que las emociones que la determinan no son siempre las mismas. Son, efectivamente, más o menos vivas según la vivacidad del sentimiento herido y también según la gravedad de la ofensa sufrida. Un estado fuerte reacciona más que un estado débil, y dos estados de igual intensidad reaccionan desigualmente según sean más o menos violentamente contradichos. Esas variaciones necesariamente se producen y, por otra parte, son útiles, pues es deseable que el llamado a las fuerzas esté en relación con la importancia del peligro: demasiado débil sería insuficiente: demasiado violento, una pérdida inútil. Dado que la gravedad del acto criminal varía en función de los mismos factores, la proporcionalidad que observamos en todas partes entre el crimen y el castigo se establece, entonces, con una espontaneidad mecánica, sin que sea necesario hacer cómputos sabios para calcularla. Lo que determina la graduación de los crímenes es lo mismo que determina la de las penas; las dos escalas no pueden, por lo tanto, dejar de corresponderse, y esa correspondencia, por ser necesaria, no deja al mismo tiempo de ser útil." La División del trabajo social, Emile Durkheim, 1893 


\section{Das Kapital}

1. Analizamos aquí el capitalismo desde un punto de vista sociológico, considerándolo un juego social, una actividad social distintiva, como cualquier otra, a la manera en que podríamos analizar otros modos de interacción entre individuos, como podrían ser el fútbol, o el tráfico de automóviles, o la instrucción militar.

En todos esos estudios tenemos por costumbre los sociólogos el fijarnos en los comportamientos y conversaciones considerados normativos o convencionales por los miembros del grupo, aquello que estos realizan en sus actividades recíprocamente referidas, y que las dota de finalidad y sentido -como en el fútbol, donde los 11 jugadores de cada equipo coordinan sus movimientos entre sí para meter el máximo número de goles en la meta contraria, e impedir que el equipo contrario los meta en la propia. O como en la instrucción militar, donde lo que se busca es la coordinación total entre los movimientos corporales de cada individuo y los movimientos corporales de todos los demás. O como en el tráfico, donde se pretende la coordinación de las trayectorias de los automóviles, para garantizar en lo posible su fluidez y seguridad.

Pero inevitablemente, toda acción social humana exige también una acción represiva que le es concomitante, un comportamiento represivo por parte de los miembros del grupo, que espontáneamente vigilan, y eventualmente castigan, el comportamiento de cada uno de ellos, cuando (por lo que sea) rompe la expectativa que sobre el mismo tenían los demás. Ese comportamiento represivo, que todos protagonizamos, lo hagamos personalmente, o por delegación o representación política, es, decimos, para los sociólogos, concomitante o fatal a toda acción colectiva, porque si no se diese ésta se volvería inviable, dejaría de ser posible. Si admitiésemos, por ejemplo, que los jugadores de fútbol puedan coger el balón con las manos, el fútbol, tal como lo conocemos, desaparecía, transformándose en algo muy parecido al rugby, del que por cierto, en su día, históricamente, se desgajó. Si no penalizásemos a los conductores que circulan en sentido contrario (en Inglaterra, por la derecha, en España, por la izquierda), el tráfico masivo se haría un caos en nuestras carreteras. Si en los ejercicios de orden cerrado el Sargento no castigase ferozmente cualquier comportamiento insimultáneo de cualquier soldado, la Instrucción Militar no lograría su finalidad disciplinaria, que es precisamente su razón de ser.

Pues así, de esa misma manera sociológica, atendiendo siempre a la vez al comportamiento normativo de los individuos y a su comportamiento punitivo, estudiaremos nosotros aquí el capitalismo, ese sistema social de organización del trabajo que domina ya casi absolutamente las producciones todas en nuestras sociedades occidentales, y que parece en vías de extenderse resueltamente a cualesquiera otras de las sociedades del planeta.

Pero también tendremos que estudiar algo de sus comienzos históricos, que nosotros situamos no sólo, pero sobre todo, bajo el dominio político de los Comunes en Inglaterra. Hacer y expandir ese estudio, el estudio de las 
relaciones objetivas entre capitalismo y gobierno por asambleas representativas, es necesarísimo para nuestro principal objetivo aquí, que no es otro que volvernos conscientes (en lo posible) de nuestra servidumbre capitalista... Ésta parte historiográfica debe intentarse, es imprescindible, aunque no la hagamos demasiado bien, porque no somos historiadores, sino sociólogos... es necesarísima, aunque cometamos errores...

2. Para nosotros lo mismo da decir capitalismo que decir acumulación de capital por medios industriales pues aunque históricamente ha habido (y siempre habrá) acumulación de riqueza por pillaje o conquista, o por comercio de productos exóticos o escasos, como el que practicaban los fenicios en la Antigüedad o los portugueses con Japón en el siglo XVI, por capitalismo nos ceñimos conceptualmente aquí a un solo tipo de comercio en particular, a saber, el comercio con el trabajo ajeno, en cuya maduración se produce la constante invención y aplicación de las máquinas que aumentan su rentabilidad. $Y$ esto de la industria, esto de las máquinas, y de sus exponenciales progresos, es uno de los aspectos más gloriosos (aunque no el único) que trae consigo el capitalismo, y así lo siente la imaginación popular, deslumbrada una y otra vez por la tecnología moderna, precisamente por que guarda buena memoria de los tremendos esfuerzos físicos, comparativamente estériles, que exigía la agricultura antiguamente.

También nos da lo mismo decir capitalismo que decir producción industrial con fines capitalistas

Como es bien sabido, hubo un intento histórico de convertir al Estado en el único capitalista, y a todos sus administrados en funcionarios, siguiendo en esto una desgraciada receta marxista-leninista. Pero como dejó explicado Max Weber, una nómina no es un salario, pues la nómina mide el rango del funcionario, no su productividad, y es tan sólo una millonésima parte del ingreso fiscal del Estado. Tal vez por eso, incapaces de competir con la tremenda espontaneidad y vitalidad de nuestro genuino capitalismo de empresas privadas, los sistemas soviéticos se colapsaron en gran parte por sí mismos, ellos solitos, quedando en pie malamente todavía los ejemplos a no seguir de Cuba y Corea del Norte.

En cambio no existen en Occidente, al menos yo no las veo a mí alrededor, empresas industriales con fines distintos que el capitalista, distintos que esa incesante obtención y reinversión de beneficios, que se obsesiona con su exponencial ampliación. Y por cierto que nada ni nadie nos podría impedir crearlas, o al menos intentarlas, pero para ello tendríamos que librarnos, o ir librándonos, de la superchería del dinero, o ante el poder que da el dinero... ¿Pero para que hablar de algo que no existe?

3. La pregunta fundamental que debemos hacernos es desde luego la misma que la Economía Política inglesa primero, y luego Carlos Marx, y otros, se hicieron a lo largo del siglo XIX: ¿de dónde sale el beneficio empresarial? ¿De dónde sale esa cantidad ingente de dinero que ganan los empresarios? Pues es de la reinversión obsesiva de ese beneficio que surge sin duda la apabullante capacidad de expansión del sistema capitalista, que empezando 
marginalmente en algunas zonas de Europa Occidental allá por el siglo XIV, aplica por vez primera la máquina de vapor al telar en 1787 (de la mano del ingeniero escocés Watt), iniciando entonces sus períodos industriales, para extenderse hoy en día ante nuestros ojos a donde quiera miremos asombrados en el planeta: China, Brasil, Corea del Sur, India, Sudáfrica, México, etc. etc.

Y a nosotros, a pesar de todo lo que se nos dice en contra, en esto de comprender el beneficio empresarial, nos sigue pareciendo válida (nos sigue pareciendo más válida que nunca), la respuesta de Marx, esa teoría del valortrabajo que expuso en su libro Das Kapital, y que parte del supuesto lato (que puede matizarse después todo lo que se quiera) de que el valor objetivo de un objeto consiste en el tiempo de trabajo que, según la costumbre social, se emplea en su producción, y que por eso (genéricamente hablando) nadie cambia un coche por una silla, un piso por un coche, o un avión jumbo por un piso, etc. etc.

Esta verdad de Perogrullo, esta cuenta de la vieja, este concepto de valor, como contenido en el trabajo, en el trabajo socialmente necesario, es el fundamento último y primero de esa denostada teoría de Marx, del que depende absolutamente su sostén y pretensión de realismo. Nosotros pretendemos divulgar aquí dicha teoría, en lo que buenamente sepamos, sin renunciar a limitar su aplicación a lo que convenga a nuestros fines analíticos. Porque aunque esa teoría nos parece una verdad consolidada sobre el capitalismo, no es para los sociólogos, como veremos, la única verdad relevante sobre el mismo.

Repetimos, es una verdad de Pero Grullo, es la cuenta de la vieja, nada hay en El Capital que no sepa cualquier asalariado de cualquier empresa del mundo, nada que no trate de olvidar todos los días cada mañana, cuando se levanta para ir a trabajar a las 7. Pues la buena Sociología, la Sociología cuando es buena, no hace sino decir, poner encima de la mesa, lo que todo el mundo sabe, que es también lo que todo el mundo calla. La Sociología cuando es buena es una aguafiestas, es improcedente, se parece al niño que al ver entrar desnudo al Rey en el salón del trono grita ¡El Rey está desnudo! y todos los cortesanos carraspean, y miran al techo, y hacen como que no lo han oído, porque se trata del Rey, y no les conviene decir ni mú, si quieren seguir en Su presencia. De igual modo, todos los asalariados del mundo saben que están siendo explotados, incluso pueden saber (aproximadamente) en qué cuantía, pero también saben que les conviene seguir siendo explotados.

Por eso no nos interesan, por eso nunca nos han interesado, los recetarios morales y políticos que el propio Marx y sus aláteres de toda época (incluso hoy) han querido, falazmente, deducir de tal teoría. ${ }^{2}$

4. Arrojemos pues la mirada más naïf, más ingenua que podamos, a ese sistema capitalista de producción y, en particular, a la fábrica, que es la parte más pequeña e indivisa que reproduce la naturaleza política del todo. Fábrica a la que los ingleses llaman factory, y si buscamos la palabra "factor" en el

\footnotetext{
${ }^{2}$ Podría ser útil contrastar esta explotación consentida con la servidumbre voluntaria que fue denunciada, en el siglo XVI, por Ėtienne de la Boétie (2008).
} 
diccionario Oxford de etimología de la lengua inglesa, podemos leer entre otros significados: "(mathematics) any of the quantities which multiplied together produce a given quantity XVII", quizás porque aquellos ingleses que contemplaron la primera hora de la organización seriada del trabajo asalariado, y luego la irrupción de la revolución industrial que con ella se originó, quedaban pasmados viendo como las fábricas multiplicaban $(x)$ su capacidad, viendo como de ellas salían mercancías 'como churros'. Porque si Henry Ford en 1909 organiza la primera cadena de montaje de la historia y produce un vehículo modelo T al día, 100 años más tarde la fábrica Citröen de Vigo produce 2300 coches cada día. Y Toyota tiene 300.000 empleados, y Microsoft factura el solito tanto como todo Portugal junto... ¡Así se las gasta el capitalismo! ¡Es de esto de lo que queremos hablar, es de esto de lo que queremos volvernos híper conscientes! Para no olvidar nunca más esto, en ningún análisis social ¡Y menos en los de la Ciencia Política!... ¡Porque es tanto el poder del capitalismo, estamos tan acostumbrados a él, que ya ni siquiera pensamos en ello!

Nos complacemos en describir (con un deje de burla y de superioridad) como machismo los sistemas patriarcales que organizaban la sexualidad y la crianza de nuestros bisabuelos, pero esa palabra era desconocida entre ellos, no se utilizaba, porque el machismo, el comportamiento machista, por ejemplo la virginidad antes del matrimonio de las mujeres, era precisamente el ideal social, lo que se pretendía y lograba en la vida social. De igual manera nadie habla ahora de capitalismo, esa palabra está casi desaparecida, escondida bajo las categorías más asépticas de libre empresa, de mercado, de economía de laissez faire, etc etc Ese sistema que organiza nuestro trabajo va perdiendo su verdadero nombre, a medida que se va convirtiendo en el ideal social que perseguimos, en el comportamiento que buscamos perfeccionar y logramos en efecto realizar: ¿Pues qué otra cosa son las entusiasmadas proclamas que oímos por doquier pidiendo una economía más productiva, diciendo que hay que invertir en $\mathrm{i}+\mathrm{d}+\mathrm{i}$, sobre las bondades de la formación permanente y la flexibilidad curricular, etc. etc.? También nosotros convertimos, como ha hecho toda sociedad humana del pasado (y como hará toda sociedad humana del futuro) las exigencias que impone la supervivencia en nuestra sociedad, en nuestros ideales sociales indiscutidos, en verdades evidentes por sí mismas, en principios aceptados de superioridad moral. Nada nuevo bajo el sol.

5. El empresario no hace más que gastar dinero: debe comprar o alquilar una nave, unos edificios de arquitectura funcional al proceso servicial o productivo que pretende realizar; comprar las máquinas modernas que le permitirán la transformación seriada de las materias primas (que también ha tenido que pagar) en bienes y servicios aptos para satisfacer determinadas necesidades, socialmente sentidas como tales; gastos en energías (generalmente eléctricas) que moverán esa maquinaria infatigablemente hasta su desgaste, obsolescencia o reemplazo; en transportes, que llevarán las mercancías a sus puntos de almacenamiento y venta; en publicidad, que nos harán conocer y desear sus servicios; en impuestos, que legalizarán como suya la propiedad y comercialización de sus productos en un determinado ámbito territorial; etc. etc. Llamemos capital constante $c$ a la suma de todos estos gastos, y de otros que pudieran darse, y que sin duda se darán. 
Pero no sólo tiene que hacer frente a esos pagos, sino a otros de diferente naturaleza, pues ya no se tratará de comprar a precio de mercado bienes y servicios como los que hemos descrito, sino que ahora procederá a contratar individuos capaces de manejar esas máquinas que ha comprado y de realizar esas actividades que pretende. Tendrá que alquilar la actividad de un grupo de individuos, pagándole a cada uno el precio correspondiente por disponer de su habilidad durante un cierto período de su tiempo -digamos 8 horas diarias, 11 meses al año. Llamemos capital variable $v$ al gasto que el empresario tiene en salarios, en alquilar la capacidad de trabajo ajena.

Se establece así contractualmente una relación de dominio (que ejercerá el empresario o capitalista, ya que es el propietario de los medios de producción, que para eso los ha pagado) y de subordinación (por parte de cada uno y todos los asalariados o asalariadas, ya que tan solo aportan al proceso de provisión de servicios o de producción de bienes su capacidad o habilidad para el manejo de dichos medios). Se establece así una relación de mando y obediencia, aunque contractual: pactada entre adultos por medio de un documento legal. Aunque sometida por ello tanto sólo a responsabilidad limitada: a los efectos del proceso servicial o de trabajo explícitamente pactado, del que ambas partes habrán de responder ante una legislación y unos tribunales que le son competentes.

No afecta, a lo que queremos decir aquí, si el empresario es una persona individual, un self-made-man, o una gran corporación que cotiza en bolsa. Lo importante es que se trata de una sola persona jurídica, capaz de emitir una sola voz, de dictar las órdenes que han de obedecer las personas físicas que, organizadas en equipo por dicha voz, realizarán el trabajo.

Aquí el propietario de los medios de producción o capitalista (K), aparece como un capitán de empresa, al mando de un equipo de trabajadores especializados, que, bajo sus ordenes, aplicaran su fuerza de trabajo (f. de t.) al manejo de aquellos medios de producción (que les son ajenos), para realizar conjuntamente, entre todos, una sola operación indivisa $(\Sigma){ }^{3}$

En la época de Marx, a mediados del siglo XIX, se valoraba en las industrias sobre todo la fuerza física, de ahí el nombre de fuerza de trabajo, pero las máquinas y los servicios de ahora, que son elaboraciones cada vez más directas y sofisticadas de las ciencias físicas y legales, precisan de habilidades muy profesionalizadas, y mejor sería decir capacidad de trabajo. Pero honremos nuevamente al gigante sociólogo germano, conservando su expresión.

Indiquemos pues esta relación de poder que estamos describiendo: (K/ $\sum$ f. de t.)

\footnotetext{
${ }^{3}$ Utilizamos el símbolo matemático de sumatorio $\sum$ para señalar que la actividad de cada uno de los asalariados solo tiene sentido precisamente en cuanto que recíprocamente referida a la actividad de todos los demás, como por ejemplo en una cadena de montaje. Todos ellos participan en una sola acción, que es grupal o indivisa.
} 
escribiendo $\mathrm{K}$ con mayúscula y $\mathrm{f}$. de $\mathrm{t}$. con minúscula, para que nunca se nos olvide que se trata de una relación de poder, de una relación política, que vemos entre nosotros los occidentales tan central y tan extendida socialmente, cuanto lo está el trabajo asalariado, es decir, prácticamente a lo largo y ancho de toda nuestra producción servicial y material, y en proceso de constante perfeccionamiento, disciplinamiento, y expansión.

Y esto nos lleva a preguntarnos ¿cabe para la Ciencia Política, para una Ciencia Política que no quiera ser burlada por el poder social que le es contemporáneo, un objeto de estudio más principal, más urgente y cargado de futuro? No quiero decir que sea o que tenga que ser el único objeto de estudio de la Ciencia Política, pero necesariamente, aún estudiando cualquier otro, ante esto de la relación contractual capitalista, hay en todo caso que pronunciarse explícitamente... Porque es co-extensiva con cualquier otra relación social.

Trátese de informáticos, conductores, abogados, economistas, palistas, camareras, publicitas, ingenieros, gerentes, químicas, es igual, al capitalista le es igual, tan solo son mano de obra asalariada, mano de obra subordinada. Y en cualquier caso, según el principio general de equiparación entre valor y trabajo que nos guía, el salario pagará su currículo académico, y (sobre todo) su experiencia laboral. Como si se tratase de una mercancía cualquiera más (y ya veremos que no lo es) el salario tendrá que pagar a precio de mercado el tiempo socialmente necesario para la formación y actual competencia profesional de ese individuo. Pero a cambio, automáticamente, y desde ese momento, esa individua se convertirá en un mero gadget, en un simple subalterno, en un replicante de la persona jurídica cuyo salario ha aceptado. El capitalista tan igual podrá efectivamente emplearla, como caprichosamente decirla: ‘¿Ves esa silla? pues siéntate ahí sin hacer nada hasta nuevo aviso... ¡Ah! ¡Y no fumes!' Y él, o ella, tendrán que obedecerlo.

Ya tenemos pues a nuestro empresario o corporación en posesión legal de todos los medios que precisa para llevar a cabo la producción de bienes o la provisión de servicios que pretende. Ha pagado los medios materiales que la harán posible, ha contratado a los individuos que precisa, dispuestos y capaces para manejar esa tecnología, y ha logrado organizarlos y disciplinarlos para realizar el trabajo que quiere, que no es otro que la transformación seriada o factorial de las materias primas (todavía no aptas para el consumo) en mercancías, esto es: en bienes y servicios que podrán ser eventualmente comprados y consumidos por aquellos que (por lo que sea) los consideren útiles.

No se trata de la bauxita que importamos de un país africano, donde se desarrolla una guerra civil horrible, a cuyos dos bandos por supuesto nosotros armamos y financiamos; no se trata del tocho de aluminio en bruto que sale de la factoría de la costa de Lugo, propiedad de una multinacional norteamericana. No se trata de ese mismo tocho ya perfilado y lacado tal y como sale de las fábricas que tenemos en La Coruña y que surten a gran parte de las carpinterías de aluminio del mercado nacional e internacional; todos esos bienes no son todavía aptos para el consumidor final. Se trata de esa ventana 
de avanzado diseño y versatilidad de usos que cierra la fachada de la habitación en la que estás leyendo este escrito.

No se trata de la multiplicada fabricación seriada de zapatillas Nike en Tailandia, sino de su almacenamiento y transporte y distribución y finalmente venta al por menor en la tienda de La Gran Vía donde yo las he comprado. No se trata del diseño, elaboración, planificación, realización, comercialización, de una serie Disney de TV, y su correspondiente merchandising planetario, sino del acceso a ese episodio que tu hijita está viendo en el salón de tú casa mientras merienda, y que luego comentará entusiasmada con sus amiguitas en el colegio. No se trata de las habitaciones de un hotel céntrico sucias y desordenadas como las ha dejado el cliente anterior, sino de esas mismas habitaciones ya hechas y dispuestas para su uso, que son las que van a contratar y pagar los renovados huéspedes que vendrán esta tarde, etc etc. Sí, por todas partes vemos nosotros contratación de trabajo asalariado (por el empresario) y posterior compra del resultado final de su empleo (por el consumidor), por todas partes vemos capitalismo, ese capitalismo que por ser ubicuo, por estar en todas partes, tiende a pasársenos desapercibido, desactivando al paso, o al menos desenfocando la necesaria atención de las ciencias sociales y políticas.

En la empresa, nuestro esforzado líder corporativo y sus más o menos entusiastas replicantes, han transformado, han mutado las materias primas en mercancías aptas para el consumo, y durante ese proceso de producción de bienes y de provisión de servicios, han añadido tiempo de trabajo, y por ello (según Marx) las han hecho más valiosas, ahora tienen más valor. El empresario es propietario legal de este valor que sólo él (legalmente hablando) ha añadido (pues ha comprado y alquilado con su dinero todo lo necesario para crearlo), y puede entonces con toda libertad fijar el precio que va a pedir por el mismo en el mercado. Claro que no es el único empresario que realiza esa transformación de esas materias primas en esos servicios, y que todo el éxito de su empresa depende de efectivamente llegar a venderlos, sino no podría ganar dinero, y ese es objetivamente todo el norte, toda la razón de ser de sus inversiones. Puede (si quiere) especular con el precio de sus mercancías, desencadenar guerras de precios para hacerse con los mercados de sus competidores, aprovecharse de monopolios zonales o temporales, etc. etc. Y lo hará. Pero por razones que por fuerza más adelante tendremos que discutir, supongamos por ahora aquí -axiomáticamente- que decide fijar un precio que oscila en torno al valor, es decir un precio que corresponde más o menos al tiempo de trabajo socialmente necesario para lograr, con los recursos tecnológicos y organizacionales entre nosotros hoy en día al uso, esa transformación de las materias primas en mercancías que ha realizado. Sea $t$ esa cantidad o precio.

Tenemos ahora ya los tres precios, las tres cantidades a las que se reduce esta cuenta de la vieja que viene a ser la teoría del valor de Marx: el gasto que el empresario ha realizado en medios de producción (c), el gasto que ha realizado en salarios ( $v)$, y el precio $(\mathrm{t})$ que ha decidido cobrar por el trabajo añadido en el proceso productivo que ha fomentado. 
¿Y cómo se relacionan entre sí (según Don Carlos) dichas tres cantidades? Nos explica que hay dos cantidades en juego distintas, que nada tienen que ver entre sí, cada una hija de su padre y de su madre: por un lado, estarían aquellos precios que pretende cobrar por las mercancías que ha producido o servido, y que hemos decidido (axiomáticamente) que son los que representan el valor contenido en ellas, y que sería esta cantidad: $\mathrm{c}+\mathrm{t}$

Y por el otro, aquellos precios que ha tenido que pagar para efectivamente llegar a producir o servir dichas mercancías, y que ha sido esta otra cantidad: c $+\mathrm{v}$

Resta entonces a la primera suma la segunda suma: a la cantidad que cobra por sus mercancías (cuando las vende), lo que ha gastado en producirlas, resultando entonces una cantidad $t$ - v a la que llama plusvalía (pl.), y que sería (según él) el origen último o prius de todo beneficio empresarial: $\mathrm{pl}$. $=\mathrm{t}-\mathrm{v}$

¡Prodigiosa cualidad ésta de la fuerza de trabajo ajena, que a diferencia de un litro de aceite, o de un coche, o de unas vacaciones, cuando se alquila, a medida que se utiliza y emplea, no se consume, no pierde valor, sino que al contrario, engendra nuevo valor, añade más valor, más valor del que ha costado adquirirla! ¡Un valor que puede ser empleado en su compra renovada, en una espiral sin fin, ilimitada! Una mercancía, ésta de la habilidad o capacidad de trabajo de los individuos, que se compra y que se vende en el mercado como cualquier otra -como cualquier otra de las que, por cierto, ella misma (y sólo ella) masivamente difunde-; pero que a diferencia de todas ellas, a diferencia de todas las demás mercancías, que se agotan a medida que se usan, ésta es como un pozo sin fondo, como el fénix que renace día a día de sus cenizas, con exultante fuerza y vigor!

Hemos dicho, la fuerza de trabajo engendra un valor que puede emplearse en su recompra, pero en realidad, como veremos, tenemos que rectificar, y decir que engendra un valor que tiene que emplearse en su recompra, pues hasta en esto también, nuestra insólita, nuestra marxiana mercancía, es también extraña, es también wierd, rara, nunca vista, extravagante... Y cuanto más se consume ¡más obligada está a volver a consumirse! ¡Más tiene que ampliar el ámbito de su dominación!

6. Así pues, todo el truco del capitalismo consiste en que la tecnología permite añadir más valor ( $\mathrm{t}$ ) en el proceso productivo o servicial, que el contenido en la fuerza de trabajo de los adultos que lo realizan (v).Tal simplicidad del capitalismo no debe sorprendernos, pues es verdad de Pero Grullo, y característica común a los sistemas sociales que al extenderse a lo largo y ancho de las sociedades se convierten en verdaderos hechos sociales (en el sentido de Durkheim): sus conceptos fundacionales han de ser, para que eso sea posible, lo bastante simples como para que muy pronto y a la primera, y con harta facilidad todo el mundo los comprenda. Así ocurre también con el fútbol, el tráfico, la instrucción militar, y así ocurría en sus buenos tiempos con el patriarcado... Otra cosa es que dichos conceptos fundacionales, precisamente por su concomitante carácter represivo, han de llegar a hacerse subconscientes en todos nosotros, si queremos sobrevivir por medio de su 
aplicación... ¿y qué otro remedio nos queda? Es ésta una cuestión bien distinta, que más adelante por fuerza abordaremos, quedando desde aquí emplazados a hacerlo.

Todo el truco, decimos, del capitalismo, consiste en que la tecnología permite añadir más valor ( $\mathrm{t}$ ) en el proceso productivo o servicial, que el valor contenido en la fuerza de trabajo de los adultos que lo realizan (v). Porque claro, aunque solo el trabajo es creador de valor, no todos los trabajos crean igual valor, sino que la productividad de los trabajos depende en mucho de las máquinas que se utilizan en ellos ${ }^{4}$. De ahí que los empresarios siempre han estado (hasta cierto punto) dispuestos a financiar las más inmediatamente aplicables disciplinas ingenieriles, aquellas que logran en efecto mejorar las herramientas que aparecen en la mano de los operarios agrupados en las actividades serviciales o productivas que ellos fomentan.

¿Mejorar en qué sentido? En el sentido (desde luego) de que tales herramientas añadan más valor ( $\mathrm{t}$ ), y permitan dañar en lo posible la competencia de los otros empresarios.

Y así, el agrupamiento de tejedores en factories a lo largo del siglo XVIII en Inglaterra, dio lugar a la aplicación de la máquina de vapor (recién inventada) al movimiento de los telares, por el ingeniero escocés Watt, lo que ocurrió en 1787, inaugurándose de este modo la llamada Revolución Industrial, y con ella en verdad una nueva era para toda la humanidad. Pero a continuación, tal artilugio fue aplicado inmediatamente a los ferrocarriles y barcos, consolidando los mercados nacionales e internacionales y condenando por inútiles las tracciones animal y a vela. Los científicos de la Royal Society mientras tanto, y de las universidades europeas, por su lado, avanzaban febrilmente en el descubrimiento de la electricidad, de la fabricación de acero, de las estructuras de hormigón, que permitían levantar las ciudades donde se concentraban los negocios. A lo largo del siglo XIX, el Siglo del Progreso, aparecen sucesivamente, impresionando vivamente la imaginación popular, y cambiando la vida de millones de personas, el telégrafo, el teléfono, la bolsa, la radio, el automóvil, los medios seriados del turismo, los medios industriales de la guerra, etc. etc. Los hermanos Wright, nacidos en Dakota, en los Estados Unidos, y cuyo padre tenía un taller de bicicletas y gustaba llevar a sus hijos a volar cometas los domingos por la tarde, consiguen, siendo aún un par de adolescentes, volar una milla aérea por una combinación simple de ambos artilugios, sentando así las bases de lo que bien pronto había de desarrollarse (en su propio pueblo natal) como fábricas de aviones civiles y de guerra... Después de la Segunda Guerra Mundial nuevo impulso, aprovechando precisamente el esfuerzo tecnológico (sin distinción) de los vencedores y vencidos. Los sistemas de rádar de la guerra submarina, origina la TV. Las bombas A que desarrolló Enrico Fermi en Chicago (y que acabaron con esa guerra) abren paso a la energía nuclear de uso civil. Las bombas teledirigidas alemanas V-1 y V-2, y aún los mismísimos técnicos alemanes que las enviaban sobre Londres, dirigen las carreras espaciales americana y soviética. Los sistemas de desciframiento de códigos de los servicios secretos alemán e

\footnotetext{
${ }^{4}$ Lo que por cierto nos parece a nosotros el error de partida de Böhm-Bawerk (2000) en su intento de crítica frontal al sistema de Marx.
} 
inglés, desarrollan las bases de la informática. Las guerras químicas y bacteriológicas, la bioquímica y biogenética actuales, etc. etc.

¿Cómo no sentirse impresionados ante semejante despliegue de ingenio y poder? ¿Qué viene ahora? ¿Qué viene después? ¿Ordenadores moleculares? ¿Enzimas y neuronas? ¿Cual va a ser la tecnología de uso común entre los adolescentes de dentro de 6 ó 7 generaciones, por no irnos demasiado lejos? Nadie lo sabe, nadie lo puede saber... ¡Esto no ha hecho más que empezar...!

Se nos dirá, con eso sin duda se potencia la capacidad productiva, la capacidad exponencial de añadir valor (t), de acuerdo, ¿pero acaso los salarios (v) no tienen que pagar la cada vez más larga (en el tiempo) y costosa (en medios) formación académica y laboral que exige el manejo de tan sofisticadísima tecnología? Y así es, y así ha de ser, en el sentido más rigurosamente marxiano de la ley del valor que profesamos, y los salarios efectivamente suben, creando el capitalismo de hecho amplísimas capas de clases medias altamente profesionalizadas, que en su momento aquí mismo habremos de caracterizar (en lo que atañe al tema estrictamente económico que nos ocupa). Pero más, mucho más, muchísimo más sube la productividad que los salarios, pues si aquella lo hace exponencialmente, por así decirlo, estos en cambio se ven afectados una y otra vez en su subida por la necesaria incorporación histórica, al capitalismo, primero de todos los campesinos que hagan falta, después de todas las mujeres que hagan falta, y finalmente de todos los inmigrantes que hagan falta... Logrando siempre de este modo (como quién dice) un país de mileuristas, buscando siempre los empresarios y sus corporaciones ampliar el margen $t-v$ que alimenta el plusvalor obtenido ( $\mathrm{pl})$, para luego reinvertirlo siempre en la incesante ampliación de su patética dominación política.

Pero ya digo, a todo esto tendremos que volver más adelante, sobre todo para tratar en algo el aspecto del consumo, inmanente al sistema.

7. Pero Marx desarrolla toda la teoría del valor de manera axiomática, partiendo del principio de que solo el trabajo crea valor y de que por tanto el precio (una mera relación numérica entre cantidades de valor) oscila en torno al valor. ¿Pero como conciliar esto con la evidencia diaria de que son los agentes económicos quienes acuerdan espontáneamente los precios, atendiendo tan solo a lo que en cada momento y circunstancia consideran sus intereses escuetos, subjetivamente calculados?

$Y$ desde luego, ese comportamiento crudamente especulativo -en el que no parece jugar papel alguno el cálculo (que sería por fuerza abstracto) del tiempo de trabajo socialmente necesario que Marx postula- fue con toda razón señalado una y otra vez por los padres fundadores de la Economía Política inglesa.

Nosotros hemos buscado una respuesta a tan chocante contradicción -que sin duda derrumbaría de mantenerse toda la interpretación del capitalismo que estamos intentando-, y hemos dado con el siguiente razonamiento, que como 
todos los nuestros, es de índole sociológica, y que está en buena medida inspirado en algunos fragmentos de Weber ${ }^{5}$.

Recordemos que de todos los comercios, solo la compra y el consumo de fuerza de trabajo ajena engendra valor, crea nuevo valor, produciéndose en los otros intercambios, de cualesquiera otras mercancías, un mero trasvase de valor, donde una de las partes pierde lo que gana la otra, ya que estas otras mercancías (a diferencia de la fuerza de trabajo) se gastan al tiempo que se usan.

Quién mejor sabe esto desde luego es el empresario, que ha llegado a serlo precisamente contratando trabajo ajeno -pues su comercio, comparado con los demás comercios, es mucho más productivo, como lo es una máquina comparada con los sistemas manuales de producción. Su instinto político, de agresión y dominio de las otras corporaciones, al que debe (nunca se olvide) su más celebrada identidad social, le lleva certeramente a buscar modos de reinvertir toda la plusvalía obtenida en la compra de más y más fuerza de trabajo, en la contratación de más y más empleados, invirtiendo una y otra vez en la serialización del trabajo asalariado, que es para nosotros lo específica, distintivamente capitalista.

Pero ocurre que para contratar más trabajo asalariado hace falta producir o servir más, y que para producir y servir más hace falta vender más, y para vender más hay que ajustar los precios, afinar cada vez más los precios, vendiendo cada vez más barato, calculando cada vez con mayor rigor los precios de los objetos o servicios, para que se aproximen todo lo posible al trabajo asalariado efectivamente contenido en ellos, esto es: a su valor, en el sentido marxiano.

De este modo, el self-made-man de otrora, el empresario de raza, o -todavía más- el llamado ejecutivo agresivo o abstracto de la actual corporación, se ve obligado una y otra vez a invadir los mercados de los demás empresarios, consolidando nuevas producciones, servicios y redes comerciales, que le llevan finalmente a alcanzar una posición y tamaño estratégicos. Se produce entonces una sobre ponderación de sus precios en el conjunto de los precios de los mercados en los que actúa, ya que los suyos, hasta cierto punto, y tendencialmente, fuerzan el ajuste también de los precios de los demás, que se van volviendo cada vez más uniformizados, cada vez más regularizados, cada vez más homogenizados... ¡Cada vez más marxianos!:

"El secreto de mi éxito está en pagar como si fuera pródigo y en vender como si estuviera en quiebra."

Henry Ford (1863-1947)

De este modo nos explicamos nosotros rudimentariamente (no somos economistas, sino sociólogos) de que modo las más espontáneas, subjetivas, y reiteradas especulaciones de precios se producen en el libre mercado, pero que al tiempo, ese mismo mercado tiende a descartar (estadísticamente) tales

\footnotetext{
${ }^{5}$ En particular los fragmentos que se refieren a "regularidades de la acción económica" Weber (1964:24); y a "selección de relaciones sociales" Weber (1964:32).
} 
especulaciones, y a seleccionar en cambio los productos y servicios más ajustados a su precio y valor. Que el mercado admite todos los comercios, pero que también hace pesar y perdurar sistemáticamente, más que ningún otro, el comercio con la fuerza de trabajo ajena, y que es por eso mismo precisamente por lo que en efecto se gana a pulso día a día el apodo de sistema capitalista ${ }^{6}$.

8. Para cerrar esta primera parte, terminemos diciendo que somos muchos los que pensamos que urge trabajar en una matematización de la teoría marxiana del valor, que sirva en la Economía para fundar una verdadera ciencia (a la manera en que Newton fundó la Física al matematizar las leyes astronómicas de Kepler). Una verdadera ciencia económica, que tendría por fuerza que ser una principalísima rama de la Sociología, y no esa mal llamada economía que se enseña en las escuelas de negocios de todo el mundo, y que es poco más que un recetario empráctico (y lógicamente fallido).

Tal vez el modelo de Sraffa (1960) pudiera sentar las bases de una tal matematización, capaz de comprobar o desmentir la axiomática marxiana (en los datos de los hechos de la realidad que ella misma señala). Sentar las bases, digo, de los elementos contables de dicha matematización, aunque bien entendido que esos elementos habrían de estar por fuerza subordinados a la construcción de conceptos genuinamente sociológicos, los únicos que en cualquier caso son competentes para medir el capitalismo en su perduración histórica (ya que este es un hecho social como cualquier otro). ${ }^{7}$

Más arriba, muy al final, volveremos puntualmente sobre esto, siquiera sea para dejar indicada la manera en que esa Sociología matemática del capitalismo podría tal vez intentarse.

¡Pero que nadie se engañe o se ilusione! la conciencia colectiva es la única soberana (Durkheim), y esa eventual comprobación empírica no significaría en modo alguno un posicionamiento político en contra de la explotación capitalista. De igual manera que los norteamericanos que gustan del darwinismo televisado de los documentales de National Geographic, son los mismos que luego en la Asociación de Padres de Alumnos exigen que junto a las teorías de Darwin se enseñe a sus hijos el Génesis Bíblico.

\footnotetext{
${ }^{6}$ Es así como Karl Marx y Adam Smith se dan la mano, y cada uno guarda su parte de razón, invalidando y haciendo contraproducentes cualesquiera explicaciones del capitalismo y del libre mercado que busquen prescindir de uno de los dos.
}

Leémos en ADAM SMITH (1776): Wealth of Nations. Cannan Edition, I, 421 -tal y como aparece citado en Hayek (1948:7): "By directing that industry in such a manner as its produce may be of the greatest value, he intends only his own gain, and he is in this, as in many other cases, led by an invisible hand to promote an end which was no part of his intention. Nor is it always the worse for the society that it was no part of it. By pursuing his own interest he frequently promotes that of the society more effectually than when he really intends to promote it."

Porque en realidad lo que separa a los dos autores en la descripción del sistema capitalista es mucho más un posicionamiento moral que un posicionamiento conceptual.

${ }^{7}$ Cfr. Durkheim (1978). 
"Por definición, el todo es antes que las partes, explica las partes; y las partes no tienen sentido si no es con relación al todo. Pues bien, ¿y si no fuera necesariamente así, al menos en algún sentido, de alguna manera? ¿Y si el todo -el sagrado whole explicador- fuese a su vez precisamente explicable desde, y en función de, sus partes? Es decir, de una de sus partes: de la parte dominante, privilegiada, en un todo internamente desequilibrado y asimétrico." Joan F. Mira, prólogo al libro Antropo-lógicas, de George Balandier, 1975

\section{Individuación}

1. Tenemos ahora que describir las ideas e interpretaciones que se generalizan entre quienes protagonizamos estas organizaciones capitalistas del trabajo, ideas que están presentes y han acompañado de manera inmanente todas sus particulares realizaciones, desde sus mismos comienzos históricos, pero que luego, con el tiempo, y ya en nuestros días, esas ideas han terminado por adquirir una existencia propia y separada, convirtiéndose en verdaderos entes ideales, en valores que orientan conscientemente nuestra actuación en todos los ámbitos de la vida social, incluso en aquellos más alejados de la compraventa de fuerza de trabajo, en donde día tras día se siguen originando emprácticamente.

Tenemos pues que intentar comprender la emergencia histórica de esas interpretaciones sociales (hoy en día ya consideradas por nosotros occidentales, un a-priori moral, indiscutido), y para ello necesitamos describir analíticamente algunas de las transformaciones sociales que han acompañado en distintos períodos históricos (al menos en Occidente) la expansión de dicha dominación capitalista. Y digo algunas, porque tan solo nos interesa aquí describir esas transformaciones o efectos sociales del capitalismo en lo que directamente se relacionan con la aparición y generalización de tales valores.

2. Desde el primer momento el capitalismo mostró una pasmosa, nunca antes vista capacidad de enriquecer a quienes lo protagonizaban, desde luego muchísimo más a los que participaban en él comprando la fuerza de trabajo de los demás, pero también, como veremos, aunque mucho menos, a quienes participaban vendiendo la suya propia. Campesinos y marineros ingleses y holandeses, y de otras ciudades y regiones europeas, como del Norte de Italia y Cataluña, de Lisboa y de algunas ciudades alemanas y francesas, observaron digo, muy tempranamente, allá por los siglos XIV y XV, que algunos hombres que procedían de sus mismos estamentos sociales, se hacían inopinadamente ricos, en determinados sectores productivos, como el comercio colonial, la armazón de barcos, la fabricación de armas, la minería, la imprenta, los tejidos, la seda, etc etc Lo más asombroso de todo, lo que más impresionó a la imaginación popular, era que se trataba de unas riquezas que no provenían, como las de los antiguos linajes de nobles y campesinos, de estrategias matrimoniales secularmente calculadas, sino resultado de un método nuevo y enigmático, de eficacia apabullante, que no era otro que el de negocios que (por su rápido crecimiento) obligaban a la contratación de mano 
de obra asalariada, más allá del círculo íntimo de familiares, parientes y vecinos $^{8}$.

Por sus ocupaciones mercantiles, y sus aficiones distintivas (la lectura en privado de la Biblia, la inventiva técnica y la curiosidad científica, los cuadros de paisajes e interiores, los muebles caros y las joyas, los jardines, etc etc), al tiempo que crecían sus negocios a largo de los siglos XVI y XVII, se fueron separando cada vez más, y con toda intención, de los campesinos, artesanos, y marineros, que les recordaban demasiado vivamente sus propios orígenes, pero también repugnando la vida de la nobleza, que por consideración de linaje, no estaba a su alcance, y a la que despreciaban igualmente por improductiva y holgada.

Estos proto-burgueses y burgueses de primera hora, pronto dieron sin embargo con el expediente de calcular también ellos estratégicamente los matrimonios de sus hijas (al parecer, en esto, no tuvieron escrúpulos en seguir el general recetario patriarcal), para consentirlos tan solo con los hijos de los de su clase, matrimonios que bien pronto se distinguieron de los matrimonios campesinos por su mayor disciplina (puritana), pues el heredero familiar no lo era ya de una empobrecida casa de labranza, sino de un floreciente negocio capitalista iy había mucho más que perder!

Reconocemos pues, y ya desde sus primeros momentos históricos, este rasgo que va a acompañar siempre al modo capitalista de acceso a propiedad, que la convierte precisamente en privada, y es que esa apropiación, precisamente por ser resultado de la compraventa de fuerza de trabajo, engendra desde un principio su propia y moderna sociabilidad, construye incesantemente una propia y moderna sub-sociedad, en el interior y en los márgenes de la sociedad más amplia en la que progresa. Las clases burguesas emergentes que la constituyen, nada deben, nada quieren deber a los estamentos antiguos (y aún a las clases burguesas 'venidas a menos'), ya que provienen de un distinto método y origen de apropiación (o del mismo, pero en variedades históricas ya periclitadas). Las clases burguesas no pueden sino despreciar cualquier sociabilidad que no sea la suya propia, la que ellas inventan en cada momento histórico. Bigotry.

A lo largo del siglo XVIII se van concentrando en talleres ad hoc un número cada vez mayor de operarios cada vez mejor organizados, a los fines de su mejor explotación, apareciendo en consecuencia en sus manos herramientas cada vez más especializadas, para el desempeño de su indivisa labor. De este modo, la propia serialización de la fuerza de trabajo va a inventar, a pie de planta, y a perfeccionar luego, en las universidades que financia, las tecnologías y saberes mecánicos, químicos, matemáticos, etc etc que la hacen cada vez más calculable, rentable y expansiva. Comienza entonces la

\footnotetext{
${ }^{8}$ No conocían los nobles ni los campesinos ni los artesanos otro método consuetudinario de adquirir patrimonio que por transmisión (de padre a primogénito varón) de la casa y del oficio familiar, y aún lo que así se transmitía era meramente el usufructo de dicha casa u oficio, un usufructo además familiarmente compartido. No era ese patrimonio familiar una propiedad susceptible de ser comprada o vendida, ni era algo considerado en ningún sentido privativo, esto es: individual
} 
Revolución Industrial, en algunas fábricas de tejidos de Manchester y de Liverpool, donde se aplica por vez primera (en 1787) la energía del vapor al movimiento de los telares, revolución industrial que continua desde entonces su imparable Progreso, pero al que ahora nos hemos acostumbrado como si tal cosa, pues hemos perdido por el camino aquella mirada entusiasta (pero también distante y reflexiva) que provocaba en nuestros bisabuelos.

Algunas empresas familiares contratan entonces a obreros por miles, creando en toda Europa y en Norteamérica legendarias dinastías burguesas: Thyssen, Rothchild, Botin, March, Carnagie, Rockefeller, Ford, etc etc. Los capitales, para hacer frente a las cada vez más sofisticadas tecnologías -acero, hormigón, electricidad, automoción, petroquímica, turismo, prensa etc. etc.-, que obligan a contratar cada vez mas escolarizados y rentables asalariados, ante esas tremendas inversiones, no tienen más remedio que asociarse, bien por proximidad parental o vecinal, o en Bolsa, de un modo cada vez más anónimo, abstracto y jurídico. ${ }^{9}$

Centenas de miles, millones de campesinos literalmente, abandonan entonces sus campos, atraídos por 1los empleos que ofrecen las fábricas que se concentran en las ciudades, abducidos por la espiral re-inversora de los capitalistas, que saben en todo momento calcular los salarios precisos para hacer que los hombres abandonen la agricultura. Y no solo ellos, sino también sus mujeres y niños encontrarán trabajo en esas fábricas, cuyos salarios administrarán sus maridos y padres, porque ellos también saben, cuando les favorece, aprovecharse del dicterio patriarcal.

Marx enfatizó las expropiaciones campesinas legisladas sistemáticamente por los Comunes ingleses a lo largo del siglo XVIII, es decir, la proletarización campesina engendrada en la Isla por las llamadas 'enclosures', y es cierto. Pero nada de eso se produjo (por lo menos no tan abiertamente) en Francia, en Cataluña, en el Norte de Italia, y en otras partes de Europa, y sin embargo también en ellas se fue vaciando el campo, a lo largo del siglo XIX.

No, si queremos comprender cabalmente la naturaleza del capitalismo, su tremenda capacidad de atracción y fortaleza interior, no podemos juzgarlo tan solo económicamente, por la apropiación de renta y de bienes que concede a los que se incorporan a él, aunque lo hagan comerciando tan solo con su fuerza de trabajo. Eso está ahí, y eso es importante, tal vez incluso definitivo, pero no sólo está eso. Porque esos campesinos que por doquier abandonan el campo a cambio de la industria de la ciudad, perciben también un nuevo mundo social, emergente e imparable, contra el que nada pueden la vieja agricultura y demás artesanías, y quieren naturalmente apostar por un futuro que será fatalmente industrial, y que será fatalmente el de sus hijos, que por fuerza nacerán en él, y a los que quieren por tanto dotar de las armas sociales y morales que son propias del mismo:

"Por otro lado, el comerciante, que busca una ventaja tangible y no obstante abstracta como propósito real y racional de su actividad aparte de su actividad

\footnotetext{
${ }^{9}$ Cada vez más escolarizados, rentables y sumisos asalariados: "Si el capital enrola a la ciencia, la mano rebelde siempre aprende a ser dócil" Ure, 1830, citado por Sorel (2005: 380).
} 
propia, es, en este sentido, el primer ser humano libre y pensante que aparece en el desarrollo normal de la vida social. Se encuentra aislado, tanto como puede, de todas las relaciones, deberes y prejuicios necesarios. Se encuentra libre de las ataduras comunitarias, cuanto más libre esté de ellas, mejor para él." Tönnies (1979: 86).

Sí, Ferdinad Tönnies, el campesino Tönnies, y en general todas las mentes sociológicas más preclaras, que coincidieron con esa primera hora industrial del capitalismo, no se dejaron engañar (como tampoco lo hizo el sentir popular) y reconocieron en el capitalismo un factor de prosperidad y de liberación personal y social, tal vez lleno de riesgos y de problemas, pero en cualquier caso también una oportunidad histórica que no iban a dejar escapar.

Porque el capitalismo trae consigo desde el primer momento, para bien y para mal, un nuevo modo de sociabilidad, un nuevo modo de hacer sociedad, si se quiere (como gustaba decir Don Julio Camba) un nuevo modo de humanidad. Cualquier otra descripción se quedará corta, será incompleta, y no le hará justicia. $Y$ esa justicia nos es necesaria, porque queremos superarlo, porque queremos dejarlo atrás.

Pero la acumulación de capital sigue su impulso exponencial, no encontrando en las guerras sino oportunidades para su renovado relanzamiento, y después de la Segunda Guerra Mundial experimenta un nuevo acelerón, esta vez haciendo un uso pacífico de las tecnologías inventadas por todos los bandos, los que ganaron y los que perdieron la guerra, tecnologías que son aplicaciones cada vez más directas y perfeccionadas de las Ciencias Físicas, como la TV y sus derivados, la informática, la genética, la energía nuclear, la óptica, el espacio, la cuántica computacional, etc etc. Tecnologías tan caras que obligan para su adquisición al agrupamiento (por medio de la Bolsa) de enormes capitales anónimos, en sociedades capaces de producir y servir en todo el planeta. Tecnologías supersofisticadas que exigen también de aquellos individuos que han de manejarlas el aprendizaje (prolongadísimo en años) de los correspondientes lenguajes especializados, altamente formalizados, como son las matemáticas, contabilidades, legislaciones, etc etc Aparecen así en los países occidentales (u occidentalizados), donde residen las sedes centrales (fiscales) de esas empresas multinacionales, unas amplísimas clases medias, nutridas de ingenieros, abogados, médicos, publicistas, periodistas, bioquímicos, cineastas, deportistas, economistas, pilotos, arquitectos, diseñadores, etc etc $Y$ como el salario ha de pagar el tiempo socialmente necesario para la formación académica y laboral de tales profesionales, se produce en esos países una elevación general del consumo de bienes y servicios, un nivel de consumo desconocido, por su extensión y profundidad, en cualquier otro período de la historia humana (esos asalariados universitarios pueden llegar a constituir el 30-35 \% de los países ricos).

Prácticamente la mitad, o tendencialmente al menos la mitad, de esos empleos especializados van a ser ocupados por mujeres, pues allá por los años 1950' el capitalismo ha despoblado ya prácticamente el campo, no quedando casi campesinos a los que sacar de la agricultura (convertida ella misma en un sector más del mercado, mecanizada y transgénica), por lo que tiene que 
proceder a contratar masivamente mano de obra femenina. Mujeres académicamente y laboralmente tan preparadas como los hombres (sino más), que por millones se incorporan al trabajo asalariado, en condiciones tendencialmente igualitarias a las de ellos (tendencialmente, porque como siempre, el capitalismo sólo descarta las viejas discriminaciones sociales cuando dejan de serle rentables).

Pero todavía, cuando son muchos los nacionales en edad de trabajar que ya están efectivamente trabajando, y el paro disminuye, y empiezan esos nativos a ganar capacidad de negociación en serio de sus salarios, los políticos no tardan en oír las súplicas angustiadas de los empresarios, siempre quejosos de los márgenes de explotación que disfrutan sus colegas vecinos, por lo que esos políticos, y sus administraciones, abren entonces disimuladamente las fronteras, para deja entrar a millones de inmigrantes pobres de otras naciones (mejor sin papeles), restituyendo así de golpe los salarios a sus niveles rentables. Fue de este modo que España se convirtió en el curso tan solo de los últimos 10 años en un país plagado de mileuristas.

3. Se produce de este modo contemporáneamente, en estas sociedades nuestras articuladas en torno al mercado (por la prioridad vital que todos damos a nuestra profesionalización), una tendencia muy efectiva a la igualación social, entre otras cosas por la condición cada vez más genuinamente meritocrática del sistema educativo, en el que las mujeres occidentales están obteniendo últimamente mejores resultados que los hombres. Y esos curricula escolares segmentan en bastante el mercado laboral, y en mucho más (casi determinan) el acceso al funcionariado. Por vez primera en la historia de las sociedades humanas (hasta ahora regidas por cualesquiera parentescos), las mujeres se van haciendo dueñas del resultado de su trabajo, como consecuencia de la condición privada o individual que hemos visto caracteriza (y singulariza) a la apropiación capitalista. Y es este un mérito importantísimo del capitalismo, un rasgo estructural que le es exclusivo, que va perfeccionando en su expansión, y que nadie puede discutirle.

Además, esa relativa igualación que se está produciendo en las sociedades occidentales, es lo que mejor sirve para caracterizarlas (sociológicamente hablando), pues se están convirtiendo en auténticas sociedades de clases medias. Porque aunque en ellas los hombres y mujeres que protagonizan los empleos más tecnificados no representan quizá más allá de un 25-30\% del total de la población, se convierten sin embargo en el modelo de sociabilidad telefilmada, que imitan los otros estratos sociales, y no sólo las clases más populares (apegadas todavía a trabajos manuales) sino también incluso las clases más empresariales, que también mimetizan en sus gustos y comportamientos los de esas clases medias... aunque procurando, eso sí, realizarlos con un nivel de consumo distintivo. ${ }^{10}$

\footnotetext{
10 "Percival y Paul Goodman en su estudio Communitas (1960) han retratado, en forma brillante e irónica, la vida de una sociedad de consumo en el futuro (...) Proponen que, para planificar una expansión de la demanda, la sociedad necesita un análisis del 'Consumo Eficiente', análogo -aunque invirtiendo los términos- al concepto de la 'Producción Eficiente' de Veblen. Cuando Veblen exaltó la laboriosidad, el interés por la técnica y otras virtudes productivas de los ingenieros en contraposición con las cualidades o costumbres restrictivas de los capitalistas, estaba pensando todavía en función de una necesidad de mayor cantidad de
} 
4. Esa relativa (pero efectiva) igualación de oportunidades profesionales (y vitales) que se presentan a todos nosotros los que pertenecemos a las clases medias creadas por el capitalismo organizacional, lleva implícita consigo una tendencial capacidad de elección entre ellas, que abre de este modo delante de cada uno enormes posibilidades de diseño de su propia trayectoria social, lo cual constituye otra gloria no menor de este sistema capitalista. Porque si bien todo sistema social concede una cierta autonomía a los individuos que participan en él -como la que tiene el futbolista en el campo para improvisar los movimientos que imprime al balón, o el conductor que decide cuando y donde se incorpora o abandona la red viaria, o la que tenían antaño las mujeres campesinas para elegir (hasta cierto punto) marido, etc etc En esto de las libertades propias, el capitalismo es particularmente diversificado y versátil, por esa su condición sistémica que tiene de desbordar constantemente sus propias fronteras tecnológicas y productivas, con lo que amplia exponencialmente la división social del trabajo (Durkheim) y con ella las oportunidades laborales de todos sus subordinados.

bienes. 'Pero', continúan los Goodman, 'el hecho es que hace ya más de dos décadas, no ha sido la escasez de producción lo que ha mantenido a los hombres en una sujeción política (por muy irónico que resulte, ha sido, en parte, la inseguridad de la llamada sobreproducción); económicamente, ha sido precisamente la debilidad -y no la fuerza- de las actitudes típicas del consumo: emulación, ostentación y el despilfarro completo lo que ha puesto un límite a la productividad, que constituye el ideal de un economista. Sólo los instintos desencadenados por la guerra, bajo las condiciones modernas, han bastado para proporcionar una salvación económica.

En tal caso, permítasenos invertir el análisis y proponer la forma como, incluso en épocas de paz, los hombres pueden despilfarrar de la manera más eficiente posible. La ciudad que ideamos de acuerdo con este principio no es solamente una solución teórica para la ciencia económica que parece haberse adoptado como sistema oficial, sino que emana también de las demandas morales existentes de las personas que se han aglomerado en metrópolis como la ciudad de Nueva York.'

En la sociedad de consumo que visualizan los Goodman, la producción es sólo un medio puesto al servicio de los fines del consumo y, por consiguiente, desaparece la satisfacción en el trabajo. De acuerdo con esto, el trabajador concentra todas sus exigencias en la obtención de condiciones laborales adecuadas, pocas horas de trabajo y salarios elevados, de tal manera que pueda alejarse apresuradamente del empleo contando con suficiente tiempo, poder adquisitivo y energía, para perseguir sus metas como consumidor. Dichas metas sólo puede alcanzarlas 'en una gran ciudad. Y el impulso principal hacia los bienes mencionados no es individual sino social. Es la imitación y emulación que resultan de la apresurada demanda. Tal vez, en un principio, lo que satisface a los habitantes de la ciudad son las comodidades para las masas -las cuales pertenecen a la imitación mutua-, pero al final, son los lujos, porque éstos pertenecen a la emulación, a lo que Veblen solía llamar, la imputación de superioridad... Todo esto sólo puede llevarse a cabo en una gran ciudad... El corazón de la ciudad en que existe una demanda eficaz en proceso de expansión es la tienda o gran almacén de departamentos... En él se encuentran disponibles todas las cosas de acuerdo con los deseos del consumidor, exhibidas de modo que despierten el deseo. Las calles son corredores del gran almacén; porque el trabajo de la gente no debe aislarse de su significado cultural.'."

Potter (1965: 232-234) [cursivas del autor].

Porque en sociedades que tendencialmente no admiten ya las antiguas disposiciones estamentales, no cabe ya otra manera de distinción social entre clases que esa de consumir (algo que los verdaderos empresarios siempre han despreciado, considerándola una manifestación de debilidad política, como en efecto lo es).

Para esto del consumo, y en Sociología, los autores clásicos de referencia son Veblen (2005) y Simmel (1904). 
Y digo subordinados, porque se trata tan solo del aprovechamiento de las libertades propias del sistema, aquellas que residen allí donde la Ley guarda silencio (Hobbes), y cuyo uso en modo alguno implica la desaparición de tal Ley, sino su más acabado cumplimiento. Es una pena que estos chicos y chicas, estos juniors y seniors tan esforzados y talentosos ellos, que pueblan las elites organizacionales del capitalismo actual, en vez dedicarse a buscar su particular ventaja, no se decidan a utilizar sus reconocidas habilidades negociadoras y tecnológicas, para ir creando actividades que atemperen poco a poco la explotación recíproca, produzcan objetos duraderos, ofrezcan también repararlos, atiendan dignamente a sus clientes, y cobren por todo ello lo que les suene razonable, sin querer hacerse ricos.

Pero dejémonos de ensoñaciones vanas. Lo cierto es que esas oportunidades que ofrece el capitalismo son utilizadas por cada uno para lograr sus aspiraciones de medro en el sistema, cualesquiera que ellas sean, cada cual según sus posibilidades, inclinaciones, y gustos. Por lo que vamos adquiriendo una gran habilidad para calcular rigurosamente lo que aceptamos y lo que descartamos, lo que nos conviene o nos perjudica, sometiendo todas nuestras relaciones sociales, académicas, profesionales, e incluso sentimentales (aunque esta últimas un tanto contradictoriamente) a una constante decisión o encrucijada, que nos va separando, que nos va aislando cada vez más de los demás:

"Desde este punto de vista, la vida se concibe y se lleva como negocio, esto es, con la finalidad o concepción definida de obtener una felicidad imaginaria como propósito último. Por supuesto resulta entonces posible formar conceptos y establecer reglas que representan y demuestran el método mejor para alcanzar ese fin y resultan de tal suerte que ha de ser entendida y aplicada por cualquier persona capaz de un razonamiento lógico que, en realidad, se ha de llevar a cabo por todos y en cualquiera de las actividades. La naturaleza de esta teoría se hace más evidente en la mecánica. La mecánica no es más que matemática aplicada. Las matemáticas no son sino lógica aplicada. El principio de la mecánica aplicada puede formularse en términos generales como sigue: obtener el mejor resultado posible con la menor inversión posible de energía o de trabajo. El sentido de este principio, empero, cuando se considera relacionado con cualquier cometido dirigido a un fin definido, puede expresarse de la manera siguiente: el fin debiera obtenerse de la forma más perfecta posible con los medios más cómodos y sencillos posible. O bien, cuando se refiere a un negocio que se fomenta con dinero: el mayor beneficio posible con el menor costo posible, o el beneficio neto más elevado posible. Y si este principio se aplica a la vida como negocio: la mayor cantidad de placer o felicidad con la mínima cantidad de dolor, esfuerzo perturbación, el mínimo sacrificio de bienes o de energía vital (mediante el trabajo)." Tönnies (1979: 165-7).

Si, a medida que el cálculo curricular de cada uno y de todos se hace más y más riguroso (y algunos hay que tienen una agenda a varios años vista) mayor serialización de esos hombres y mujeres mercantilizados, individuos 
estandarizados y aptos para su intercambio en los empleos unidimensionales que les ofrecen las poderosas organizaciones capitalistas y funcionariales.

5. Por otro lado, el pacto patriarcal de antaño, que regía sin excepción todas las sociedades occidentales en tiempos anteriores a esta dominación, aquel que forzaba las voluntades del hombre y de la mujer hasta conseguir aunarlas en la crianza de un primogénito varón, es ahora claramente disfuncional a la mercantilizada existencia de nuestras clases medias. ¿Pues para que ha de querer ahora el hombre un heredero de su casa y de su oficio si su trabajo se desarrolla en una organización empresarial o funcionarial cuya continuidad en nada depende del logro de tal heredero? ¿Y porqué ha de querer la mujer tener un hijo, ahora que su personalidad social no depende ya del ejercicio de la maternidad, sino que aún ha de resentirse en mucho de tal ejercicio? No es que el capitalismo prohíba dicha crianza (como contaba Huxley en Un Mundo Feliz), pero la convierte en una opción meramente sentimental (y a contracorriente del mecanismo social) con lo que se va volviendo cada vez más precaria, cada vez más anómica. Nuestros domicilios se convierten entonces en una mera yuxtaposición de individuos, con las más novedosas composiciones.

En fin, que todas las condiciones sociales que trae consigo la expansión entre nosotros de negocios capitalistas cualesquiera, y que hemos venido comentando -a saber: una general apropiación individual, una tendencial igualación de oportunidades, y de la capacidad de elegir entre ellas- pueden sumarse diciendo que nuestras sociedades occidentales están experimentando un fuerte proceso de individuación, pues todos los que vivimos en ellas, para poder sobrevivir, nos vemos obligados a priorizar ante todo nuestra vida profesional, toda nuestra vida social ha de girar cada vez más en torno al mercado. Algo realmente desagradable. ${ }^{11}$

6. Pero esa individuación galopante, es poco más que la conciencia personal que precisa desarrollar el individuo para el logro de su supervivencia en sociedad, un movimiento ideacional sí, pero apenas inmanente que acompaña a la compra y venta de fuerza de trabajo. Esa individuación, decimos, es poco más que la conciencia que pronto adquiere el individuo de que para sobrevivir en el capitalismo ha de convertirse él mismo (y ella misma) en una empresa. Una empresa unipersonal. Un movimiento ideacional forzado a reconocer la condición individual de la contratación laboral, y que por eso mismo está demasiado cerca de su concomitante movimiento represivo (el despido), como para llegar a levantar el vuelo, a convertirse en un ideal que pueda ser objeto de veneración social.

Ese paso: la conversión de un simple procedimiento necesario de supervivencia social, en todo un principio de excelencia o de virtud moral; ese paso, capaz de presentar esa fatal individuación como si fuera libre

\footnotetext{
11 Súbditos entusiastas de esa sociabilidad capitalista abstracta, en tanto que vinculados casi solo (desde un punto de vista estructural) profesionalmente, nos vemos llevados a citarnos compulsivamente y encontrarnos forzosamente a través de móviles, pantallas, redes telemáticas, y todo tipo de cachivaches e implantes cibernéticos, útiles inventados en y para la expansión de esa sociabilidad capitalista, cada vez más virtual.
} 
individualismo, exige, a quienes están destinados a darlo, el salto a otra posición estructural diferente dentro de la sociedad, el alejamiento del mundo del trabajo, el alejamiento del mundo de la empresa, y el acercamiento y la adscripción al mundo del gobierno y de la administración, y particularmente al mundo de las asambleas representativas, de los parlamentos donde día tras día se argumenta y se legisla la sociabilidad general concomitante con el capitalismo.

Como sociólogos podríamos intentar aquí la descripción sistemática de esa posición estructural que distingue a las asambleas representativas en relación o con respecto a las prácticas productivas y de crianza, consideradas privadas en nuestras sociedades occidentales, y tal vez en algún momento tengamos que hacerlo, en este mismo escrito (aunque de manera tangencial).

Pero constituye un camino más expeditivo y directo rastrear en lo posible la historia de la primera y más original y verdadera de esa gobernación por asambleas, su historia pionera en relación precisamente con la expansión de la ciudadanía capitalista hoy en día entre nosotros dominante. Nos estamos refiriendo naturalmente a la historia del parlamentarismo en Inglaterra.

Invadimos así el territorio de los historiadores, y que nos perdonen tal osadía, pues lo hacemos con desconocimiento de las cautelas metodológicas e historiográficas que ellos han venido perfeccionando desde hace siglos. Entramos a analizar el pasado de sociedades que no son las nuestras, y lo hacemos tan solo aprovisionados con unas pocas (y apresuradas) lecturas de historiadores, y con las armas de la Sociología, afinadas sobre todo en el estudio y para el estudio de nuestros sistemas sociales contemporáneos. No deberíamos hacerlo, pero sabemos que por mal que lo hagamos, mucho nos va a aclarar sobre la dominación capitalista el conocimiento de los orígenes históricos de su administración parlamentaria.

"La Gemeinschaft (comunidad) es antigua; la Gesellschaft (asociación) es reciente, en tanto que denominación y fenómeno social. Esto ha sido reconocido por un autor que, por cierto, ha enseñado la ciencia política en todos sus aspectos sin penetrar en sus fundamentos. 'El concepto de Gesellschaft (sociedad) en un sentido político y social -dice Bluntschli (Staatswörterbuch IV)- halla su fundamento natural en las costumbres y las ideas del tercer estado. No se trata realmente del concepto de pueblo (VolksBegriff) sino del concepto de tercer estado... Su Gesellschaft se ha convertido en origen y expresión de opiniones y tendencias comunes... Doquiera que la cultura urbana florezca y alumbre, aparecerá la Gesellschaft como órgano indispensable. En el campo apenas se sabe nada de esto'." Comunidad y Asociación, Ferdinand Tönnies, 1888

\section{English break through}

Consideramos imprescindible para comprender la apabullante eficacia de la sociabilidad capitalista, conocer el papel que en su emergencia y consolidación en Occidente, tuvo el gobierno y la administración de Inglaterra, desde muy antiguo, por medio de 'Rex in Parlamento'. Es cierto que otros reyes europeos 
convocaron en épocas medievales parecidos parlamentos, pero sólo los reyes ingleses (por circunstancias históricas singulares) se vieron forzados a convertirlos en el procedimiento habitual de su gobierno. Y esto, ya digo, debe ser tenido como una de las causas más directas del éxito del capitalismo, no ya en Inglaterra, sino también en su aventajada discípula norteamericana, y aún entre nosotros, el resto de sus vecinos occidentales.

Nos proponemos aquí sobre todo llamar la atención de los historiadores y politólogos españoles, portugueses e iberoamericanos, sobre la urgencia de estudiar el vínculo (para nosotros evidente) entre sociabilidad capitalista y gobierno por asambleas representativas, y estudiarlo precisamente allí donde y cuando históricamente se inventó y fue primero construyendo, de una manera tan perfeccionada y ejemplar que sirvió luego como referencia para todas las otras sociedades occidentales.

Somos sociólogos, y sabemos que no está a nuestro alcance (al alcance de nuestra formación) el intentar estudiar como es debido esas sociedades inglesas y norteamericanas del pasado (pues son los historiadores quienes han de hacerlo). Y que tampoco dominamos las categorías analíticas que (específicamente) viene construyendo la Ciencia Política para comprender cualesquiera instituciones y filosofías de gobierno, también las democráticas. Pero aunque nuestras interpretaciones (sociológicas) no tengan ningún valor historiográfico o politológico, son muy útiles y necesarias a los fines (sociológicos) que aquí nos proponemos. Porque no concebimos esas sociabilidades capitalistas sin las asambleas representativas con que, en su madurez, se gobiernan.

\section{Inglaterra Normanda}

Después de la batalla de Hastings (1066), Guillermo, Duque de Normandía, se proclamó Rey de Inglaterra con el título de Guillermo I, y procedió a la sistemática laminación de la nobleza nativa. Repartió 5.000 feudos, grandes, medianos y pequeños entre sus Grandz (o barones) y sus knights (o caballeros). Sustituyó por obispos y monjes normandos no solo a toda la cúpula alta y mediana de la Iglesia Católica inglesa, sino también a todos los curas de las parroquias. Impuso el francés como idioma oficial en todas las instituciones feudales. Y para evitar problemas penales y de orden público en los condados, creó específicamente, a mayores de los tribunales señoriales civiles correspondientes o Hallmotes, otros tribunales presididos por el sheriff o por jueces reales itinerantes, a los que llamó View of Frankpledge, y que actuaban cada 6 meses. Esos tribunales reales forzaban a los jóvenes cuando entraban en la edad adulta a agruparse de 12 en 12, formando tithings, de modo que cada uno de ellos era considerado responsable del comportamiento penal de todos los demás ${ }^{12}$.

12 "Frankpledge. System by which each member of a tithing was responsible for every other. XV (fraunciplegge). - Law Latín franciplegium, latinization of Anglo-Norman frauncplege, formed on franc FRANK + plege PLEDGE..." Onions (1985). 
Los View of Frankpledges desarrollaban sus sesiones en francés, recurriendo a intérpretes en las pruebas testificales, y tenían una gran preocupación formal. Los presidentes no actuaban ni como juez ni como parte, limitándose a comprobar la asistencia de las personas concernidas (obligatoria), garantizar los pasos del procedimiento, la legitimidad de las partes, y el cumplimiento efectivo de la sentencia (dictada por el jurado):

"Great stress was laid upon strict verbal accuracy in pleading: the demandant had to make his plea according to the customary form, and the defendant had to deny the plea word for word... The pleadings were treated as if the were charms which would lose their virtue if changed in the least particular. Even in England in the Middle Ages, before these lowly hallmotes, many a plea was lost because a man did not repeat the formulas correctly. Indeed, in their insistence on strict verbal propriety, the hallmotes were more archaic than the royal courts." Homans (1975: 315-6)

Los normandos supieron aprovechar, para sus propios fines disciplinarios, algunas instituciones como el jurado, tal vez anteriores en la Isla a su dominio. Pero los jurados de los View of Frankpledges estaban formados exclusivamente por notables normandos, pues era un principio básico de esos tribunales el que nadie podía ser juzgado por alguien de un estamento inferior.

Toda la vida institucional anglo-normanda, de arriba abajo, laica o eclesiástica o judicial o cortesana, en los tres siglos que siguieron a la Conquista de Guillermo, se realizaba exclusivamente en francés, y en este idioma (o en latín) aparecen escritas todas y cada una de las Actas (o rolls) de cualesquiera instancias feudales. No se ha encontrado ningún Acta escrita en inglés antes del siglo XIV, por increíble que esto pueda ahora parecernos.

Las escuelas y universidades desterraron el inglés de sus aulas y claustros, pues enseñaban el latín desde el francés (no desde el inglés). Ese idioma nativo se subdividió en innumerables dialectos locales, pues quedó condenado a sobrevivir únicamente en la expresión oral de campesinos y artesanos (y aún entre estos últimos, en las ciudades, amenazado por el prestigio del francés).

Por otro lado, los Tenentes-in-Chief, o grandes barones del reino, cuando aconsejaban al Rey en la Curia Regis o Consejo Real, sobre los asuntos propios del gobierno o de la administración, tales como la declaración de guerra y paz, la acuñación de moneda, la judicatura superior, el establecimiento y cobro efectivo de impuestos, la emisión de correos, edictos y legislaciones, etc. etc. lo hacían desde luego únicamente en francés. ${ }^{13}$

La llamada Law of Englishry, dictada a lo poco de la Conquista, establecía la presunción de culpabilidad de un inglés en cualquier homicidio o asesinato de un normando. Es más, si un desconocido aparecía muerto por causa violenta, se le presumía normando, y la corte del distrito (Hundred) tenía que imponer la correspondiente sanción sobre los vecinos, salvo que demostrasen que la victima era de ascendencia inglesa.

${ }^{13}$ En todo este epígrafe y sucesivos soy deudor del excelente libro del profesor Iglesias Rábade (1992). 


\section{Carta Magna}

Pero en una perspectiva histórica, bien pronto los reyes normandos y sus sucesores angevines mostraron una recurrente debilidad ante sus barones, mucho mayor que la que tenían los otros reyes continentales ante los suyos, seguramente porque la estructura feudal en Inglaterra había sido, por así decirlo, diseñada, esto es: impuesta de un golpe por la espada, tras la Conquista, y no gestada a través de los siglos a partir de un desarrollo tradicional, orgánico, del antiguo vasallaje anglo-sajón.

Además en 1204, el rey Juan pierde el ducado de Normandía, que es ocupado por el rey de Francia, recibiendo desde entonces el sobrenombre de Juan Sin Tierra, y orienta todos sus desvelos a la reconquista de las posesiones perdidas. Disminuido ante sus barones, irritados por la pérdida de sus posesiones en el Continente, y por los reiterados fracasos militares del rey, los tenentes-in-chief empiezan una prolongada conspiración en contra de Juan, para forzarle a compartir el gobierno y la administración del reino, conspiración que desencadena una guerra civil, que obliga a John en Junio de 1215 a firmar un tratado de paz con sus barones, tratado que hoy conocemos como la Carta Magna.

Entre otras cláusulas -algunas eclesiales, otras referidas a la ciudad de Londres, o bien fiscales o jurídicas, que casi convertían al rey en un barón más, pues lo sometían también a las leyes del reino, etc. etc. - nos llama la atención sobre todo la última de dicha Carta, que dice así:

"61. Since, moreover, we have granted the aforesaid things for God, for the reform of our realm and the better settling of the quarrel which has arisen between us and our barons, and since we wish these things to be enjoyed fully and undisturbed, we give and grant them the following security; namely, that the barons shall choose any Twenty-Five barons of the realm they wish, who with all their right are to observe and mantain... the peace and liberties which we have granted and confirmed to them by this our present charter; so that if we... offend against anyone in any way or transgress any of the articles of peace, and the offence is indicated to four of the aforesaid twenty-five barons, those four barons shall come to us... and bring it to our notice and ask that we have it redressed without delay. And if we ... do not redress the offence within forty days from the time when it was brought to our notice... the aforesaid four barons should refer the case to the rest of the twenty-five and this twenty-five with the commune of the whole land shall distress and distrain us in every way they can, namely by seizing our castles, lands and possessions... until in their judgement, amends have been made." Jones (1971: 137-8).

Es decir, que los barones, en el futuro, y según su exclusivo criterio colegiado, podrían -legalmente- recurrir al uso de la fuerza en contra del rey, pudiendo contar para ello, si así lo considerasen necesario, 'with the commune of the whole land', esto es, con todas las fuerzas y estamentos a su alcance.

Dada la importancia que tenía la letra escrita en la formalista Inglaterra normanda y angevina, no ha de sorprendernos que el rey muriese sin aceptar 
ni cumplir en ningún momento lo que había firmado, prolongándose esa misma guerra civil, u otras parecidas, durante el largo reinado de su sucesor, Henry III (1216-1272), que tampoco dio nunca por bueno tal tratado.

La pérdida de Normandía había producido, ya en tiempo de Juan, sucesivas oleadas de artesanos y comerciantes franceses, que se instalaban en los puertos y ciudades inglesas, particularmente Londres. Esto ocurrió todavía más a raíz del casamiento de Henry III con Eleanor de Provenza en 1236, pues el rey entonces procedió abiertamente a destituir a muchos barones anglonormandos de sus altos cargos institucionales, civiles y eclesiásticos, colocando en su lugar a significados nobles procedentes del sur de Francia, y entre ellos destacó en las preferencias del rey el caballero cruzado Simon de Montforte, al que casa con su hermana. Una parte de la nobleza se afrancesó todavía más, la otra en cambio reaccionó violentamente contra el favoritismo extranjero del rey, sobre todo después de su fallida aventura caballeresca en Sicilia (1258):

"On the day of St. Hilary a countless multitude of nobles... came to London at Westminster... replies with indignation that they were oppressed on all sides... paying now the twentieth, now the thirtieth and now the fiftieth part of their property, and they declared that it would be unworthy of them, an injurious to them, to allow a king, so easily led away, who had never repelled or even frightened one of the enemies of the kingdom, even the least of them, and who had never increased his territories but rather lessened them, an placed them under foreign yoke, to extort so much money, so often, and by so many arguments, from his natural subjects as if they were slaves of the lowest condition, to their injury and for the benefit of foreigners." ${ }^{14}$

Todo esto fue dando pie a una nueva conspiración de barones en contra de la autoridad real, a la que se añadió el propio Simón de Montforte, eventualmente enemistado con el rey, que tanto lo había favorecido, y algunos prelados de la Iglesia Católica, encabezados por el influyente obispo de Lincoln, Robert Grosseteste, y algunos profesores de universidades, como Adam de Marsh, que enseñaba en Oxford. La causa común que los unía era desde luego la recuperación de los privilegios y cargos que les habían sido usurpados por la política pro-francesa de Henry.

La victoria de los barones en Lewes (1264) obliga al rey, hecho prisionero junto a su hijo Edward durante la batalla, a aceptar las famosas Provisiones de Oxford, que otorgaban el poder efectivo a Simon de Montforte. El obispo Grosseteste, verdadero cerebro de la rebelión, anima a Montforte a legitimar su gobierno (que se ejerce en nombre del rey) convocando sucesivos "parlamentos", pero por vez primera no solo se convoca a nobles y clérigos, sino también se requiere la presencia de 2 knights por cada condado, y de 2 burgueses elegidos por las ciudades y burgos más importantes.

\footnotetext{
${ }^{14}$ Fragmento (traducido del latín) de la Crónica Majora, de Mathew Paris, siglo XIII, citado por Iglesias Rábade (1992: 53).
} 
Posteriores disensiones internas de los barones rebeldes, y la muerte de Montforte en el campo de batalla, restituyen a Henry en su efectivo poder, y conducen al Dictum de Kenilworth (1266), que anuló las Provisiones de Oxford, pero en las que también el Rey supo aceptar algunas de las reivindicaciones de sus barones.

\section{Rex in Parlamento}

Edward I (1272-1307) parece comprender desde un principio que los experimentos parlamentarios de Montforte podrían serle útiles para reforzar la maltrecha autoridad de la Corona, y en 1295, cuando convoca el Parlamento, no solo llama, según costumbre, a los miembros de su Consejo Privado, por un lado, y a los Barones y Obispos, por el otro, sino que también escribe a los sheriffs pidiéndoles envíen 2 knights en representación de cada condado, y también 2 burgueses por cada ciudad y burgo de importancia

"with full and sufficient authority on behalf of themselves and the community... to do whatever shall be ordained by common counsel."

A la vista de esto, muy pronto los Seigneurs et Prelatsz cogen la costumbre de reunirse por su cuenta, en una habitación separada, dejando a los Chevaliers y Burgesses reunidos en otra, originándose así el llamado Parlamento Modelo, porque su modo de convocatoria y composición se mantendría duraría siglos. En la primera Casa, la de los Lords, se personan los tenentes-in-chief, laicos y eclesiales, mientras que en la segunda, la de los Comunes, se sientan los que representan a los condados y ciudades.

De este modo el Rey se obligó a hablar o parlamentar, y al hacerlo, obligó también a sus díscolos barones, y a todos los súbditos de su reino. Y ahora sí que todos ellos (por vez primera) merecen el nombre histórico de ingleses.

Fascinante, asombroso artefacto político, éste Rex in Parlamento, que busca y logra al fin saturar las sangrantes heridas de la precaria sociabilidad feudal anglonormanda, pacificando un siglo de luchas civiles. No podría haberse concebido, y mucho menos logrado, sin la experiencia acumulada por notables y comunes en los jurados de toda instancia que atravesaban de arriba a abajo, y de Este a Oeste, la vida local anglonormanda. Miles de jurados prepararon durante siglos este Parlamento.

Pues cuando uno se asoma, siquiera un poco, a los procedimientos tentativamente establecidos, para que por su turno, hablen entre sí, esos actores que protagonizan esos primeros Rex in Parlamento ya completos, comprende inmediatamente que su gran fuerza reside precisamente en el cuidado exquisito que en todo momento tuvieron (iy tienen!) por la formalidad o legalidad de dichos procedimientos.

Y decimos procedimientos, porque ya desde sus comienzos, en el siglo XIV, los había de todo tipo: peticiones singulares (parciales, de una parte del reino), e incluso de una particular persona, elevadas al Consejo Real, por algunos de los

\footnotetext{
${ }^{15}$ ENCYCLOPAEDIA BRITANNICA ON-LINE (2010): Article: The growth of Parliament
} 
Comunes, actuando estos tan solo como meros emisarios. Peticiones por parte del Rey a todo el Parlamento reunido, para imponer nuevos impuestos, para sufragar guerras, cubrir necesidades de la ciudad de Londres, etc. etc. Pero sobre todo, y con el tiempo, se desarrollaran peticiones llamadas (por su objeto) comunes, ya que buscarán beneficiar y fortalecer a la totalidad del reino:

"Ancient Petition in the Public Record Office, n' 3808 (1297-1307 ?), from 'les bones gentz de sa terre', concerns forfeiture of wools in 25 Edward I. In $n^{0}$ E216 (1302) 'se est mustre pur son people' that sheriffs indict men maliciously, with special reference to the sheriff of Salop, and the response takes for granted that the county is the one concerned. No 5435 (c. 1319) is a protest by 'la Communalte du Roialme Dengleterre' against 'les overoures des Chapeus en Fletestrete de la Cité de Loundres'. No 3955 (1322 ?) proceeds from 'les Chivalers des Countez et tote la Commune de sa terre' and asks that justices shall be assigned to take fines from the adherents of rebels. In Chanc., Parl. and Council Proc. 8/22 (c. 1324 ?) 'la Comminaulte de sa terre' petitions that executors shall be compelled to render account. And in Chanc., Parl. and Council Proc. 4/20 (c. 1316-24 ?) 'la Comunialte dengleterre' complains that sheriffs and under-sheriffs takes fees, robes, and pensions." Rayner (1941: 198).

Estas últimas, las Communes Petitions, que se irán decantando como la tarea más acorde a la condición representativa de los Comunes, seguirán un curso diferenciado de las Singuleres Petitions:

"Totes les peticions einz ces houres mises par la commune en parlement ount este respondues pleinement devant le departir des ditz parlamentz. Et quant a singulares peticions ore baillez a yee parlement, nostre seigneur le Roi voet qe les auditurs ore assignez pur les trier les trient et terminent avant leur departir de mesme le parlement. » Rayner (1941:198) [cursivas nuestras]

siendo elevadas (las Commune) al Consejo privado del Rey, que pedirá en ocasiones, cuando lo considere oportuno, a la Cámara de los Chevaliers y Burgesses, que escojan a algunos de entre ellos para que se reúnan con los Seigneurs por Él nominados, a los efectos de 'Q'eux s'avisent coment l'amendement se purra faire." Rayner (1941: 557).

Pero en asuntos humanos nadie tiene la última palabra, ni puede proclamar el fin de la historia, y precisamente por entonces (siglo XIV) empieza a surgir en Inglaterra algo en lo que nadie hasta entonces había pensado, una nueva sociabilidad de fuerza insospechada, y siempre renovada, capitalista, que irá muy brutalmente (en términos históricos) cancelando la vieja sociabilidad feudal, en aquello en lo que exactamente lo precise para garantizar su expansión. Y los sucesivos desequilibrios y ajustes de poder, que surgirán a lo largo de los siglos futuros, entre ambas sociabilidades en Inglaterra -capitalista (emergente) y feudal (decadente)- explicaran a largo plazo (para nosotros sociólogos, para ésta nuestra Sociología Histórica) los sucesivos desequilibrios 
y ajustes de poder entre representantes (Comunes) y personados (Lores) en el interior mismo de Rex in Parlamento. ${ }^{16}$

Pues la propia espontaneidad transversal de las personalidades, junto con el principio de la formalidad legal que todos aceptan, garantiza que ese artilugio político no perderá en ningún momento histórico (bueno, casi en ningún momento) su condición de fiel retrato, de perfeccionado trasunto de la sociedad inglesa de su tiempo. ${ }^{17}$

\section{Mercantilismo}

Desde 1337 hasta 1453 Inglaterra se encuentra en guerra intermitente, pero continua, con su riquísima vecina francesa. Durante esos Cien Años ¿es England una sociedad en pie de guerra o simplemente una sociedad que tiene que hacer frente (fiscalmente) a una guerra? Cualquiera que sea la respuesta, el caso es que el esquema se repite en todos los Parlamentos del siglo XIV: las necesidades del Rey reclaman urgentemente (entre otros) los recursos financieros de Los Comunes. Por eso estos maduran rápidamente en materia fiscal, mientras lo hacen mucho más lentamente en su conciencia política (aunque no faltan episodios impresionantes, como el protagonizado por el llamado Good Parliament de 1376, en el cual Los Comunes promueven y logran ni más ni menos que el impeachment del Chancellor, del Treasurer, y de varios otros consejeros directos del Rey).

Aunque subjetivamente vivida al principio como una guerra dinástica, feudal, en su prolongación aportó sin duda grandes beneficios objetivos: pues la herida normanda, feudal, todavía sangrante, fue hábilmente trascendida y sublimada en una identidad común, nueva, inglesa, nacional, capaz de aglutinar, hablando en inglés, a todos los estamentos y clases personados y representados en El Parlamento.

Pero la guerra era cara, carísima ¿y qué recursos podía movilizar nuestra querida y pequeña Inglaterra, para conjurar el peligro sentido de una nueva invasión desde la grande y riquísima Francia?

A principios del siglo XIV en toda Inglaterra tan solo Londres contaba con más de 80.000 habitantes, aunque era ya el puerto más activo de todo el Norte y Occidente de Europa. Además otras ciudades inglesas, en concreto York,

\footnotetext{
16 "The reformers were more like the guardians of some venerable cathedral, restoring it stone by stone as it fell into decay, than architects with a new vision, which they were in has to be realized.", Veitch, 1913, citado por González García (1927: 166).

${ }^{17}$ En una ocasión un jovencísimo Pablo Picasso pintó en París a una millonaria norteamericana, pero ésta, disgustada con el resultado, se quejó de no parecerse al retrato. El pintor se encogió de hombros y le dijo: ‘¡No se preocupe señora, ya se parecerá!'.

La relación entre la sociedad inglesa y el Parlamento inglés puede entenderse también de parecida (aunque no exactamente de la misma) manera: ha sido el Parlamento (y particularmente Los Comunes) los que de hecho han ido formateando a lo largo de los siglos a la sociedad inglesa, hasta hacer de ella lo que es hoy (para bien y para mal). Han logrado hacer cumplir su propia profecía.

Todo esto aún se verá más claro en el caso de los EE. UU.
} 
Winchester, Norwich y Bristol, tenían más de10.000 habitantes, mientras que otras 75 towns y burgos (muchos de ellos puertos de importancia regional) superaban los 2.000 .

En esas ciudades, al lado de los tradicionales oficios artesanos, agrupados por gremios -herreros, taberneros, zapateros, hilanderos, carpinteros, canteros, etc. etc., pero también joyeros, ebanistas, orfebres, peleteros, prestamistas, libreros,... todos ellos contratados sobre todo por obispos, cortesanos, y burgueses -. Al lado de estos gremios, digo, estaban surgiendo nuevos y pujantes sectores económicos con un creciente recurso al trabajo asalariado. Entre ellos, y en primer lugar desde luego, todo lo que tenía que ver con la armazón y reparación de barcos, la contratación de sus tripulaciones, las empresas de importación de vinos, grano, aceite, sal, bienes de lujo, especias, manuscritos, ropas italianas, etc. etc. creadas por los merchants (sobre todo de Londres) que los fletaban. Pero también el transporte terrestre entre esas ciudades, y entre ellas y sus hinterlands aldeanos (transporte de frutas, pan, hortalizas, carne, pescado, etc. etc.) creaba y movilizaba muchísimo empleo. Pero no tanto seguramente como la fabricación de armas y los ejércitos de soldados que las usaban en las constantes guerras contra Francia. Y las obras públicas de todo tipo, civiles y de defensa, religiosas, y también privadas, así como las incipientes empresas de minas, de cerámica, cristal, textiles, sedas, cuero, jabón, libros, algodón, tintes, acero, cobre, aluminio, etc. etc., contrataban casi exclusivamente mano de obra temporal, mucho más versátil y adecuada (que la sujeta a las obligaciones gremiales) para su expansivo, pero incierto crecimiento. ${ }^{18}$

Las cosas en el campo seguían un camino parecido. La debilidad del rey ante los barones se reproducía desde el mismo siglo XII como debilidad de los barones ante sus siervos, que no reconocían en ellos sus 'mandos naturales' (laminados en Hastings). Muchos de ellos consiguieron forzar a sus señores a que admitiesen sustituir las servidumbres agrícolas (ad opus) por rentas monetarias (ad censum), lo que se agudizó decisivamente después de la Black Death (1350), por la escasez de mano de obra, diezmada por la peste. Los Comunes reaccionaron apoyando sucesivos Statutes of Labourers (1351, 1373-5), donde se fijaba el salario máximo para las distintas labores, y la persecución por los tribunales de los que faltaban a Ley, pero inútilmente, pues nunca consiguieron que realmente se aplicaran. Los mismos Lords se saltaban sus propias leyes, ofreciendo escondidamente salarios cada vez más altos, por una mano de obra cada vez más escasa y necesaria:

"The most effective way of retaining labour was to pay higher wages, just as the most effective way of retaining tenants was to lower rents and release servile obligations." Postan (1972: 152).

\footnotetext{
${ }^{18}$ Toda esta diligencia mercantil fue en mucho favorecida por la excepcional centralidad de la política inglesa, pues todas sus ciudades estaban igualmente subordinadas al poder único del rey, y por lo tanto no sufrían mayor regulación ni jerarquía entre ellas que la red que pudiera resultar de su eventual funcionalidad económica.
}

Sobre esto, y para una comparación con las ciudades-estado del siglo XIV del Norte de Italia, puede verse Britnell (1991). 
La conmutación de la sujeción servil a la tierra por la compra de la misma, libre ya de toda servidumbre manorial, se generalizó en muchos condados de Kent y de East Anglia. Otros muchos en cambio, favorecidos por un sistema de herencia partible, decidieron emigrar con unos pocos ahorros a las ciudades, particularmente Londres, en busca de fortuna, queriendo acogerse (en cualquier caso) a sus prestigiosas libertades. El campo se llenó de una población rica, activa e independiente, y cuando se produjo la famosa Peasants' Revolt de 1381 contra la primera Poll Tax (1377), fueron precisamente los condados ingleses más ricos y avanzados ( $\mathrm{y}$ no los mas pobres y serviles) los que protagonizaron los más violentos y airados disturbios.

Pero aunque semejantes o parecidos desarrollos capitalistas se estaban dando simultáneamente en otras partes de Europa, con su misteriosa eficacia, en el caso inglés, a partir del siglo XIV en adelante, y hasta hoy, hay algo distintivo y único, que no es sino que Rex in Parlamento lo está impregnando todo, impregnando con su procedimiento todos los otros procedimientos de la vida civil, también los de la contratación económica.

Nos referimos tanto a los aspectos formales de dicho procedimiento, al hecho de que, en esa Asamblea, se admite, como cosa hecha, que serán simplemente los poderes fehacientemente en ella personados y representados, los que, en su libre juego de fuerzas, decidirán, a lo último, el contenido y la aplicación de la ley, sin que se admita como trascendente per se ningún principio, salvo que como tal se haga en la práctica valer en el curso de la discusión misma, pero no, ya digo (y esto es lo revolucionario en una época católica y feudal) per se. Por ejemplo, puede alguien hacer querer valer en la tramitación de una ley cualquiera, una prerrogativa tradicional del Rey cualquiera, o el sentir (típicamente proto-nacionalista) de la sacralidad de la Isla, pero esos principios valdrán en la Ley justamente lo que resulte de su ponderación por los interlocutores que lo están escuchando. O tal vez nada. ${ }^{19}$

Y en cuanto a los aspectos materiales del procedimiento de Rex in Parlamento, sí parece que este último sentir nacionalista debió en efecto ir adquiriendo en Inglaterra más y más peso a lo largo de esa centuria XIV, y particularmente en el corazón de los Comunes cuando reunidos, pues ellos fueron, al decir de Weber, muy precoces e incluso pioneros en el nacionalismo económico, esto es: en la expresión económica del nacionalismo, que con el tiempo se dará en llamar mercantilismo:

"Y, en términos generales, Inglaterra es el país de origen del mercantilismo. Las primeras trazas de su aplicación se encuentran allí en el año 1381. Al producirse, bajo el débil rey Ricardo II, una escasez de dinero, el Parlamento nombró una comisión investigadora, que es la que primero trabajó con el concepto de balanza comercial, con todas sus características esenciales. Al principio solo produjo leyes ocasionales: prohibición de la importación y favorecimiento de la exportación, pero sin que por ello toda la política inglesa

${ }^{19}$ ¿Es este Rex in Parlamento uno de los orígenes del afamado individualismo inglés? Parece lógico pensarlo, sin embargo, curiosamente, el historiador británico Alan Macfarlane (1978) no se para a considerarlo así ni una sola vez siquiera, en su por lo demás interesantísimo libro. 
adoptara una orientación mercantilista. El cambio decisivo suele situarse en 1440. En aquella ocasión surgieron (por medio de uno de los numerosos Statutes of employment decretados para combatir las deficiencias señaladas) dos puntos de vista que ya se habían elevado antes, pero sólo ocasionalmente, a la categoría de principio, a saber: los comerciantes extranjeros que llevan mercancías a Inglaterra han de invertir todo el dinero que por ellas reciben en mercancías inglesas y: los comerciantes ingleses que van al extranjero han de devolver a Inglaterra, en moneda constante, una parte por lo menos del producto obtenido. A estas dos formulaciones se fue luego adaptando progresivamente el sistema conjunto del mercantilismo, hasta la Ley de Navegación de 1651, con la exclusión de la navegación extranjera." Weber (1964: 1054).

\section{Cisma de Roma}

En el año 1500 cuando el diplomático veneciano Andrea Trevisano visitó Inglaterra, se admiró, entre otras cosas, de que las familias inglesas pusieran a sus hijos no primogénitos, hombres o mujeres, a partir de los 7 ó 9 años, a servir como aprendices en otras casas que la suya, teniendo a partir de entonces que ganarse la vida por si mismos, sin esperanza alguna de heredar nada de sus padres...

"The author perceptively noted that this meritocratic system, so different from a domestic mode of production, where the family form one economic unit, leads to insecurity and the desire for constant accumulation. Yet he also conceded that such a system allows very considerable social mobility, describing at great length how apprentices amass a fortune later in their life... This individualistic, self-help, social system was also shown not merely in national character and economics, but also in religion." Macfarlane (1978: 175).

En 1565 Sir Thomas Smith, embajador de Inglaterra en Francia, escribió un libro sobre 'La manera de gobierno o política en el Reino de Inglaterra', comparando esa manera con aquellas del continente, en donde entre otras cosas dice (traduzco):

"Los labradores abastados no se consideran a sí mismos caballeros, pero honran a todos aquellos que se tienen por tales, y además tienen cierta importancia y son más estimados que los jornaleros y artesanos, y viven por lo común en buenas casas, haciendo negocios, y trabajando para conseguir riquezas; son (en su mayor parte) propietarios que quieren ser caballeros, que cuidan sus ganados, frecuentan los mercados, y poseen sirvientes no perezosos, como hacen los caballeros, sino sirvientes que buscan su propio bienestar y el de sus amos, adquiriendo por esos medios tal riqueza que pueden compran las tierras de los caballeros derrochadores, y después de mandar a sus hijos a las universidades, a estudiar las Leyes del Reino, o dejarles suficientes tierras como para vivir sin trabajar, logran de este modo que sus hijos se conviertan en caballeros." Macfarlane (1978: 176) 
En ambos testimonios de época, recogidos y comentados en el ya citado libro de Macfarlane, vemos la imparable emergencia de la cultura empresarial y el trabajo asalariado entre la ciudadanía de los nacidos ingleses, sobre todo en Londres, los condados de East Anglia y del Sur de la Isla. Pero junto a ella, y también entre ingleses de nacimiento o nación (pues no lo eran menos), la vieja sociabilidad feudal o manorial, del pueblo servil y artesano, resistía hasta cierto punto intocada el paso del tiempo, sobre todo en los condados más rurales del Norte y del Oeste de su querida Isla.

Aunque desde luego, la transición entre las dos Inglaterras era 'completamente fluida' (como apuntaría Max Weber), y aun eventualmente protagonizada al tiempo por la misma persona:

"La perspectiva era como con la tierra libremente detentada, que un hombre podía permitir que la costumbre dictase la situación, podía morir sin hacer una sola venta o enajenación de su tierra, y en este caso su primogénito heredaría. Pero también, muy a menudo, el elegía hacer algo distinto -bien fuera vender una parte, donarla, hacer una disposición para sus hijos e hijas más jóvenes, o actuar de otras maneras que convertían a la costumbre simplemente en una posibilidad no realizada." Macfarlane (1978: 108) [traducción mía]. ${ }^{20}$

Pero naturalmente, esas dos Inglaterras no estaban ponderadas por igual ante el "Rey en Parlamento". Ya en 1430 éste órgano político decidió que tan sólo los hombres que poseían una propiedad de al menos 40 chelines podían votar para elegir a los miembros de Los Comunes. Los cuales, a su vez, para poder ser elegidos, debían poseer unos ingresos anuales superiores a las 600 libras, para representar a los condados, y de 300 libras, para representar a las ciudades.

Por otro lado, los reyes Tudor, todos ellos, pero muy particularmente el primero, Enrique VII (1485-1509), unieron su destino a la creciente importancia de las clases mercantiles, a costa de la nobleza, buscando someter también a las autoridades locales, por medio del nombramiento de sheriffs leales, que, en su nombre, supervisaban las cortes del condado, la recogida de impuestos, la ejecución de las decisiones de los justicias de paz, y, sobre todo, la elección de los candidatos al Parlamento.

De aquella época, por ejemplo, procede el famoso Book of Rates, que establecía valores estándar para los bienes comercializados por los ingleses, priorizando su promoción, y con ella una mayor recolección de tasas para El Reino.

A partir de 1527 Enrique VIII busca tenaz y calculadamente su divorcio de Catalina de Aragón. La reina no es capaz de darle el heredero varón legítimo que Inglaterra necesita, y Roma no quiere anular su matrimonio. El rey, en una visita casual a Wiltshire, conoce a Thomas Cranmer, un oscuro scholar

${ }^{20}$ Interesantísimo distanciamiento instrumental, ambigua actitud, doble movimiento, ante dos sociabilidades contemporáneas; doble movimiento que tal vez (aplicado a nuestro fines) tendría mucho que enseñarnos a nosotros, ciudadanos occidentales del tercer milenio (como veremos al final de todo). 
comprometido con el Protestantismo. Entre él y Thomas Cromwell (al mando del Consejo Real) encontrarán e impulsarán la única solución que ellos vislumbran: la reconversión de la Iglesia Católica en Inglaterra en una Iglesia de Inglaterra, o Anglicana, que autorice el nuevo matrimonio del Rey. Un cisma en toda regla. El Parlamento apoya sucesivamente todos y cada uno de los pasos que va dando el Rey. En primer lugar, un Acta por la cual Enrique es reconocido como Cabeza de la Iglesia en Inglaterra (1531), en 1532 se acepta a Thomas Cranmer como arzobispo de Canterbury, en 1534 un Acta de Sumisión del Clero, y otra sobre nombramientos eclesiásticos, o la famosa Acta de Supremacía (1534), y el Acta de Sucesión (1536), y desde luego aquella que pone en las manos del Rey todas las riquísimas propiedades de los monasterios (1539), más o menos una sexta parte de toda la tierra de Inglaterra.

Suele enfatizarse el apoyo y contento de la gran nobleza con ésta última medida del Monarca en el Parlamento, y también el de Los Comunes, que veían en ella la entrada de las mejores tierras de Inglaterra en un mercado siempre creciente y codicioso. Y es cierto. Pero en realidad, en este cisma de la Iglesia de Inglaterra, había mucho más en juego, para Inglaterra misma y su destino (y para el destino del resto del mundo), como Thomas More y otras cabezas preclaras e independientes supieron desde un principio entrever. Se trataba (para bien y para mal) ni más ni menos que del comienzo del fin de la Inglaterra feudal, del pueblo servil y artesano, y del comienzo del triunfo sobre ella de una Inglaterra capitalista, de la ciudadanía empresarial y asalariada... La única Inglaterra que hoy existe (y casi la única que se recuerda).

Para intentar comprender el alcance de lo que estamos comentando, vamos a aplicar aquí el concepto de Soberanía, tal y como lo elaboró en su día Nicolás Ramiro Rico. ${ }^{21}$

Según nuestra interpretación del texto de Ramiro Rico, la Soberanía, esto es: el logro por parte de un determinado poder de que la gente le obedezca, exige siempre que la gente prefiera ese poder entre otros poderes en concurrencia, que también pretenden lograr su obediencia, alcanzar la Soberanía. Durante la Edad Media había básicamente dos poderes en disputa, el Rey y la Iglesia Católica. Pero la Soberanía en realidad la tenía siempre Roma, de modo que cuando un Rey (por lo que fuera) desobedecía a la Iglesia, ésta pedía a los súbditos del Rey que se rebelasen por activa y por pasiva contra Él, y llegado el caso, pedía a los reyes vecinos que lo atacasen.

Que la Iglesia era la verdadera soberana se ponía de manifiesto en la necesidad que tenían los Reyes de ser ungidos por la Iglesia, en una ceremonia cargada de toda solemnidad y simbolismo, sólo a través de la cual efectivamente el Rey accedía al trono, reinando entonces "Por la Gracia de Dios". Pero la Iglesia también necesitaba a los reyes, pues al delegar en ellos el ejercicio cotidiano del poder terrenal directo, preservaba en la narración (en

\footnotetext{
${ }^{21}$ Ramiro Rico (1952). Este artículo puede también encontrarse en Ramiro Rico (1980: 119135).
} 
una narración convencionalmente por todos mantenida, y que en esa misma medida, no era tenida por ficticia) su propia filiación divina.

Para nosotros los modernos (y particularmente para nosotros los sociólogos) no resulta fácil comprender esta creencia, esta ficción política medieval. Sí, comprendemos que fue la Iglesia de Roma la que a lo largo de centenas y hasta miles de años -por poner una fecha, a partir de la conversión del emperador Constantino en el año 313- fue formateando a las sociedades de campesinos y artesanos de Europa Occidental, creando el pueblo de la Cristiandad, y formateando muy especialmente su sociabilidad familiar como patriarcal, por la administración de los tres fundamentales ritos de pasaje de los humanos: el nacimiento, el matrimonio, la muerte. Pero lo difícil de comprender para nosotros los modernos, es que los medievales de toda condición sentían que dichos ritos o ceremonias religiosas eran algo más que meros actos administrativos, eran verdaderos sacramentos, donde era posible atraer a la divinidad, ya que el sacerdote, por ser del linaje de Pedro (el primer obispo de Roma), podía personar en ellos al mismísimo Jesús de Nazareth, El Hijo de Dios -que lo había personalmente nombrado (a Pedro, digo).

De modo que cuando Henry VIII y algunos de sus sucesores fueron profundizando el cisma de la Iglesia en Inglaterra, Roma actuó según costumbre: los excomulgó, y pidió a sus súbditos ingleses, sacerdotes y laicos, que no obedecieran a su Rey. Esto explica porque en las Oath of Allegiance, sistemáticamente exigidas por los reyes ingleses a sus súbditos en el momento de acceder al trono, podía leerse:

"3. And I do further swear, That I do from my heart abhor, detest and abjure, as impious and heretical, this damnable doctrine and position, That princes which be excommunicated or deprived by the Pope, may be deposed or murdered by the subjects, or any other whatsoever."

Por ejemplo en esta Oath del año 1606, del rey James I Stuart, en su cláusula tercera, recogida en Dures (1983: 99).

La Iglesia Católica, con toda coherencia, pidió también a Carlos $\mathrm{V}$, el Emperador de Alemania (a la sazón también Rey de España, y sobrino carnal de la reina inglesa, Catalina) que actuara contra Inglaterra, y la devolviera a la obediencia católica. Después de décadas de insistencia, finalmente Felipe II (que había vivido dos años en Londres) envío su Felicissima Armada, en 1588, que naufragó estrepitosamente ante las costas inglesas (lo que fue interpretado como "Una Señal" por los protestantes ingleses... y europeos).

Pero ahora sí la Ciencia Política nos permite comprender que los españoles podían en aquella jornada haber conseguido tal vez el dominio (militar) de la Isla, pero nunca (propiamente) su Soberanía. Pues la principal cuestión sigue en pie: ¿Por qué los católicos ingleses, seglares o laicos, no desobedecieron a su Rey Enrique cuando éste fue excomulgado? ${ }^{22}$

\footnotetext{
${ }^{22}$ Aunque significativa, poco relieve histórico tiene la Pilgrimage of Grace, un levantamiento campesino y nobiliar de algunos condados de York y Lincoln en el año 1536, pidiendo la vuelta de Inglaterra al Catolicismo Romano. 220 fueron ajusticiados.
} 
Pues por qué habría de ser sino, que desde hacía ya 250 años los ingleses contaban con un sistema de gobierno desconocido en otros lares (al menos en cuanto que procedimiento), y al que venimos nombrando Rex in Parlamento, que venía también formateando por su cuenta, y con gran rigor y eficacia, a una parte cada vez más significativa de la sociedad en Inglaterra, particularmente en Londres y su área de influencia (pero no sólo), favoreciendo en toda la Merry England la expansión del mercantilismo, el recurso al empleo asalariado, protegiendo a las empresas que lo crean y profesionalizan, haciendo germinar y proliferar por toda la Isla a unos propietarios alegres, diligentes e independientes, cada vez más seguros de sus propios logros y orgullosos de los sus (según ellos) ancient rights, individuos incapaces ya de obedecer a cualquier otro poder que no sea el de una Asamblea, una asamblea donde de algún modo -más o menos perfeccionado, que esa es otra cuestiónse sientan representados. Esto es: formateando en ciudadanos a los nacidos ingleses de cualquier condición, algo que no estaba pasando por entonces (con esa extensión y profundidad) en ninguna otra parte del Continente ni del mundo: la germinación y proliferación por doquier entre los ingleses de individuos sujetados a dicha sociabilidad ciudadana -aun haciéndolo con distintos protagonismos, fortunas y clases.

Precisamente porque esa sociabilidad capitalista tenía en Inglaterra (y solo en Inglaterra) acceso a la representación en el procedimiento de gobierno, consensuado por el Monarca en el Parlamento, todos los ingleses sin excepción, no ya los ciudadanos cada vez más numerosos efectivamente envueltos en prácticas proto-capitalistas, sino también gentes mucho más humildes, del pueblo, siervos y artesanos todavía feudales, y en general cualesquiera otras categorías sociológicas que pudiera haber in between, todos los ingleses digo, a mediados del siglo XVI, aceptaban ya positivamente como único depositario posible de la Soberanía Inglesa tan solo a dicho, y únicamente a dicho Rex in Parlamento. Una Soberanía que se sabía fraccionada en su interior, pero que ya por entonces (en cuanto que procedimiento), se admitía inapelable.

Pero para la inmensa mayoría de los católicos ingleses (que eran en tiempos de Enrique prácticamente todos los ingleses), la decisión cismática de sus Reyes en Parlamento planteó sobre todo un problema de conciencia (un problema grave de conciencia), pero mucho más raramente una llamada a la desobediencia política. Veamos sino por ejemplo la inteligente defensa de una tal Cecily Stonor (sin duda perteneciente a la gentry, sino a la nobleza), ante quienes en 1581 la juzgaban en Oxford por negarse a recusar su catolicismo:

"I was born in such a time when holy mass was in great reverence, and brought up in the same faith. In King Edward's time this reverence was neglected and reproved by such as governed. In Queen Mary's time, it was restored with much applause; and now in this time it pleaseth the state to question them, as now they would do me, who continue in this Catholic profession. The state would have these several changes, which I have seen with mine eyes, good and laudable. Whether it can be so, I refer it to your Lordships' consideration. I hold me still to that wherein I was born and bred; and find nothing taught in it but great virtue and sanctification; and so by the grace of God I will live and die in it."

Testimonio recogido en el citado libro de Dures (1983: 94). 
Tanto es así que cuando la Reina Mary, la hija de Catalina de Aragón, en 1555, quiere ajusticiar a Thomas Cranmer, el primer arzobispo protestante de la Nueva Iglesia, tiene que convocar al Parlamento para que éste rechace formalmente los actos de Enrique VIII y Eduardo VI, y reintroduzca las leyes que permiten al poder secular quemar herejes. $Y$ tanto es así que el propio Cranmer acepta dignamente morir quemado por hereje, y así lo hace constar por escrito, toda vez que la Reina, reunida con el Parlamento, ha restaurado en Inglaterra con toda legalidad la fe Católica. ${ }^{23}$

Pero es que si Ramiro Rico acierta con su concepto genérico de Soberanía, comprendiéndola como resultado de la preferencia mostrada por gentes cualesquiera a obedecer a uno de entre varios poderes concurrentes, entonces en esta genial inventio inglesa de recurrir a la representación de esas mismas gentes para su Gobierno, hay algo que trasciende en mucho a su función en la particular historia de los ingleses, sino que se trata de uno de esos raros productos culturales que rebasan su propio nacimiento en una sociedad determinada, para regalarse al uso y servicio de todas las demás culturas planetarias, pues en esto del Gobierno por Asambleas Representativas hay algo genuinamente humano, antropológico, universal.

Que nació por la debilidad del rey normando antes sus barones, sí. Que se consolidó históricamente (tal como hoy lo conocemos) gracias a la emergencia del capitalismo en Inglaterra, también. Pero si la soberanía, como cree Rico, y nosotros, es la preferencia de las gentes por un Poder entre varios concurrentes, entonces hay algo auténtico, algo verdadero, algo indiscutible, en esto de que las gentes elijan representadores para someterse a Ellos. ${ }^{24}$

Pero volviendo a nuestra atribulada Isla, la separación de la Iglesia Anglicana dinamitaba de facto (más allá de toda la verborrea que hubo de acompañarla) todo el entramado institucional medieval, sobre todo en su estratégica narración legitimadora, pues la Nueva Iglesia, que no podía filiarse a Pedro, no podía decirse divina, y el Rey, al convertirse en su Cabeza, no podía ser ungido 'por la gracia de Dios', ya que era él mismo quien se ungía. Si Enrique y Cranmer creían estar construyendo, respectivamente, un sólido futuro para su Casa Real e Iglesia, bien pronto (bien pronto en términos históricos) habría de verse que otros poderes en el interior de Rex in Parlamento estaban llamados a llevarse el fervor ciudadano, y con él el gato de la verdadera Soberanía al agua. Esos otros poderes necesitaron desde luego desarrollar su propia sacralidad, sus propias religiones, pues

"es un error histórico de muchos creer que el proceso secularizador ha consistido en Occidente en una profanación de lo sagrado, sin mirar al proceso paralelo que diviniza lo mundano." Rico (1980: 120).

Los nacionalismos estarán llamados a ser con el tiempo una de esas nuevas y triunfantes religiones.

${ }^{23}$ BRITANNICA ONLINE ENCICLOPEDIA (2010): voz 'Thomas Cranmer'

${ }^{24}$ Sobre el antiquísimo origen de los conceptos de 'persona' y 'representación', véase la introducción de Carlos Moya a la edición de Hobbes (1979), particularmente pp 93-104. 


\section{El Rey es decapitado}

Entre 1500 y 1650 Londres multiplica por 8 su población. A su función panóptica con los puertos atlánticos de Alemania, Holanda, Norte de la Península Ibérica y Países Bálticos (fagocitación de la antigua Hansa), se suma desde 1607 el vibrante tráfico pivotal de materias primas y manufacturados entre la gran ciudad y puerto y sus colonias de la costa atlántica del Norte Americano. Cuanto más rápido es un cambio social, menos capacidad de ser colectivamente pensado, y nada más difícil que pensar el capitalismo para las poblaciones que se apropian de su expansión, precisamente por su índole abstracta:

"En la perspectiva histórica, la institución del trabajo asalariado es una recién llegada. La idea misma del trabajo asalariado requiere dos difíciles pasos conceptuales. Primero, exige la abstracción del trabajo de un hombre, aparte de su persona y del producto de su labor. Cuando alguien compra un objeto de un artesano independiente, sea libre, sea esclavo con peculium, no le ha comprado su trabajo, sino el objeto, fabricado por él en su propio tiempo y en sus propias condiciones de trabajo. Pero cuando alguien contrata mano de obra, compra una abstracción, la fuerza de trabajo, que el comprador emplea en un tiempo y en unas condiciones que determina él, el comprador, no el 'propietario' de la fuerza de trabajo (y por la cual normalmente paga después de haberla consumido). Segundo, el sistema laboral asalariado requiere el establecimiento de un método para medir el trabajo que se ha comprado, con propósitos de pago, por lo general introduciendo una segunda abstracción; a saber, el tiempo de trabajo.

No debemos menospreciar la magnitud -social más que intelectual- de estos dos pasos conceptuales; aun para los juristas romanos resultaron difíciles..." Finley (1975: 86).

Pero el capitalismo (incluso este capitalismo sin chimeneas, anterior a las máquinas), el consumo de trabajo asalariado, ese cultivo de la fuerza de trabajo ajena, ese consumo de la fuerza de trabajo ajena (que genera más valor de lo que costó, y que gracias a la constante invención de máquinas, cada vez engendra más valor, cada día mucho más valor de lo que cada día cuesta)... Esa labour-culture ${ }^{25}$, digo, es para las sociedades en las que progresa lo mismo que el fuego para una cazuela de agua: termina por cambiarla de estado, por hacerla hervir, de líquido a gas. Y cuanto más capitalismo, ya se sabe, más revolución en las ideas, en las ideas de los que lo protagonizamos, esa incesante búsqueda de ideales sociales e individuales que nos caracteriza a todos nosotros los modernos (más allá de nuestras patéticas realizaciones de tales ideales). ${ }^{26}$

\footnotetext{
${ }^{25}$ Compárese con agri-cultura, o acui-cultura.

${ }^{26}$ Cfr. Oakeshott (1948-9).
} 
Por toda Inglaterra -como también por toda la Europa entusiásticamente capitalizada- se extiende entre las clases proto-burguesas la costumbre de leer en privado la Biblia, buscando con ello sobre todo sentirse importantes, por distinguirse a la vez de los campesinos (a los que tildan de primitivos, salvajes, y supersticiosos, pues viven con animales, maltratando animales, y como animales); y distinguirse también de los nobles (salvo emparentamiento de las hijas con ellos, claro), que siempre despreciaron leer.

Y entre los más humildes, y recién incorporados al conocimiento del truco de la acumulación de capital -pero no menos ansiosos de negarse a sí mismos (subjetivamente) su propia condición de campesinos que sin embargo (objetivamente) todavía casi seguían siendo- ese protestantismo, digo, adquiere profundos caracteres místicos, como aquel que se hizo tan famoso de la ruralidad de Grindleton, cerca de la ciudad de York, donde en 1587 propietarios y aparceros habían llegado a un acuerdo para enclaustrar y dividir las tierras del común, y cuyo pastor Roger Brearley es llevado 30 años más tarde ante los tribunales acusado de profesar (entre otras cosas) que:

"(1) a motion rising from the spirit is more to be rested in than the Word itself; (2) it is a sin to believe the Word... without a motion of the spirit; (3) the child of God in the power of grace does perform every duty so well, that to ask pardon for failing in matter or manner is a sin; (7) the Christian assured can never commit a gross sin; (14) a soul sanctified must so aim at God's glory, as he must never think of salvation; (33) a man having the spirit may read, pray or preach without any other calling whatsoever; (38) neither the preacher nor they pray for the King... They know not whether he be elected or not; (46) they cannot have more joy in heaven that they have in this life by the spirit." Hill (1972: 83).

De modo que por un lado estaban la fe y la disciplina que por aquel entonces los burgueses ponían en sus particulares negocios y en su vida privada, donde su comportamiento ejemplar los hacia parecer verdaderos santos a los ojos de los mas desfavorecidos, logrando poner en evidencia sin querer queriendo la corrupción de los caballeros en la Corte.

Y por el otro, estaban las confesiones de Ranters, Levellers, True Levellers, Seekers, Diggers, Quakers y demás humildes, que quisieron en ocasiones hacer efectiva su fe utópica y reformada, más peligrosa cuanto sus excesos prendían entre los soldados de los ejércitos.

De ahí esas prácticas violentas contra los papistas, no solo institucionales, por las autoridades locales, y de la Iglesia y del Estado, sino sobre todo por esos true believers, más o menos calvinistas, más o menos republicanos (a pesar de ser ingleses), que veían en el catolicismo (y en eso no se engañaban) el mejor fundamento de los prejuicios aristocráticos que tanto odiaban.

Así las cosas, el 23 de Junio de 1625 se abrió el primer parlamento convocado por Carlos I Estuardo, e inmediatamente se levantó Sir Robert Cotton y habló así: 
"No pedimos al rey que despida sus malos consejeros, como se hizo en tiempos de Enrique IV y Enrique VI; no queremos intervenir en su elección, como en los reinados de Eduardo II, Ricardo II y los dos Enriques ya nombrados; no deseamos que lo elegidos deban prestar juramento ante el Parlamento, como acaeció bajo los reinados de Eduardo I y II y de Ricardo II; ni que se les señale la conducta que deben seguir, como se practicó bajo Enrique III y Enrique IV; ni que su majestad prometa, como Enrique III, que nada practicará sin el consentimiento del Gran Consejo del país: sólo expresamos como fieles súbditos, nuestros modestos deseos." Guizot (1985: 33).

El Rey disolvió las Cámaras.

¿Pero que pasó aquí? ¿Cómo es que aquellos dóciles Parlamentos de los Tudor y primeros Stuart se habían transformado en este levantisco del rey Carlos? ¿O es que aquellos Parlamentos tampoco eran tan dóciles como parecían? ¿O tan sólo dejaban hacer al Rey lo que a ellos les convenía?

Para contestar a estas y otras preguntas, no necesitamos más que observar a quienes se sentaban en las bancadas de Los Comunes: por un lado estaban una mayoría de gentrys, básicamente leales a la tradición inglesa (Rex in Parlamento), pero ahora muy penetrados por las ambiciones directamente políticas de las burguesías londinenses, cuya lógica universal, penetrada del espíritu abstracto del mercado, reclamaba intervenir activamente en cada vez aspectos más sustanciales del gobierno real, y aun de la prerrogativa real: libertades de arresto, derechos de propiedad, tolerancia religiosa, estancos o monopolios, fundación de colonias, nombramientos de consejeros reales, definición de impuestos, recluta y uso de la marina de guerra, etc. etc. La maduración de la burguesía como clase desbordaba una y otra vez y por todos lados, a veces conscientemente, otras apenas sin saberlo, sus vetustos límites estamentales.

Pero por otro lado habían llegado desde los condados elegidos bastantes roundheads o puritanos, más o menos sentidos y reformados, cuando no radicales -entre los que se dio a conocer, en representación de Cambridge, un joven Oliver Cromwell (sobrino-bisnieto de aquel Canciller de Enrique VIII)-, que aunque solo fueran una minoría, era muy apasionada y activa, manejando un lenguaje airado y ruidoso contra la monarquía como institución, un lenguaje audaz y hasta entonces en la Cámara desconocido.

Hasta 1640 El Rey no volverá a convocar un Parlamento, y lo hará por cierto bien a regañadientes, forzado tan sólo por la falta de dinero, el dinero que necesita para hacer frente a una invasión armada desde Escocia. Ese Parlamento, llamado el Largo, pues no se disolverá hasta 1653, bastante más dominado por sentimientos y políticas puritanas, sobre todo (pero no sólo) entre los representadores electos de Los Comunes, se irá transformando muy rápidamente (por sucesivas depuraciones de caballeros) en un Body o Cuerpo revolucionario, dispuesto a enfrentarse al Rey.

Y es que en esos 15 años, indignados con Carlos por la disolución de las Cámaras, muchos ingleses comunes, y algunos de sus representadores en Los Comunes, fueron buscando y trabajando una nueva narrativa, reformadora 
como mínimo de la débil versión oficial Anglicana, incluso inspirándose directamente en Calvino, o en cualesquiera nuevas doctrinas, capaces de servir (siquiera fuera instrumentalmente) para justificar el asalto al poder del Rey, cuando Éste (por lo que fuera) no tuviera más remedio que convocarlos de nuevo en Parlamento.

No se crea sin embargo que el Rey carecía de apoyos, ¡ni mucho menos!, pues siempre contó con leales seguidores de las veneradas costumbres y tradiciones políticas inglesas, como demuestra la votación que tuvo lugar el 1 de Diciembre de 1641 en Los Comunes, para impulsar la Ilamada Grand Remonstrance, que fue aprobada tan solo por 159 votos a favor y 148 votos en contra, a partir de la cual el Rey precisaría la aprobación por el Parlamento de sus consejeros. Tenemos el testimonio de las palabras de sir Edward Dering cuando precisamente se opuso:

"Cuando oí hablar por primera vez de un memorial de reivindicaciones [...] pensé que se denunciaban ante el Rey los consejos perversos de los consejeros perniciosos [...] No soñé que íbamos a reclamar hacia abajo, a contar historias al pueblo y a hablar del rey como de una tercera persona."27

Y es que en efecto, todo el mundo en Los Comunes estaba todo el día hablando del pueblo, bien unos porque el hábito antiquísimo de elaborar leyes abstractas aplicadas al whole realm era ahora modernamente reinterpretado como si los diputados lo fueran ya no de sus particulares pueblos o localidades, sino del conjunto todos de los nacidos ingleses, de los ingleses todos de nacimiento o nación, convertidos por arte de birlibirloque de la noche a la mañana en representantes de la (whole) nación -lo que nunca habían sido (pues no decían eso sus mismas acreditaciones); bien otros, porque preferían apoyarse en ciertos escritos de Calvino, en los que se responsabilizaba a 'subordinate Judges', y aun a 'private men', del deber de vigilar la virtud del gobierno. Y en hablando de "El Pueblo", desde la Primera Persona del Plural, Io inventaban, inventaban una humanidad cargada de derechos -que no eran sino las libertades emprácticas ciudadanas-, una humanidad capaz de oponerse, capaz de equipararse (al menos), a la divinidad del Rey.

Pero bueno, lo estratégico, lo decisivo y clave, era desde luego declarar la guerra al Rey, o conseguir que el Rey la declarase, para lo cual las ofensas del Parlamento se suceden: detención y ajusticiamiento de sus amigos y favoritos: Laud y Strafford; imposición de la convocatoria obligada cada tres años del Parlamento; declaración como ilegales de determinados impuestos reales; petición de que el Rey renunciara (así, sin más) al mando del Ejército; etc. etc. Humillado por el Parlamento, el Rey abandona Londres. Poco después, en Enero de 1642, llegan a York las propuestas de composición de Las Cámaras, que quitaron toda esperanza a los más moderados. Las Cámaras pedían la completa destrucción de la prerrogativa real y la concesión de un poder

${ }^{27}$ Citado en Morgan (2006: 38) [cursivas del texto].

Sobre el papel que juega la posición (política) relativa de las personas en la construcción y uso de los pronombres personales (y entre ellos de los de Tercera Persona) véase García Calvo (1979: 349 y ss.). 
omnímodo. Creación de nuevos pares, nombramiento y revocación de los grandes funcionarios de todo género, educación y matrimonio de los hijos del rey, negocios militares, civiles y religiosos; todo, por decirlo de una vez, debía en adelante estar sometido al formal consentimiento del Parlamento...

"Al leer aquellas proposiciones se indignó altamente el rey. 'Si concediese lo que me pedís -contestó con el rostro encendido de cólera-, aún podrían no presentarse delante de mí sino con la cabeza descubierta; aún podrían besarme la mano y darme el nombre de majestad; aun podrían formularse vuestros mandatos con estas palabras: la voluntad del rey significada por las dos Cámaras; aun podría hacerme preceder de la maza y la espada, y divertirme con mirar un cetro y una corona, ramos estériles que no darían flor porque el tronco estaría seco...; pero en cuanto al poder real y verdadero, yo no sería más que una imagen, un signo, un vano fantasma de rey', dijo, y rompió la negociación." Guizot (1985: 133).

Ambas partes se preparan para la guerra. Aquí aparece el genio militar de Oliverio Cromwell (muy superior por cierto a su condición de doctrinario), inventando la New Army, la guerra moderna:

"Recorrió, en efecto, los condados del este reclutando jóvenes, la mayor parte conocidos suyos, propietarios o hijos de tales, que no necesitaban sueldo ni deseaban la ociosidad; todos entusiastas fanáticos, empeñados por conciencia en la guerra, y que servían a Cromwell por confianza. 'No os quiero engañar les dijo- ni daros a entender que vais a combatir por el rey y el Parlamento, como lo cacarea el despacho que se me ha conferido; si el rey se encontrase delante de mi, le dispararía como a cualquier otro; si vuestra conciencia no os permite hacer otro tanto, retiraos de mi servicio.'. La mayor parte aceptaban sin vacilar, quedando desde aquel punto sometidos a la más exacta disciplina, y teniendo que cuidar bien sus caballos, limpiar esmeradamente sus armas y dormir muchas veces al sereno. Su jefe quería que de los ejercicios militares pasasen a los piadosos, para que la exaltación del fanatismo se hermanase en su mente con la severidad del servicio militar. Al abrirse la campaña marchaban bajo las órdenes de Cromwell 14 escuadrones de tales voluntarios, que formaban en masa un cuerpo de cerca de mil hombres." Guizot (1985: 150).

De todas maneras, si bien en los condados del Este, del centro y del Sudeste predominaban los parlamentarios, en cambio en los del Norte, del Oeste y del Sudoeste, la ventaja era del Rey.

Las razones son, para nosotros sociólogos, obvias: la sociabilidad capitalista era mucho más densa y estaba mucho más extendida en Londres y en torno a la ciudad de Londres, cuyas clases medias, que formaban la ciudadanía alfabetizada, se sentían tendencialmente más cerca de la parte representadora del Parlamento, de la Cámara de los Comunes, y aún de los puritanos de toda condición. Mientras que por el contrario, lejos de su influencia, en los condados más alejados de Londres, la inmensa mayoría de los nobles y de los campesinos (que seguían siendo la mayoría de la nación) seguían sometidos a la sociabilidad feudal, practicando la religión anglicana (cuando no la católica a escondidas), odiando a los puritanos, a los que encontraban como mínimo 
conflictivos y pesados (libido dominandi), y prefiriendo en general a las partes más personadas del Parlamento, a los Bishops, Lords y desde luego al Rey:

"A pesar de la decadencia del régimen feudal, todavía animaban a muchos gentilhombres los sentimientos que habían heredado de sus padres. Ociosos en sus castillos, poco acostumbrados a reflexionar y a discutir, despreciaban a esos ciudadanos parlanchines, cuya rígida creencia proscribía el vino, las diversiones y los placeres de la antigua Inglaterra, y que pretendían dominar al rey, a quien no habían tenido siquiera sus antecesores el honor de servir. Envanecidos con los recuerdos de su propia independencia, se les daba a esos nobles muy poco de las nuevas exigencias de la libertad pública. Como el pueblo, también habían murmurado contra la Corte y la tiranía, pero después de las concesiones del príncipe se indignaba su imprevisión y su lealtad de la obstinación de los innovadores." Guizot (1985: 111). ${ }^{28}$

Y es que "El Pueblo", ese NOSOTROS inclusivo con el que se llenaban la boca algunos puritanos radicales en los Comunes -una Cámara cada día más empequeñecida y desierta, por continuas deserciones hacía el campo real, acusaciones de traición, muertes violentas, depuraciones religiosas y políticas de toda índole, etc. etc. -; el pueblo, digo, era más bien la ciudadanía -a la que ellos mismos pertenecían y que los había elegido: pues solo una alta franquicia económica permitía participar en el sufragio-, y mucho menos el campesinado -que era todavía sin embargo en la Inglaterra de 1640 mucho más que mayoritario (El Parlamento se hizo Largo precisamente porque durante 13 largos años nadie quiso tentar la suerte de convocar otro, que podría haber salido fácilmente realista).

Esta contradicción, entre sociabilidades capitalistas y sociabilidades feudales, que una y otra vez venimos resaltando en el interior de las sociedades inglesas, esa contradicción, si se quiere, entre individuos de la ciudadanía asalariada y alfabetizada por un lado, y núcleos familiares del pueblo servil o campesino, por el otro, fue magistralmente expresada, entrando (por un momento) ya en el locus de la Sociología, esto es: en el terreno de los tipos ideales -y dejando por ello legítimamente atrás las advertencias y cautelas de Weber sobre la condición siempre gradual y fluida que presentan cualesquiera fenómenos sociales en cualesquiera sociedades históricas y empíricas -; esa contradicción, decía, fue expresada magistralmente (eso sí, a la manera francesa), por su principal estudioso, el sociólogo alemán Ferdinand Tönnies, como un contraste -si se admite- entre categorías analíticas:

"La Gemeinschaft (comunidad) es antigua; la Gesellschaft (asociación) es reciente, en tanto que denominación y fenómeno social. Esto ha sido reconocido por un autor que, por cierto, ha enseñado la ciencia política en todos sus aspectos sin penetrar en sus fundamentos. 'El concepto de Gesellschaft (sociedad) en un sentido político y social -dice Bluntschli (Staatswörterbuch IV)- halla su fundamento natural en las costumbres y las ideas del tercer estado. No se trata realmente del concepto de pueblo (Volks-

\footnotetext{
${ }^{28}$ Y tal vez un tal Thomas Nicholson, del condado de York, habló por varios cuando, en 1615, arrojando una bola de nieve a la gente que venía de escuchar un sermón, dijo: 'it was never good world since there were so many sermons.' Citado en Dures (1983).
} 
Begriff) sino del concepto de tercer estado... Su Gesellschaft se ha convertido en origen y expresión de opiniones y tendencias comunes... Doquiera que la cultura urbana florezca y alumbre, aparecerá la Gesellschaft como órgano indispensable. En el campo apenas se sabe nada de esto'." Tönnies (1979: 29) [cursivas nuestras]

Pero en fin, Cromwell ganó la guerra, y capturó al Rey, y lo hizo juzgar por lo que quedaba del Parlamento (después de mandar a su yerno Ireton a purgarlo nuevamente), y lo condenó a muerte, y lo descabezó en Londres, el 30 de Enero de 1649 ¡Exactamente 144 años (y un día) antes que los franceses!

Pero el Cromwell que dio todos estos calculados pasos (verdaderamente históricos), no era ya el fanático puritano de su juventud, ni siquiera tan solo el brillantísimo líder militar que condujo y ganó la guerra, sino sobre todo y ante todo un hombre de estado, un verdadero conocedor de los vicios y virtudes de su amada Inglaterra. $\mathrm{Y}$ al poco de caer la cabeza del Rey Carlos, el mismo Cromwell en persona junto con su maestro Fairfax, se encargan de cortar por lo sano todo dominio de la sectas radicales en el Ejército, derrotando a los Levellers, True Levellers, Seekers, Ranters, Quakers, y demás compañeros de viaje, que cuestionaban el dominio político e ideológico de la Revolución por las clases con propiedades. Ocurre tan pronto como en Mayo de 1649, en Burford. ${ }^{29}$

Ya en 1651, y bajo la garantía personal de Oliver Cromwell, Thomas Hobbes vuelve de su exilio en el Continente, a su querida y estudiada Inglaterra, y se decide a publicar en Londres su Leviatán, donde puede leerse:

"Viendo entonces que todas las leyes escritas y no escritas extraen su fuerza de la voluntad de la república, esto es, de la voluntad de su representante (que en una monarquía es el monarca, y en otras repúblicas es la asamblea soberana), un hombre puede preguntarse de dónde proceden opiniones tales como las que se encuentran en los libros de juristas eminentes para diversas repúblicas, que hacen depender directa o inmediatamente al poder legislativo de hombres privados (private men) o jueces subordinados (subordinates Judges). Como por ejemplo, que la ley común sólo es controlada por el Parlamento; lo cúal sólo es verdad cuando un Parlamento tiene el poder soberano y no puede ser reunido ni disuelto sino por su propia voluntad. Pues si existiese en alguna otra persona el derecho a disolverlo, tendría también un derecho a controlarlo y, en consecuencia, a controlar su control. Y si no hay tal derecho, quien controla las leyes no es el Parlamentum, sino Rex in Parlamento. $Y$ allí donde un Parlamento es soberano, aunque nunca haya reunido tanto ni tan sabios hombres provenientes de los países sometidos por cualquier causa, nadie creerá que tal asamblea ha adquirido por tal causa un poder legislativo. Los dos brazos de una república son fuerza y justicia; la primera reside en el rey, la otra está depositada en manos del Parlamento.

${ }^{29}$ Por eso para elegir los Comunes antes de 1832 había 366,000 personas con voto en Inglaterra y País de Gales (uno de cada 8 hombres adultos) frente a 4500 votantes en Escocia (uno de cada 125 hombres adultos), debido a la alta franquicia económica exigida legalmente para participar en el sufragio. Cfr. Robbins (1989). 
Como si una república pudiera subsistir allí donde la fuerza se concentra en una mano no mandada y gobernada por la autoridad de la justicia." Hobbes (1979: 350-1) [paréntesis añadidos nuestros; cursivas del texto] ${ }^{30}$

\section{A new England}

Otros en cambio, entre los puritanos de la vieja Inglaterra, no tuvieron la paciencia de esperar a ver cual iba a ser el desenlace histórico de su pleito con la Iglesia Anglicana y el gobierno del Rey. Procedentes de la pequeña aldea de Scrooby, cerca de la ciudad de York, ya en 1607 se habían exiliado en DelftHaven (Holanda), para poder vivir conforme a las ideas de su religión. Dedicados a la industria textil, se defendieron bien económicamente, y no eran importunados en su culto, pero el problema era que sus hijos e hijas, al casarse con holandeses, "perdían la pureza de sus costumbres".

Comprendieron entonces que lo que les pasaba, sencillamente, es que no podían sufrir una sociedad que, fuese cual fuese el resultado de las guerras religiosas (políticas), iba a continuar siendo en cualquier caso a sus ojos intrínsecamente corrompida, ya que mayoritariamente campesina.

Decidieron entonces emigrar a América, y crear allí una sociedad completamente nueva, de principio a fin, que hiciese tabla rasa de todas las servidumbres feudales hasta ahora soportadas, una ciudad de santos, A City on a Hill.

Alquilaron un barco, el Mayflower, y en número de 87 peregrinos (más 14 sirvientes) arribaron a la Bahía de Boston en Diciembre de 1620:

“He creído siempre que era un deber sagrado para nosotros, cuyos padres recibieron prendas tan numerosas y memorables de la bondad divina en el establecimiento de esta colonia, perpetuar por escrito su recuerdo. Lo que hemos visto y lo que nuestros padres nos han contado debemos darlo a conocer a nuestros hijos a fin de que las generaciones venideras aprendan a alabar al Señor (Salmo LXXVIII, 3, 4); a fin que el linaje de Abraham, su siervo, y los hijos de Jacob, su elegido, guarden siempre la memoria de las obras milagrosas de Dios (Salmo CV, 5, 6). [...] Es preciso que sepan como el Señor llevó su viña al desierto, como la plantó y alejó de ella a los paganos, como le preparó un lugar enterrando profundamente sus raíces y la dejó después extenderse y cubrir la tierra (Salmo LXXX, 15, 13 [Salmo LXXX, 8, 9]); y no solamente eso, sino también como guió su pueblo hacia su santo tabernáculo y lo estableció sobre la montaña de su heredad (Éxodo, XV, 13). Estos hechos deben ser conocidos con el fin de que [...] a Dios se le otorgue el honor que le

\footnotetext{
${ }^{30}$ En Hobbes (1985), la edición del clásico que Penguin encarga a C. B. Macpherson, éste escribe también una introducción (pp. 9-63) donde argumenta una y otra vez que Hobbes parte en su texto, da siempre por supuesta, y tiene por moralmente aceptable, la sociabilidad capitalista:
}

\footnotetext{
"Hobbes not only accepted market determination of value as a fact, he accepted it as right, in the sense that he could no see other moral basis for establishing the value of anything." Hobbes (1985: 50).
} 
es debido y que algunos rayos de su gloria puedan caer sobre los nombres venerables de los santos que fueron sus instrumentos'."

El autor, Nathaniel Morton, historiador de los primeros años de Nueva Inglaterra, continúa y describe de este modo la partida de los primeros emigrantes:

"'Es así, dice, como dejaron esta ciudad (Delft-Haven) [...] que había sido para ellos un lugar de reposo. No obstante, estaban tranquilos. Sabían que aquí abajo eran peregrinos y extranjeros. No se apegaban a lo terrenal, sino que alzaban los ojos al cielo, su amada patria, donde Dios tenía preparada para ellos su ciudad santa [Hebreos, XI, 16] [...] Llegaron por fin al puerto donde les esperaba el barco...'."

Tocqueville, que visitó los Estados Unidos entre 1835 y 1840, nos dice: "Es imposible leer este comienzo sin sentirse invadido, a nuestro pesar, de una impresión religiosa y solemne. Parece como si en él se respirase un aire de antigüedad y una especie de perfume bíblico.

La convicción que anima al escritor realza su lenguaje. A nuestros ojos, como a los suyos, no es ya una pequeña tropa de aventureros en busca de fortuna allende los mares, es la simiente de un gran pueblo que Dios va a sembrar con sus manos en una tierra predestinada." Tocqueville (1989: 35-36).

Pero esos primerísimos colonos de New England, no sólo eran el resultado de la selección llevada a cabo entre las clases medias inglesas por el calvinismo más fanatizado, sino también entre aquellos ingleses que tenían experiencia directa en la lucha política revolucionaria que (sin precedentes históricos conocidos) estaba viviendo la Inglaterra del momento.

La formación de las ciudades de Nueva Inglaterra siguió desde el principio este modelo: una determinada congregación religiosa separada, adquiría de los indios, por medio de compra, formalizada en documento por escrito, un cuadrado de tierra de 6 millas por cada lado. Se distribuían las tierras igualitariamente entre hermanos cuyas costumbres fueran de comprobada santidad, reservándose propiedades del común a efectos de gobierno público. Se procedía entonces a institucionalizar una genuina democracia municipal, esto es: la votación en Asamblea de cualesquiera asuntos públicos, elección de funcionarios anuales del gobierno, jurado popular, fijación de impuestos, decisión de gastos, elección de oficiales armados, instrucción pública de los niños ${ }^{31}$, etc. etc.

\footnotetext{
31 "Pero es en las disposiciones relativas a la educación pública donde se revela con toda claridad, desde el comienzo, el carácter original de la civilización americana:
}

'Considerando, dice la ley, que Satanás, el enemigo del género humano, encuentra en la ignorancia de los hombres las armas más poderosas y que es importante que las luces que trajeron nuestros padres no permanezcan sepultadas en sus tumbas; -considerando que la educación de los niños es uno de los primeros intereses del Estado, con la ayuda del Señor...' 
Cuando el crecimiento demográfico o inmigratorio así lo exigían, o las pendencias teológicas así lo aconsejaban, una nueva congregación, un nuevo enjambre, creaba una nueva colonia, hacia el Oeste, replicando (con mayor perfección) todo el proceso.

Importa mucho a nuestro argumento, no ya en esta parte en la que tratamos de los años formativos de las sociedades coloniales inglesas, sino en todo él, en todas y cada una de sus partes, historiográficas y sociológicas, comprender y aceptar y darle todo el enorme (decisivo) peso que tiene, a esto que sigue: que en esas sociedades coloniales inglesas y en las norteamericanas que en ellas se gestaron, nunca hubo campesinos, nunca hubo presencia de, nunca se puso en práctica la, sociabilidad feudal, esa sociabilidad nobiliar y servil, que fue construyendo durante siglos a todas las demás sociedades occidentales (incluso -aunque malamente a raíz de la conquista normanda- a Inglaterra). Excepcionalidad, singularidad ésta, de las sociedades norteamericanas, de no haber tenido pasado feudal, rasgo estructural único y exclusivo, que hace que solo ellas (entre las occidentales) merezcan propiamente el apodo de modernas. Porque si bien cualesquiera otras sociedades del planeta pueden modernizarse, y de hecho lo hacen, solo las de los Estados Unidos son verdaderamente modernas, por serlo desde su mismo origen, desde su misma fundación.

Pero no somos nosotros quienes lo decimos, sino que la mirada católicoaristocrática de Alexis de Tocqueville detectó fácilmente tan peculiar distinción norteamericana:

"Los americanos no hacen uso de la palabra campesino; no emplean la palabra porque carecen de la idea. La ignorancia de las primeras épocas, la simplicidad de los campos, la rusticidad de la aldea no se han conservado entre ellos y no conciben ni las virtudes, ni los vicios, ni los hábitos groseros ni las gracias ingenuas de una civilización naciente.

En los límites extremos de los Estados confederados, en los confines de la sociedad y de los desiertos (wilderness), existe una población de audaces aventureros que, para huir de la pobreza pronta a alcanzarlos bajo el techo paterno, no ha temido internarse en las soledades de América y buscar en ellas una nueva patria. Apenas llegado al lugar que debe servirle de asilo, el pionero abate enseguida algunos árboles y construye una cabaña bajo el follaje. No hay nada que ofrezca un aspecto más miserable que esas moradas aisladas. El viajero que se acerca a ellas al atardecer ve brillar de lejos, a través de los

Siguen unas disposiciones creando escuelas en todos los municipios y obligando a los vecinos al sostenimiento de las mismas, bajo pena de fuertes multas. Del mismo modo, se crean escuelas superiores en los distritos más populosos. Los magistrados municipales deben cuidar de que los padres envíen sus hijos a las escuelas; tienen derecho a multar a los que se resistan a ello, y si persiste su resistencia, la sociedad, sustituyendo a la familia, se apodera del niño y quita a los padres los derechos que le dio la naturaleza, pero de los que tan mal uso hicieran. El lector habrá sin duda observado el preámbulo de las ordenanzas. En América es la religión la que lleva a la ilustración, es la observación de las leyes divinas lo que lleva al hombre a la libertad." Tocqueville (1989: 42). 
muros, las llamas del hogar y por la noche, si llega a levantarse el viento, oye moverse ruidosamente el techo de follaje en medio de los árboles del bosque. ¿Quién no creería que esa pobre cabaña sirve de asilo a la ordinariez y la ignorancia? Sin embargo, no hay que establecer ninguna relación entre el pionero y el lugar que le sirve de cobijo. Todo es primitivo y salvaje a su alrededor, pero él es, por así decir, el resultado de dieciocho siglos de trabajos y experiencia. Lleva ropas de ciudad y habla su lenguaje. Conoce el pasado, es curioso del porvenir, argumenta sobre el presente. Es un hombre muy civilizado que se somete por un tiempo a vivir en el medio de los bosques y se interna en los desiertos del Nuevo Mundo con la Biblia, un hacha y algunos periódicos." Tocqueville (1989: 293).

Naturalmente, eso no quiere decir que no hubiese agricultura, pues dado el desarrollo de las fuerzas productivas en el siglo XVII, la agricultura era por fuerza la actividad más común entre los colonos ingleses, pero su agricultura fue desde un principio una agricultura comercializada, mercantil, orientada en su producción para la venta, contratando mano de obra asalariada (tenant servants), sometida la tierra a la compraventa, muy pronto a la especulación urbanística, etc. etc. ${ }^{32}$

Esto explica muchas cosas, tiene consecuencias profundas y extensas para cualquier estudio sociológico (presente o futuro) de esas sociedades norteamericanas. Pero aquí vamos a decir solo tres de ellas, encabalgadas entre sí, y muy directamente relacionadas con nuestra argumentación: primero, una apabullante (desconocida en la historia humana) prosperidad y abundancia económica, acompañó y acompaña el desarrollo de las colonias inglesas y las sociedades norteamericanas desde su misma fundación hasta nuestros días ${ }^{33}$. Segundo: los americanos fueron ciudadanos libres -libres (queremos decir) en el sentido estricto de las libertades propias de la sociabilidad capitalista, es decir: gobernados por Asambleas elegidas por ellos mismos-; fueron ciudadanos libres, digo, desde siempre: desde el mero principio de sus sociedades.

Ni el nombramiento por el Rey de Inglaterra de sus gobernadores fue nunca capaz de importunar el funcionamiento prácticamente plenipotenciario de dichas Asambleas Coloniales, al contrario: aquellos tenían que echar mano de estas si querían obtener algún resultado efectivo con su gobierno; ni tampoco el intento de limitar las Asambleas a los Santos o True Believers ${ }^{34}$ pudo mantenerse más allá de la tercera generación de puritanos, so pena de perder

\footnotetext{
32 "It will be found that English political economy and English popular notions are very deeply and extensively pervaded by the assumption that all property has been acquired through and original transaction of purchase. This strange and unique system of highly individual, impartible, property was unknown in the world before the twelfth century. For mysterious reasons it emerged in England alone. The consequences were immense: From very early times landed property changed hands by purchase and sale more frequently in England than elsewhere. Furthermore 'we are indebted to the peculiarly absolute English form of ownership for such an achievement as the cultivation of the soil of North America."

Sir Henry Main, 1883, citado en Macfarlane (1978: 187-8).

${ }^{33}$ Véase por ejemplo Potter (1965)

${ }^{34}$ Cfr. Hoffer (2009).
} 
el control político de las colonias que con tanto sacrificio habían fundado, siempre amenazado por la salvaje incorporación de más y más colonos, ya no ingleses, escoceses o irlandeses, sino europeos de todas las naciones, colonos que asumido el doble y concomitante modelo inglés, de capitalismo privado y gobierno por asambleas representativas, replicaban sin cesar nuevas colonias (cada vez más perfeccionadas) hacia la Frontera:

"The most dramatic adjustment the Puritans made in the New World was the adoption in 1662 of the Half-Way Covenant by the Massachusetts Synod, confirming an agreement made by the Ministerial Association in 1657. The Covenant enabled members of the church, after professing a godly life, to have their children baptized, and thus associated with the church. The importance of this concession can only be comprehended if seen against the backdrop of Puritan theology. A proved conversion experience or demonstrated regeneracy entitled a person to membership in the church covenant. Children of church members could be baptized, for they were assumed to be somewhat within the covenant, but baptism did not entitle the new generation of Puritans to full membership unless they, too, enjoyed a conversion experience. Therefore, the question arose, Should the children of these baptized members, in turn, be baptized? Under the terms of the Half-Way Covenant, baptism of these children (third-generation New World Puritans) was permitted, giving them partial membership in the church although they could not receive all the sacraments. This step signified that the Puritan Church, henceforth, would not be composed exclusively of the visible saints, that is, those men and women who, because of a demonstrated conversion experience, has presumably entered into the convenant of grace and thus were the elect, the saved." Versteeg (1964: 85).

Lo que tanta sangre había costado en Inglaterra, se convirtió, con toda naturalidad, en el punto de partida que se daba por supuesto en sus colonias.

$Y$ tercero, y sobre todo, es esa sociabilidad no mezclada, esa sociabilidad solo capitalista, la que explica, junto con algunos rasgos culturales ingleses, de raíces históricas profundas, el rasgo distintivo por antonomasia de las sociedades coloniales inglesas y estatales norteamericanas, a saber: su infatigable depredación y trespassing de toda Frontera.

Pero dejemos para más adelante el enjuiciamiento sociológico que nos merece esa Frontera, esa herida Normanda en el corazón Anglo (cuyas profundas raíces históricas y culturales en este escrito tan solo hemos empezado a vislumbrar)... y volvamos por lo de pronto a lo que ahora nos ocupa, reconociendo de plano (como hacían los propios colonos) que ahí sí, en tratándose de la Frontera, de la defensa y expansión de la Frontera, los colonos dependían totalmente de la voluntad y de la fuerza de la Corona Británica, pues solo ella era capaz de hacer frente a la calculada presencia militar francesa, que en un gran arco terrestre o Continental, unía o pretendía unir Québec con Nueva Orleáns, frenando, a mediados del siglo XVIII, el frenesí colonizador inglés, que exploraba impaciente las fértiles y enormes cuencas de los ríos Ohio y Missisipi. Esos asentamientos franceses eran débiles civilmente, es cierto, pero habían sido estratégicamente fundados para envolver militarmente a las Colonias Británicas, sobre todo a New England y New York, ésta última a través de sus aliados, los poderosos Iroquois. 
Pero tanto Francia como Gran Bretaña, en sus sucesivos enfrentamientos a los largo del siglo XVIII por la supremacía en Europa, habían terminado por reconocer que el control del Centro del Continente Norte Americano no era un baza menor, sino tal vez la que podía inclinar la balanza hacia un lado o el otro. Y así, entre 1755 y 1763 se desarrolla ante la atenta experiencia y mirada de los colonos, lo que los ingleses llaman The Great War for Empire, que se decide con la toma de Québec por un exaltado oficial inglés de 33 años, James Wolfe, que no vivió para contarlo. Tras la caída de Montreal, en el otoño de 1760, Gran Bretaña dominaba el centro del Continente Norte Americano, y era ya el máximo poder mundial.

\section{Electorado ad hoc}

A los ojos de los colonos, naturalmente, la eliminación de la amenaza francesa al Oeste (y con ella de la Iraquois) lo cambiaba todo. Antes de la Gran Guerra por el Imperio, en 1754, ya Franklin había propuesto en una reunión de representantes de las Colonias en Albany, un Plan of Union, pero la respuesta fue indiferente, cuando no hostil ${ }^{35}$. Ahora, después de la derrota francesa, todo un Continente esperaba al Oeste a los audaces que fueran capaces de imaginarlo, de "pensar continentalmente" como decía Hamilton,... y de arrebatárselo (a Londres)...

Como ya Cromwell había enseñado, lo decisivo aquí era conseguir una declaración de guerra por parte de Gran Bretaña, cosa nada difícil en la cultura política anglonormanda, pues sólo había que enfrentar la legitimidad de las Asambleas Coloniales (votadas por los colonos) con la legitimidad de Los Comunes (en los que no estaban representados), que desde la llamada Restauración de 1660 mandaban de facto en el Imperio Británico. Por otro lado este cuerpo político, Los Comunes, no estaba en absoluto acostumbrado a que se les hablase de igual a igual, era (como sabemos) un cuerpo político bigoted y omnipotente, que se tenía (aunque no lo decía) como la máxima expresión de la moralidad pública, y que era (y esto sí lo decía) "parte del máximo poder ilimitado de la nación". De manera que cuando los americanos -directamente, unánimemente, y apasionadamente- se negaron a pagar, en 1765 , algunos impuestos comerciales, los británicos amenazaron con cerrar el puerto de Boston.

Pero entonces, un colono, en uno de los muchos textos y panfletos revolucionarios que profusamente circulaban, pudo preguntarse:

"Cuando un miembro de la Cámara de los Comunes declara con seguridad que tiene poder para limitar nuestro comercio y restringir nuestras mercancías, me encantaría saber si obtuvo ese poder de sus electores, hombres libres honestos (...) De estos electores no pudo recibir más poder del que naturalmente poseían."36

\footnotetext{
${ }^{35}$ Cfr. Versteeg (1964).

${ }^{36}$ William Hicks, 1768, citado (con cursivas) por Morgan (2006: 256).
} 
El Ilamado Congreso Continental -una reunión de representantes de las Asambleas Coloniales de representantes- se reunió en Philadelphia el 5 de Septiembre de 1774, y denunció los impuestos aprobados por Londres (no taxation without representation) y la presencia (sin consentimiento) de tropas británicas en las Colonias. Lo que venía siendo más que habitual (e incluso bienvenido) se presentaba ahora como motivo de agravio. Patrick Henry, George Washington, John y Samuel Adams, John Jay, John Dickinson, nombres todos destinados a hacerse universalmente famosos, estaban entre las firmas reivindicadoras. Estallada la guerra, el 15 de Abril de 1775, en un segundo Congreso Continental reunido en el mes de mayo en Pensilvania, y al que se añadieron, entre otros, Benjamín Franklin y Thomas Jefferson, se hizo una muy escueta y muy celebrada Unánime Declaración de Independencia de Los Estados Unidos de América, que con el tiempo habría de convertirse en la base inexcusable de toda La Nueva Narrativa política moderna:

"When in the Course of human events, it becomes necessary for one people to dissolve the political bands which have connected them with another, and to assume among the powers of the earth, the separate and equal station to which the Laws of Nature and of Nature's God entitle them, a decent respect to the opinions of mankind requires that they should declare the causes which impel them to separation.--We hold these truths to be self-evident, that all men are created equal, that they are endowed by their Creator with certain unalienable Rights, that among these are Life, Liberty and the pursuit of Happiness.-That to secure theses rights, Governments are instituted among Men, deriving their just powers from the consent of the governed. That whenever any Form of Government becomes destructive of these ends, it is the Right of the People to alter or to abolish it, and to institute new Government, laying its foundation on such principles and organizing its powers in such form, as to them shall seem most likely to effect their Safety and Happiness.

Prudence, indeed, will dictate that Governments long established should not be changed for light and transient causes; and accordingly all experience hath shown, that mankind are more disposed to suffer, while evils are sufferable, that to right themselves by abolishing the forms to which they are accustomed. But when a long train of abuses and usurpations, pursuing invariably the same Object evinces a design to reduce them to under absolute Despotism, it is their right, it is their duty, to throw off such Government, and to provide new Guards for their future security.-Such has been the patient sufferance of these Colonies; and such is now the necessity which constrains them to alter their former Systems of Government. The history of the present King of Great Britain is a history of repeated injuries and usurpations, all having direct object the establishment of an absolute Tyranny over these States."

Sigue a continuación una larga lista de agravios causados en América por los británicos y su tiránico Rey, pero también una amarga y sentida queja dirigida al pueblo de Gran Bretaña, "a nuestros hermanos", porque "ellos también han sido sordos a la voz de la justicia y de la consanguinidad", para concluir:

"We, therefore, the Representatives of the United States of America, in General Congress, Assembled, appealing to the Supreme Judge of the world for the 
rectitude of our intentions, do, in the Name, and by the Authority of the good People of these Colonies, solemnly publish and declare, That these United Colonies are, and of Right ought to be Free and Independent States; that they are Absolved from Allegiance to the British Crown, and that all political connection between them and the State of Great Britain, is and ought to be totally dissolved; and that as Free and Independent States, they have full Power to Levy War, conclude Peace, contract Alliances, establish Commerce, and to do all other Acts and Things which Independent States may of right do.-And for the support of this Declaration, with a firm reliance on the protection of Divine Providence, we mutually pledge to each other our Lives, our Fortunes and our sacred Honor." 37

(Pero dejemos para otro momento -para otro momento más sociológico- el comentario atento que pueda merecer tan afamado y sacralizado texto verdadera piedra de toque que evalúa al resto de las democracias del mundo-, y volvamos por lo de pronto a la penúltima de nuestras arriesgadas acuarelas historiográficas).

Pues incluso para la poderosa Gran Bretaña de 1775, mantener y ganar una guerra a $5.000 \mathrm{Km}$ de distancia no era fácil, y menos cuando esa guerra se desarrollaba lejos de las costas, adentrada en el Continente. Por otro lado los colonos eran abrumadoramente hostiles a los Casacas Rojas, y Francia muy pronto, y España más tarde, apoyaron decididamente (sobre todo Francia en la guerra naval) a la autoproclamada nueva nación. Y así fue que el general Washington, al frente de La Continental Army, y hombres de acción como Arnold, Greene, y Morgan, al frente de sus respectivas Militias, perfectas conocedoras del terreno, doblegaron finalmente a los ejércitos británicos. Por la Paz de Paris, firmada el 3 de Septiembre de 1783, Londres reconocía la independencia de Los Estados Unidos, y sus límites occidentales, fijados en el Río Mississipi.

Pero he aquí que desprovistas de la tutela Real, las antiguas 13 colonias, ahora estados débilmente confederados, afrontaron tras la guerra una época incierta y convulsa. Mucho se había insistido, por John Adams y otros, en que una Asamblea debía ser como un retrato en pequeño de la sociedad a la que legislaba, que debía estar compuesta por representantes que "deben pensar, sentir, razonar y actuar" como la gente a la que representan, que sus diputados debían ser "del vecindario" Morgan $(2006,255)$. Y eso exactamente es lo que habían hecho los colonos en los años de la revolución y de la guerra, votar, elegir, para sentarse en sus Asambleas, a los hombres más comunes, que no hablaban la lengua de los abogados, de los comerciantes o de los grandes terratenientes, sino hombres en cambio muy parecidos a ellos mismos, que conocían cómo manejar una granja pequeña, o cómo mantener alejados a los cobradores de impuestos.

Pero esos hombres resultaron ser demasiado representativos, pues:

"Aprobaban leyes apresuradamente y las revocaban con la misma premura. Aprobaron leyes violando el tratado con Gran Bretaña, demoraron o redujeron

\footnotetext{
${ }^{37}$ Encilopaedia Britannica On-line. Article: Declaration of Independence
} 
el pago de deudas públicas o privadas, imprimieron papel moneda como moneda de curso legal, se negaron a pagar las cuotas de los gastos nacionales correspondientes a sus estados, subieron sus propios sueldos y bajaron los de otros funcionarios del gobierno." Morgan (2006: 268).

Naturalmente, los gigantes precursores de la Revolución, los Adam, Mason, Stuart, Jefferson etc. etc. sinceramente comprometidos con los valores republicanos, y con la nueva nación, cuyo destino (a sus ojos) manifiesto era encarnar dichos valores genuinamente, 'para que su ejemplo cundiera por toda la humanidad'. Esos gigantes vencedores de la guerra, digo, envueltos como estaban en las grandes palabras arrebatadoras, que abducen el alma del hombre desde la Primera Persona del Singular (YO) hasta la Primera Persona del Plural -elevándola a ese NOSOTROS, a ese locus mágico donde residen la igualdad de derechos, la justa repartición de los bienes sociales, la destrucción de todos los abusos, y qué sé yo qué otros Seres y Quimeras... Esos gigantes, digo, Jefes de la Revolución, estaban a la altura de los 1780', decepcionados y angustiados por la creciente impotencia del Congreso para poner coto a las locuras y desmanes de esas Asambleas Estatales, dominadas por hombres comunes, demasiado comunes, y solían escribirse entre ellos y quejarse, como hizo George Mason, de Virginia, en una carta a un amigo:

"(...) las frecuentes interferencias con la propiedad privada y los contratos; las leyes retrospectivas destructoras de toda confianza pública, tanto como de la confianza entre hombre y hombre y las violaciones flagrantes de la Constitución deben repugnar a la mejor y más sabia parte de la comunidad, ocasionan una gran decadencia de las formas, producen el desprecio a la legislatura, y finalmente provocan la anarquía y la conmoción pública." Morgan (2006: 268).

Sí, esas Asambleas Provinciales, sin una autoridad externa a ellas, que las limitase, no servían para unificar la acción ciudadana, no al menos todo lo que demandaba el evidente potencial de la Nueva Nación. O al menos eso pensaron aquellos hombres prestigiosos y poderosos, los Jefes de la Revolución, que la habían encabezado y llevado a buen puerto. Pues aunque idealistas, ante todo eran norteamericanos, es decir, ingleses trasplantados a la wilderness del Nuevo Mundo, y por eso mismo hombres resolutivos, que sólo se preguntaban una cosa: ¿Qué hacer? ¿Qué hacer para no perder en la paz lo ganado en la guerra?

En la Convención reunida en Philadelphia en el verano de 1787 con la intención de redactar una Constitución o Ley Suprema que obligara a todos los estadounidenses, Madison y otros plantearon que el que un colono votara para elegir a sus representantes en la Asamblea de su Estado, no le impedía el que pudiera votar para elegir a sus representantes en otra Asamblea, la de la Nación, que podía perfectamente -en impecable doctrina democrática- crearse ad hoc.

Se trataba, en pocas palabras, de echarle encima al electorado de cada Estado el electorado de todos los estados juntos (incluido el mismo). Que el poder de una Asamblea Nacional limitara el poder de cada Asamblea Estatal. 
De modo que los 55 delegados de las Legislaturas Estatales allí reunidos llegaron, a propuesta del Estado de Connecticut, a un Gran Compromiso: a saber: que todos los hombres de los estados norteamericanos, participarían conjuntamente -considerados un solo electorado- en la elección de dos cámaras: una llamada Casa de Representantes, en la que cada estado tendría tantos asientos como le correspondiese en proporción a su población libre (a la que se añadía también $3 / 5$ de su población esclava); y otra llamada Senado, a razón de 2 representantes por cada estado, con independencia de su tamaño y población.

Aclarado esto, el texto pudo avanzar entonces en la definición -recíprocamente referida- de los poderes Legislativo, Presidencial y Judicial; en la enumeración y blindaje de los poderes de la Nación respecto de los residuales o reservados de los Estados; explicita posteriormente (1791) los derechos inalienables (en realidad no otra cosa que los emprácticos) de la ciudadanía; los procedimientos de enmienda de la propia Constitución; otorga al Poder Judicial (en acertada previsión de futuros e innumerables conflictos) la facultad de revisar la constitucionalidad o no de las leyes de la Nación o de los estados; etc. etc. La Constitución, en fin, en su artículo VI, se cita a sí misma como "the supreme Law of the Land;... any Thing in the Constitution or Laws of any State to the Contrary notwithstanding."

Es así como esos 55 delegados de las Asambleas de representantes de los Estados, en el verano de 1787, otorgaron poderes decisivos a un nuevo electorado, antes impensado, inexistente, al que ellos mismos crearon porque definieron (con hábil e intencionado rigor jurídico). Pero ese electorado existía, no era sino el resultado del doble substrato común a los antaño colonos ingleses, que en efecto permitía ya por entonces (aunque no tanto como ahora) definirlos como el electorado (casi estamos tentados a decir el pueblo) norteamericano: por un lado, todos eran hijos de una misma cultura política, de raíz anglonormada (incluso los esclavistas sureños). Y por el otro, todos eran también individuos investidos por una misma sociabilidad ciudadana (capitalista), que existía diseminada aún por los más solitarios desiertos (Tocqueville).

Que esto es así, que existía efectivamente esa ciudadanía común y distintiva norteamericana, lo demuestra sin más el hecho de que tan solo un año más tarde, en junio de 1788, ya las Asambleas Estatales habían ratificado la Ley suprema que la Convención Constitucional les había enviado; y que antes de acabar ese mismo año, 1788, se convocan elecciones, que fueron masivamente respaldadas, y se puso en marcha el primer gobierno constitucional de Los Estados Unidos de Norteamérica. El Coloso echaba a andar. $^{38}$

\footnotetext{
${ }^{38}$ ¡Y qué gran círculo! -mejor dicho iqué gran Banda de Möbius!.. ¡Por entero incesantemente recorrida!-. En todo caso ¡qué prodigioso peregrinar protagonizado durante 700 años por esa singular y vigorosa cultura política anglonormanda, desde la Conquista de Guillermo en 1066 hasta la Constitución de los USA en 1787! Pues ha sabido transformar una narración puramente medieval, feudal, que depositaba en Dios la fuente última de la Soberanía, haciendo a la Iglesia Católica su depositario más cercano, que delegaba a su vez en los Reyes; hasta esta narración moderna, ciudadana, en la que (al menos nominalmente) se sigue considerando a Dios la fuente última de la Soberanía, pero en cambio, y esto es lo que importa, se considera
} 


\section{Not so wild wild West}

Una de las cosas más primordiales e importantes (sino la más) que resolvía La Constitución, era definir jurídicamente el procedimiento de formación de nuevos estados al Oeste, evitando que los antiguos y orgullosos estados del Este se pelearan entre ellos por el botín de guerra (de la guerra habida con Inglaterra). $Y$ es que en contra de la propia narración, en contra de la propia épica individualista que tanto les gusta contarse a sí mismos a los norteamericanos, fue gracias a ese avanzadísimo y sofisticadísimo artilugio político-administrativo genuinamente americano, que funciona simultáneamente a tres niveles, a saber: la democracia municipal, la Legislatura estatal, y el Congreso federal, con competencias recíprocas jurídicamente definidas, y electoralmente respaldadas; fue gracias, digo, a la unidad de acción de ciudadanos obedientes a Asambleas que ellos mismos eligen, que se pudo producir y administrar esa rápida e incesante replicación hacia el Oeste del mercantilismo (capitalismo) fundador de todas las localidades americanas:

"Under the belief that all men going into vacant lands have the right to shape their own political institutions, the riflemen of western Virginia, western Pennsylvania, Kentucky and Tennessee, during the Revolution, protested against the rule of governments east of the mountains, and asserted with manly independence their right to self-government. But it is significant that in making this assertion, they at the same time petitioned congress to admit them to the sisterhood of States. Even when leaders like Wilkinson were attempting to induce Kentucky to act as an independent nation, the national spirit of the people as a whole led them to delay until at last they found themselves a State of the new Union. This recognition of the paramount authority of congress and this demand for self-government under that authority, constitute the foundations of the federal territory system, as expressed in congressional resolutions, worked out tentatively in Jefferson's Ordinance of 1784 , and finally shaped in the Ordinance of 1787." Turner (1958: 169).

Es lógico entonces que para esa cultura fronteriza, ciudadana-norteamericana, las sociabilidades feudales ( $y$ ya no digamos otras sociabilidades tribales, 0 tribales reconstituidas), no han inspirado nunca -en su conciencia colectiva, digo- otra cosa que indiferencia, cuando no desprecio:

"The stubborn American environment is there with its imperious summons to accept its conditions; the inherited ways of doing things are also there; and yet, in spite of environment, an in spite of custom, each frontier did indeed furnish a new field of opportunity, a gate of escape from the bondage of the past; and

dicha Soberanía fehacientemente depositada 'en El Pueblo', que delega algunos de sus poderes en una Asamblea que el mismo elige.

Esta narrativa contemporánea de la Soberanía Nacional nos parece más creíble (porque es la nuestra). Pero los asuntos humanos siguen su curso incesante, su Historia, y no ha de ser la última ficción política que inventemos (aunque si ha de ser la última que nosotros, los que vivimos, conozcamos). Tal vez tengamos muy al final que volver sobre todo esto. 
freshness, and confidence, and scorn of older society, impatience of its restraints and its ideas, and indifference to its lessons, have accompanied the frontier." Turner (1958: 38) [cursivas nuestras]

No se trata de que los americanos tengan sólo 400 años de historia, como suele decirse, sino que llevan ya 400 años echándose la Historia a la espalda, que es cosa bien distinta. Además, esa Conquista del Oeste no es cosa del pasado, sino que sigue hoy en día tan activa como siempre, ya que si en su origen solo podía realizarse por medio del único recurso productivo por entonces al alcance de los emigrantes, la agricultura, con el desplazamiento de la Frontera hacia el Pacífico, ahora continua produciéndose -en términos sociológicos equivalentes-, con la incesante invención de tecnológicas pioneras en las grandes multinacionales norteamericanas, que buscan y logran desplazarse infatigablemente hacia el centro del mercado (mundial).

"La esfera de la circulación o del intercambio de mercancías, dentro de cuyos límites se efectúa la compra y la venta de la fuerza de trabajo, era, en realidad, un verdadero Edén de los derechos humanos innatos. Lo que allí imperaba era la libertad, la igualdad, la propiedad y Bentham. ;Libertad!, porque el comprador y el vendedor de una mercancía, por ejemplo de la fuerza de trabajo, sólo están determinados por su libre voluntad. Celebran su contrato como personas libres, jurídicamente iguales. El contrato es el resultado final en el que sus voluntades confluyen en una expresión jurídica común. ¡lgualdad!, porque solo se relacionan entre sí en cuanto poseedores de mercancías, e intercambian equivalente por equivalente. ¡Propiedad!, porque cada uno dispone solo de lo suyo. ¡Bentham!, porque cada uno de los dos se ocupa solo de sí mismo. El único poder que los reúne y los pone en relación es el de su egoísmo, el de su ventaja personal, el de sus intereses privados. Y precisamente porque cada uno sólo se preocupa por sí mismo y ninguno por el otro, ejecutan todos, en virtud de una armonía preestablecida de las cosas o bajo los auspicios de una providencia omniastuta, solamente la obra de su provecho recíproco, de su altruismo, de su interés colectivo." [Cursivas del texto]

El Capital, Karl Marx, 1867

\section{Individualismo}

1. Volvamos a la Sociología. El objetivo ahora es comprender de qué modo aquella individuación empráctica, que ya dijimos (vid. supra II.) nos afecta a todos los que bregamos día tras día en el mercado (o en su administración), se inviste de valor moral, convirtiéndose en exaltado individualismo, en el más celebrado principio de nuestra organización social.

Para ello tenemos que hacer aquí explícito el concepto de estructura social, que desde hace años (con peor o mejor fortuna) venimos construyendo. Del conjunto todo de las prácticas sociales que son propias de la sociabilidad de nuestras clases medias, en los países de Europa Occidental, tres hay que se 
distinguen por que son co-extensivas a dicha sociabilidad, pues nos abarcan y nos alcanzan -lo queramos o no- a todos y cada uno de nosotros sin excepción. Esas tres prácticas sociales que (repito) nos son co-extensivas, son, en primer lugar, las empresas capitalistas privadas en las que trabajamos, entrelazadas entre sí en mercados siempre expansivos $\left({ }^{\wedge}\right)$. En segundo lugar, las relaciones sexuales y de crianza, que (tendencialmente) vamos estableciendo cada vez más al margen o en las afueras de las organizaciones escolares y profesionales, lo que se ha venido en llamar 'nuevas' familias. Y en tercer lugar, las administraciones del Estado, cuyas burocracias interpelan muchos ámbitos de nuestra vida social: escolarización, judicatura, legislación, fiscalidad, etc. etc.

Sin entrar ahora en demasiadas profundidades teóricas, esas tres prácticas sociales forman, decimos, una Estructura Social, un conjunto de intereses creados, recíprocamente referidos, eventualmente consolidados y hasta legalizados, que detentan y defienden las personas e instituciones titulares de dichos intereses y privilegios... conjunto de relaciones sociales que podría ser útil esquematizar así:

'nuevas' familias \empresas capitalistas ^

Funcionarios públicos

La relaciones entre esas prácticas sociales son diversas, y sólo señalaremos algunas que sean imprescindibles para nuestro argumento. Baste decir, por ahora, que la tremenda individuación que resulta de la privatización de la apropiación, consustancial al capitalismo, y que profesionaliza y escolariza de por vida a hombres, mujeres y niños, es (para el que esto escribe) concomitante con la avanzada liberación de nuestras relaciones sexuales y de crianza, que ya no se sujetan hoy en día casi a ninguna institucionalización patriarcal, sino que se rigen por las escuetas inclinaciones sentimentales de los individuos emparejados que incesantemente las atan (y desatan). O también, que solo el capitalismo privado ha sido históricamente capaz de generar impuestos bastantes como para sostener en nómina a millones (literalmente) de funcionarios públicos, que en contrapartida nos dedicamos objetivamente a replicar en todo momento su expansión, y a aminorar (en lo posible) los problemas sociales que el capitalismo va creando... ique no son pocos!

En el esquema aparecen más fuertemente separadas las administraciones públicas (por un lado) de las empresas y familias (que aparecen más juntas por el otro), porque en cierto modo esas prácticas funcionariales tienen algo de secundarias, ya que presuponen lógicamente la existencia de las de crianza (ya que son entre adultos) y empresariales (ya que financiadas vía impuestos)... pero a su vez éstas últimas difícilmente se hubiesen consolidado sin aquellas, etc. etc. ${ }^{39}$

Cabría también preguntarse ahora si hay algún rasgo estructural en la expansión de la dominación capitalista en el ámbito de la organización de la producción (que entre nosotros los europeos occidentales se ha completado

${ }^{39}$ El lector interesado puede ver Allones (1999a, 1999b). 
cabalmente), por el cual las cúpulas políticas de esas administraciones funcionariales debieran ser nombradas por asambleas elegidas por los ciudadanos que aquella expansión social precisamente ha ido históricamente incorporando. O sí, por el contrario, esa democratización de las cúspides del funcionariado es tan solo un resultado histórico, contingente, de la victoria aliada en la II Guerra Mundial.

Quizás las lógicas profundas de la representación asamblearia y de la individuación capitalista se refuercen recíprocamente en su expansión, como la historia inglesa parece ilustrar vivamente. O sea tal vez que las sociedades de masas, creadas por el capitalismo, reclaman primero la burocratización del Estado (como argumentaba Weber), y luego tendencialmente su democratización. O simplemente ocurre que el ciudadano quiere fiscalizar la recaudación y gasto de los impuestos que paga. Pero con todo, la pregunta siempre estará ahí, la cuestión de sí tales libertades políticas no son sino un resultado azaroso (y bien dichoso, por cierto) de la historia, historia que sería muy otra si, por ejemplo, los nazis hubiesen ganado la II Guerra Mundial...

Pero tal vez la cuestión así planteada no ayuda, y aún confunde, pues no sería la primera vez, ni ha de ser la última, en la evolución de las sociedades humanas, en la que un suceso histórico contingente termina por convertirse en un rasgo estructural de la vida social de quienes lo han experimentado, y aún más de sus descendientes, y es evidente que ninguno de los que disfrutamos hoy en día de las libertades democráticas, podemos ya imaginar siquiera vivir sin ellas... (Porque mucho criticamos en este escrito las libertades burguesas... pero mientras no consigamos superarlas ¡benditas sean!...)

Pues bien, sea porque la formalidad democrática se ajusta mejor a la expansión capitalista, o porque las demás naciones tuvieron que replicarla como único modo de hacer frente a las eficaces políticas expansionistas inglesa y norteamericana, o porque éstas pujantes naciones la impusieron a los países derrotados en la II Guerra, o por todas o algunas de estas causas juntas o separadas... el caso es que en Europa Occidental todos hemos terminado por desarrollar un capitalismo avanzado, y a la par, sistemas políticos democráticos: esto es: sistemas en los que los altos cargos de las organizaciones de funcionarios de carrera del Estado son ocupados (generalmente) por políticos también de carrera, o profesionales, nombrados a lo último por asambleas que nosotros mismos elegimos...

¿Pero cómo han llegado esas asambleas a hacerse con la Soberanía efectiva en nuestras sociedades? ¿Por qué método o procedimiento formal se han alzado con el poder? Y sobre todo ¿qué Nueva Narrativa resultó de tal procedimiento? ¿Y qué tiene y qué no tiene (para el análisis) de verosímil esa Nueva Narrativa?

2. Por supuesto, mucho varían las condiciones sociales en las que se da, en las distintas sociedades, en los distintos períodos históricos, la lucha por parte de la ciudadanía para que el poder del Estado resida en una Asamblea que la represente. Pero de esas variadas condiciones, la que nos parece más presente y principal, es, como siempre, la propia fortaleza, centralidad, y 
madurez de la misma sociabilidad ciudadana, que necesita y se halla en condiciones de dar un salto histórico en su expansión. Empiezan entonces a proliferar, entre las clases medias, individuos pertenecientes a todos los ámbitos sociales -pero sobre todo funcionarios, sindicalistas, estudiantes, abogados, periodistas, algún que otro empresario, etc. etc.-, que haciendo uso de las libertades de asociación, de opinión, de publicación, que en todas partes son inmanentes o emprácticas de tal ciudadanía capitalista, se dan a todo tipo de conspiraciones organizadas contra los actuales detentadores del poder, a los que acusan (no sin razón) de haberse apropiado del Estado por un acto de guerra, o de usarlo con abuso de la tradición o pérdida de su carisma. Los actuales mandatarios reaccionan lógicamente aumentando la represión sobre tales organizaciones (a las que declaran fuera de la ley o clandestinas), lo que produce en sus miembros un estado de fuerte exaltación sentimental, un estado religioso, en torno a Grandes Palabras, como Igualdad, Libertad, Pueblo, Nación, Derechos Humanos, Democracia... Palabras que precisamente por no significar nada en particular, precisamente porque son perfectas abstracciones, vacías de todo contenido, pues no se refieren sino a Ellas Mismas, pueden significar cualquier cosa, pueden ser eventualmente rellenadas con las peregrinas ensoñaciones preferidas de aquellos que por vez primera las oyen, y que a partir de entonces las repiten una y otra vez cual letanía, al comprobar el efecto de Mágica Fraternidad que (hasta cierto punto) producen en los demás.

Finalmente, el número de tales ciudadanos parlanchines (o concienciados), va alcanzando, en medio de décadas de persecuciones, cárceles, expropiaciones, muertes, una masa crítica suficiente, como para arrastrar también a la preocupación política a muchos de nosotros, la inmensa mayoría, que hasta entonces permanecíamos, si bien atentos (a nuestros intereses), con todo aún cautamente indiferentes (a la política). Por su parte, los actuales detentadores del Estado, terminan por reconocer, a regañadientes, su obsolescencia histórica, empezando a pensar entonces en las ventajas que podrían si acaso resultar (también para ellos) de la convocatoria de unas elecciones libres, a una Asamblea Constituyente -elecciones a las que todos ellos: los hasta ahora poderosos, y los que aspiran a llegar a serlo, desde luego se van a presentar...

Ahora que se han convocado esas primeras elecciones, las asociaciones políticas hasta entonces clandestinas, devienen partidos políticos legalizados, que concurren abiertamente para lograr para sí el mayor número posible de votos, y con ellos (proporcionalmente) el acceso a la mayor representación posible en la Asamblea que escribirá la nueva Constitución.

Para nosotros sociólogos, lo cierto es que es ha sido el apoderamiento social que han protagonizado durante décadas y décadas las clases medias dignificadas por la expansión capitalista-, que han alcanzado su actual protagonismo económico y prestigio social; ha sido esa gravedad y esa centralidad social ganada a pulso día a día en el mercado por las clases medias (y sus administraciones), digo, lo que objetivamente ha conseguido forzar por fin la convocatoria de tal Asamblea Constituyente, por lo que su función objetiva -más allá de las ensoñaciones particulares de los militantes políticos clandestinos- no es (no puede ser) sino la de garantizar, la de blindar, 
ahora con toda el peso de la Ley, respaldada por los Tribunales, la sociabilidad consuetudinaria, hasta entonces meramente empráctica, de dicha ciudadanía.

Por eso los partidos políticos que durante décadas, con gran riesgo y sufrimiento personal, se sacrificaron para democratizar el ejercicio de la soberanía, son percibidos como extremistas por los electores, obteniendo muy pobres resultados representativos, al contrario que los partidos prácticamente creados ex profeso, al hilo mismo de la convocatoria electoral, que cuanto menos hayan luchado por traer la democracia, mejores resultados tendrán.

El aviso llegará muy vivamente a los escasos partidos que logran efectivamente escaños en la Asamblea, que se avendrán ahora a pactar y escribir la nueva Regla del Juego, la Ley Constitucional por la que ellos mismos (u otros parecidos) han de regirse en el futuro para acceder a la cúspide de los empleos del poder. ${ }^{40}$

Todos esos partidos políticos tienen a gala distinguirse muy mucho de los antiguos detentadores del poder del Estado, sobre todo porque están de acuerdo en que esa Ley debe garantizar que solo el resultado electoral determinará proporcionalmente la representación en la Asamblea, y que esa Asamblea, a su vez, detentará a lo último -y hasta su renovación en las próximas elecciones- el poder de nombrar a todos los altos rangos en las administraciones de funcionarios del Estado.

Tras ésta Ley fundacional de la soberanía democrática -adjetivada así porque garantiza a la ciudadanía su interpelación periódica como electorado-, que blinda las atribuciones y limitaciones de la Asamblea electa, la Ley avanzará en la definición del Gobierno que de ella (o por un proceso electoral directo) se segregue, junto con la composición de los Tribunales ordinarios o ad hoc, ante los que cualquier ciudadano o institución podrá en el futuro dilucidar cualquier agravio o pleito entre competencias de las instituciones, competencias que han quedado así, por una misma y sola Ley, blindadas en sus relaciones recíprocas.

Esa Constitución pasará a ser considerada Ley Suprema o decisiva ante cualesquiera otras leyes vigentes, y fijará también los procedimientos (electoralmente exigentes) para su enmienda o modificación.

Redactada la Constitución, ésta primera Asamblea se disuelve, no sin convocar antes a la ciudadanía a un Referéndum para su rechazo o aprobación, para proceder, en caso de aprobación, a una nueva convocatoria electoral, esta vez para elegir una nueva Asamblea, que, como las sucesivas, actuará ya sujeta a los poderes y limitaciones que le ha otorgado la nueva Constitución, ahora vigente.

\footnotetext{
${ }^{40}$ Para el caso de la llamada transición política española, y desde un punto de vista fuertemente sociológico, véase el libro de Moya (1984). Este libro imprescindible, fue en su día inteligentemente silenciado por el periódico El PAíS, entre otros.
} 
3. De manera que ésta Nueva Narrativa, que es la nuestra, la que nos es contemporánea, reza así: la Soberanía reside en la ciudadanía, pero como ésta (dado su número) no puede gobernarse por sí misma, ha delegado su ejercicio cotidiano en sucesivas Asambleas, que ella misma elige cada 4 años.

Y ahora debemos preguntarnos, a la luz de nuestro análisis, ¿qué tiene de verosímil y que tiene de inverosímil dicha Narrativa?

Obviamente el electorado -los ciudadanos censados con derecho a votoejercen cada 4 años un efectivo poder sobre los programas y doctrinas de los Partidos. Estos, para realizar sus fines, de acceder a cuantos más cargos mejor, y ponerse al frente de los funcionarios de las multiplicadas administraciones del Estado, tienen (lo quieran o no) que adaptarse a los hábitos medios, afectivos e intelectuales, de dichos votantes, y ello así continuamente, no solo en período electoral explícitamente, sino implícitamente de continuo y siempre, so pena de no acceder o perder (esto es mucho peor) los cargos que ahora disfrutan. Esa constante atención al sentir ciudadano, ese temor a irritar a los votantes de cualquier condición, y perder o no ganar su preferencia, es una poderosa fuerza centrípeta que va afinando y uniformizando incansablemente los programas de todos los partidos, que se someten al inflexible deseo de las clases medias de expandir las condiciones sociales (de todo tipo) que son favorables a su sociabilidad (y en primerísimo lugar desde luego, la expansión misma del capitalismo, del PIB, que es la fuente misma de dicha sociabilidad). Solo así tales partidos han llegado a convertirse en verdaderos partidos de masas, verdaderas escuelas de burócratas, de funcionarios especializados en el cálculo electoral, que instintivamente rechazan cualquier programa, cualquier contenido, políticamente incorrecto.

De manera que cuando se nos dice que la Soberanía reside contemporáneamente en la ciudadanía, nosotros por lo hasta ahora dicho, pensamos que (a lo último) en efecto así es. Los votantes disciplinan a la larga férreamente los actos y dichos de los políticos que los gobiernan.

Sin embargo, esa afirmación demasiado drástica requiere en algo ser matizada, porque si bien los políticos necesitan a los votantes, también es cierto que los ciudadanos necesitan a los políticos (ya que los ciudadanos se cuentan por millones, cuando no por decenas o centenas de millones, y no pueden ejercer directamente el gobierno del Estado, por mera imposibilidad material). Y es ahí en donde se abre para los Partidos un efectivo espacio de libertad, una cierta (aunque relativa) capacidad de decisión, de diseño de aquellos contenidos de las políticas públicas que, por afectar a aspectos no substanciales, sino a fracturas superficiales de la vida social de las clases medias, pueden ser tentativamente, y cautamente explorados, por su eventual rentabilidad electoral (en la medida en que no cuestionen naturalmente lo principal: la expansión social de dichas clases).

Ocurra entonces por afinidad sentimental, o por cálculo electoral, o por ambas cosas a la vez, el caso es que algunos partidos insisten más en los valores familistas tradicionales, precisamente porque otros lo hacen en la legitimidad 
de las nuevas variedades de familias; mientras que unos pondrán mucho énfasis en la privatización de algunas administraciones hasta entonces públicas, otros propondrán ampliar las políticas llamadas sociales o de Bienestar; aquellos, en fin, se especializaran en excitar las diferencias culturales de algunos segmentos del electorado, a los fines de circunscribir el acceso a los cargos públicos para los que más se identifiquen con esas diferencias; etc. etc. $Y$ últimamente han tenido éxito también las llamadas terceras vías: políticos que presumen (como nosotros) de buen rollito, que alardean de querer cambiar la estructura social (en lo posible), sabiendo como saben perfectamente que no tenemos voluntad real alguna de hacerlo, y que por eso mismo gustan fingir como si de veras quisieran intentarlo... ( ¡Y cómo si estuviera en manos de los políticos el hacerlo!)...

Todo en fin vale en la lucha entre partidos, con tal de que haga posible el éxito electoral, siempre y cuando no amenace nuestra efectiva soberanía, aquella con la que, votación tras votación, nos garantizamos la expansión del capitalismo en la que se basa nuestra sociedad.

Por eso mismo, por esa limitación centrípeta, estructural, aquello mismo que los ha convertido en Partidos de masas (a saber, esa tendencial y calculada aproximación de todos ellos al centro de la campana de Gauss donde residen las sensibilidades políticas ciudadanas mayoritarias), es lo mismo que les impide ir demasiado lejos cuando tratan de diferenciarse entre sí... Entonces las luchas centrífugas entre ellos se van convirtiendo más y más en disputas intra-partidistas, por cuestiones cada vez más nimias, cuando no ridículas, que sólo interesan a aquellos que las protagonizan, los políticos profesionales, pero que nada nos dicen a la inmensa mayoría de nosotros, que las contemplamos indiferentes, cuando no aburridos, y hasta asqueados. Salvo, claro está, cuando, por creerse sus propias palabras, en su delirio, los políticos tocan asuntos de sustancia, que pudieran (por ejemplo) afectar a nuestro crecimiento económico. En ese caso, en sucesivas elecciones, se lo haremos pagar bien caro, pues esa clase de asuntos hace ya mucho tiempo que nosotros no consentimos que se toquen.

Nos quejamos de las horribles peleas que mantienen los políticos entre sí, pero somos nosotros quienes los hemos hecho horribles... tan horribles como nosotros.

4. Desde las nuevas catedrales, y desde la más antigua y señera de todas ellas (Westminster Hall), en los preámbulos de las leyes, y en las doctrinas de los partidos que en ellas se asientan, y en las imágenes y ruidos de los poderosos (y partidistas) media etc. etc. Se nos difunde una y otra vez el nuevo dogma, la nueva narración repetida por doquier con sospechosa insistencia, con prepotente soberbia y seguridad, aquello tan manido de que vivimos en una 'society of free individuals', en una 'free civilization', en una 'free society', 'a free and truly individualistic system', vivimos en una sociedad que se sustenta en 'the free colaboration of individuals', donde 'every man's will shall be as unfettered as possible' etc. etc. ${ }^{41}$

\footnotetext{
${ }^{41}$ Todas las expresiones citadas han sido recogidas del excelente artículo de F. A. Hayek, Individualism: True and False, tal y como aparece en su libro Hayek (1948: 1-32).
} 
En la boca de esos funcionarios, en los gestos de esos políticos, y de nosotros los profesores e intelectuales en nómina -y precisamente por estar en nómina, es decir: en una posición diferente, como funcionarios, en la estructura social, que la que tienen los asalariados, que trabajan en la empresa privada, y a los que se paga por su productividad, no como a nosotros, que se nos paga por nuestro rango:

'nuevas' familias / empresas capitalistas ^

Funcionarios públicos ${ }^{42}$

Y mirando desde nuestra privilegiada posición estructural de funcionarios, que nos garantiza el mensual cobro de nuestra actual nómina y futura pensión, por lo que tal individuación (en tanto que funcionarios) no nos alcanza tanto y nos duele mucho menos; y mirando hacia el dinamismo siempre expansivo de la circulación de todo tipo de mercancías (para eso se nos paga), y entre ellas también la que hace posible a todas las demás: la fuerza de trabajo; mirando, digo, desde la administración y cara al consumo, ¿qué es lo que se ve? Pero ya Marx se hizo parecida pregunta, y nos dejó escrita su famosísima respuesta:

"La esfera de la circulación o del intercambio de mercancías, dentro de cuyos límites se efectúa la compra y la venta de la fuerza de trabajo, era, en realidad, un verdadero Edén de los derechos humanos innatos. Lo que allí imperaba era la libertad, la igualdad, la propiedad y Bentham. iLibertad!, porque el comprador y el vendedor de una mercancía, por ejemplo de la fuerza de trabajo, sólo están determinados por su libre voluntad. Celebran su contrato como personas libres, jurídicamente iguales. El contrato es el resultado final en el que sus voluntades confluyen en una expresión jurídica común. ilgualdad!, porque solo se relacionan entre sí en cuanto poseedores de mercancías, e

Dicho artículo, escrito por Hayek en 1944, durante la II Guerra Mundial, para polemizar valientemente con el nazismo y con el estalinismo, y con algunas consecuencias (que él juzga nocivas) del racionalismo francés, ha sido sin embargo útil aquí para nosotros por motivos diferentes: por que en él hemos encontrado una perfeccionada e inteligente apología del capitalismo en general, y del parlamentarismo inglés en particular.

${ }^{42}$ Esa posición estructural diferenciada, de los actuales funcionarios públicos, nos recuerda bastante a la de los antiguos funcionarios, los curas, que para mejor administrar el patriarcado entre los campesinos se les prohibía formalmente participar en él, de la misma manera que ahora a nosotros los funcionarios, para mejor administrar el capitalismo entre los ciudadanos, se nos prohíbe formalmente participar en él. Y si los curas se saltaban una y otra vez el celibato, con la connivencia de todos sus feligreses e impunemente, también nosotros prevaricamos una y otra vez a nuestro favor en el mercado que administramos: médicos, pilotos, profesores, diputados, alcaldes, jueces, etc. etc. a todos se nos consiente todo tipo de abusos (por nuestros electorados sabedores), siempre que no puedan ser formalmente probados (y aún así...).

Nada nuevo bajo el sol: los poderosos (en cualquier sociedad humana) siempre se distinguen por la impunidad con la que cometen los crímenes que castigan en los demás... Véase sino el masivo desfalco bancario originado en Wall Street, responsable en gran parte de la actual crisis del sistema, y que nadie (yo tampoco) quiere nombrar ni juzgar a los culpables (por lo demás fácilmente rastreables en los archivos de los ordenadores con los que trabajaban), sino perdonarlos y refinanciarlos vía impuestos... ¡Cualquier cosa menos tener que condenarlos! 
intercambian equivalente por equivalente. ¡Propiedad!, porque cada uno dispone solo de lo suyo. ;Bentham!, porque cada uno de los dos se ocupa solo de sí mismo. El único poder que los reúne y los pone en relación es el de su egoísmo, el de su ventaja personal, el de sus intereses privados. Y precisamente porque cada uno sólo se preocupa por sí mismo y ninguno por el otro, ejecutan todos, en virtud de una armonía preestablecida de las cosas o bajo los auspicios de una providencia omniastuta, solamente la obra de su provecho recíproco, de su altruismo, de su interés colectivo." Marx (1975: 214). [Cursivas del texto; negritas nuestras] ${ }^{43}$

Es así como entre nosotros, los funcionarios, digo, y particularmente nosotros, los más intelectualizados entre nosotros, bien por oficio o por vocación, el Individualismo ha venido en convertirse en un Ente-Celestial, se ha desgajado, se ha separado de la galopante individuación social en la que día tras día, a pie de planta, en los polígonos industriales, en las oficinas, en los comercios, duramente se genera. El individualismo se ha elevado, se ha trascendido ahora en un nuevo Ente-A-Parte, que tiene vida propia, en un símbolo, en una fuente, en un faro que orienta, que guía estratégicamente mi acción en sociedad, precisamente porque los demás, todos los demás, también lo poseen, también lo comparten, creen en él y lo manejan... y así nos garantizo la comprensión de mis actos, me garantizamos el sentido, la plausibilidad y hasta la eficacia de los actos de todos los demás. Invocado el Gran Mantra, Freedom, todo el mundo enmudece ( $\mathrm{i} Y$ hay de quién no lo haga!). ${ }^{44}$

Pero claro, nosotros, sociólogos, como aguafiestas que somos, tenemos sin embargo la obligación de ver lo más objetivamente posible qué hay de cierto en

\footnotetext{
${ }^{43}$ Por lo demás, es muy gracioso que las leyes ciudadanas, propias y exclusivas de una particular sociabilidad (a saber: la capitalista) entre otras varias posibles sociabilidades humanas (del pasado, del presente, del futuro), quieran arrogarse el título de derechos humanos naturales, como si la naturaleza humana hubiera estado esperando ésta sociabilidad para realizarse, o como si no se hubiera realizado en otras (sospechamos que mejor) o no pudiera realizarse en otras (que hubo, que hay, que habrá).

Es típico, desde luego, de todo sistema social, la naturalización de las relaciones estructurales que precisa para su reproducción (también las Iglesias de todo signo lo han hecho y lo hacen): cójanse las clases medias norteamericanas de los años 1950', proyéctense 1.000 .000 de años atrás, iy aparecen Los Picapiedra!... Con lo cual el modo de vida de esas clases medias queda naturalizado, legitimado.

Pero desde luego, esta naturalización de nuestras libertades como las únicas libertades sociales conforme a natura, nos muestra (una vez más) lo estrechos que son los límites epistemológicos de nuestros parlamentos.

44 "Estando dirigidos a millones de almas, los medios deben, necesariamente, evitar la consideración de temas que interesan solo a los miles o a los cientos. Esto implica un peligro para la libertad de expresión, pero no precisamente el peligro contra el cual los guardianes de nuestras libertades están generalmente poniéndonos sobre aviso. Estos temen que los grandes editores y anunciantes -que manejan un poder autocrático- supriman cruelmente las ideas de las minorías. La dinámica del mercado de masas, sin embargo, parecería indicar que la libertad de expresión tiene menos que temer del control que ejercen los grandes anunciantes que del control de dichos anunciantes permiten ejercer al mercado de masas. En los medios de comunicación con las masas encontramos pocos indicios de censura, en el sentido de una supresión deliberada y planeada, impuesta por algún edicto moral, pero sí encontramos muchos indicios y pruebas de censura en el sentido de una supresión funcional de una gran variedad de temas: una supresión impuesta por la indiferencia del público o, más exactamente, por la creencia de aquellos que controlan los medios de que el público permanecería indiferente." Potter (1965: 245).
} 
todo esto, y qué hay de falso, si realmente disfrutamos de tanta libertad como se nos dice que disfrutamos... Tenemos la obligación de armarnos con las herramientas heurísticas de nuestra profesión, pero sin perder por el camino (a ser posible) nuestro sentido común, para ser capaces de emitir un juicio realista y ponderado. Y particularmente, en relación a esto de la organización capitalista de la producción, debemos preguntarnos sobre todo dos cosas: la primera ¿qué reglas estructurales impone el capitalismo a los que se incorporan a él? Y la segunda ¿tenemos de verdad libertad de no incorporarnos al capitalismo?

5. Para poder contestar a esas preguntas debemos comprender que el capitalismo tiene todas las características que Èmile Durkheim exigía a un hecho para ser social, y particularmente la nota con la que más definía a ese concepto: su condición represiva, coactiva: que ese modo de comportamiento se impone al individuo lo quiera o no. $\mathrm{Y}$ en efecto, tarde o temprano todos tenemos que buscarnos la vida en el mercado (o en la administración de su sociabilidad): nadie lo va hacer por ti.

Pero el mismo Durkheim distinguía entre hechos sociales que realizan una coacción directa sobre el individuo, una represión o reacción penal fácilmente perceptible, como ocurre con el caso del Derecho, o con el reglamento de una organización burocrática, o también con la desaprobación de una pequeña comunidad local o de una secta religiosa o política etc. etc. $Y$ aquellos otros hechos sociales que realizan una coacción no menos eficaz sobre el individuo, pero que proceden a castigarlo de manera indirecta, como una mera consecuencia o resultado del actuar espontáneo, normativo, de todos los demás partícipes:

"Si soy francés no estoy obligado a hablar francés con mis compatriotas, ni a emplear la moneda francesa legal, pero es imposible que obre de otro modo. Si pretendiese escapar a esta necesidad, mi intento fracasaría miserablemente. Si soy un industrial, nada me impide trabajar con los procedimientos y métodos del siglo pasado; pero si lo hago, me arruino sin duda alguna." Durkheim (1978: 34-35).

Desde luego, cada una de las empresas capitalistas, si ha de sobrevivir como tal, ha de obtener beneficios, generar ese plus-valor que según la teoría marxiana es el fin mismo de su actividad, y estará por lo tanto como tal empresa en sí misma por fuerza sometida a esta contabilidad:

\section{$\sum$ f. de T. $\Leftrightarrow \mathrm{pl}^{\wedge}$.}

Es decir: que la continuidad de la actividad en que consista su particular proceso de trabajo o de servicios, y por ello, la continuidad en el empleo de la fuerza de trabajo (f. de T.) de los individuos que turno tras turno la realizan, solo será posible $(\Leftrightarrow)$ en la medida en que dicha empresa consiga una y otra vez generar esa plusvalía siempre reinvertida $\left(\mathrm{pl}^{\wedge}\right)$. Pero dicha actividad es una acción indivisa, resultado de la coordinación $(\Sigma)$ de la actividad de cada uno de los asalariados con la actividad de todos los demás que participan en ella, asalariados que estarán por ello sometidos a una misma y orientada disciplina, 
a la vigilancia de quienes los emplean, de los representantes políticos de la persona jurídica propietaria del negocio y sus medios de producción. Esa disciplina que rige el grupo humano que lleva a cabo la actividad empresarial, no puede conseguirse sino (como en cualquier otra disciplina grupal) sino gracias al eventual, pero sistemático castigo de los individuos que faltan a tal disciplina, siendo (entre los empresarios) la expulsión la manera preferida de penalización, de ahí la progresiva liberalización del despido que los empresarios han ido consiguiendo en todas las sociedades a medida que el capitalismo ha ido avanzando su dominio en ellas:

"With unemployment (...) a worker has an incentive not to shirk. For, if he is fired, an individual will not immediately obtain another job. The equilibrium unemployment rate must be sufficiently large that it pays workers to work rather to take the risk of being caught shirking".

"The punishment associated with being fired is endogenous, as it depends on the equilibrium rate of unemployment". Shapiro and Stiglitz (1984: 433). [cursivas nuestras] $^{45}$

Pero como ya sabemos (en realidad no hablamos de otra cosa), la fuerza de trabajo no es una mercancía más, pues aunque se encuentra y se compra y se vende en el mercado como cualquier otra, no es como un litro de aceite, un coche o una casa, que al tiempo que se consumen desaparecen o pierden

\footnotetext{
${ }^{45}$ Y es por ahí, por la relación entre delitos (shirking) y penas (firing), por donde vemos nosotros que se abre una posible vía para esa medición matemática del capitalismo, que más arriba (vid. I. 8) juzgábamos urgente.
}

En efecto, todo este tiempo hemos venido manteniendo que cualquier acción grupal normativa (entre todos los individuos de un grupo) no puede producirse sin una concomitante acción punitiva (del grupo como tal sobre cada uno de ellos). Pero yendo ahora un poco más allá, y caracterizando la acción represiva misma, reconocemos una reiterada proporcionalidad entre los delitos que se cometen y las penas que se infringen, que ya fue señalada por Durkheim (1973: 90):

"(...) la proporcionalidad que observamos en todas partes entre el crimen y el castigo, se establece, entonces, con una espontaneidad mecánica, sin que sea necesario hacer cómputos sabios para calcularla." [cursivas nuestras]

No se necesitan cómputos sabios para calcular (y aplicar) dicha proporcionalidad, porque en realidad no hacemos otra cosa desde que nacemos, en nuestra vida social, pues es así como se construye la conciencia colectiva, cualquiera que sea su contenido: con la participación incesante de todos y cada uno de los miembros del grupo.

Pero si queremos aplicar cabalmente esta hipótesis general a nuestro particular hecho social en estudio (el capitalismo), debemos descartar los delitos por motivos de conflicto, o

fricciónales, ciñéndonos en cambio tan solo a los estrictamente contables: esto es: a la proporcionalidad endógena entre delitos por falta de plusvalorización $(\mathrm{t}<\mathrm{v})$ y sus consecuentes penalizaciones (despidos objetivos), proporcionalidad que ha de manifestarse (y de hecho se manifiesta) en regularidades estadísticas.

No existe entonces nada, en principio, desde el punto de vista científico, que se oponga a que dichas regularidades estadísticas se expresen algún día por medio de fórmulas matemáticamente definidas (y no meramente empíricas).

Sobre los fundamentos sociológicos de todo esto, puede verse Allones Pérez $(2004,2005)$. 
valor, sino que entre todas las demás mercancías, ésta de la fuerza de trabajo ajena, presenta la exclusiva y peregrina cualidad de que cuando se consume engendra nuevo valor, en realidad más valor del que ha costado alquilarla.

De ahí que ese entramado de empresas en que consiste el mercado en su aspecto productivo, prima, selecciona, sistemáticamente, como ya en su momento se dijo (vid. I. 7), la incesante reinversión de la plusvalía obtenida (pl.^), ya que tan solo la ampliación de la compra y consumo de más y más fuerza de trabajo otorga a cada empresario la oportunidad de ganar en la lucha diaria con los otros empresarios del mismo sector, a los que quiere expulsar de su mercado (en ello le va el éxito su identidad personal).

Por eso mismo, cada empresa no está sometida únicamente a aquella contabilidad propia que la obliga a obtener una plusvalía como resultado de su actividad, sino que a mayores, y como una condición a priori de esa misma contabilidad, esa plusvalía ha de ser al menos igual, sino superior, a la que corresponde a la tasa de beneficio media de las otras empresas (que concurren con ella en el mercado):

$\left[\Sigma \text { f. de T. } \Leftrightarrow \text { pl. }^{\wedge}\right]^{\wedge}$

Es así como la contabilidad general del mercado, coacciona de esta manera tan indirecta, pero tan eficaz, la contabilidad particular de cada una de las empresas que concurren en él, siendo la primera contabilidad en realidad un prius o conditio sine quae non de la segunda. Poniendo a cada una de las empresas en peligro constante de ser absorbidas por la competencia de todas las demás, en caso de no poder mantener sus resultados contables, al nivel moderno de explotación que requiere el mercado en cada momento.

6. Esa doble contabilidad que coacciona a la empresa particular -una, la del momento histórico del mercado en el que se inscribe; dos, la propia de la empresa misma- disciplina ferozmente el consumo de fuerza de trabajo allí donde y cuando quiera se produzca, generando con eso mismo una exponencial difusión e intensificación de la compraventa de fuerza de trabajo, una incesante expansión del capitalismo, que se nos presenta al análisis como una moneda de dos caras:

$1^{\text {a) }}$ Una expansión que podemos llamar centrífuga, hacia fuera, por la cual más y más sectores se van incorporando a esta organización capitalista de la producción, bien por creación ex novo de los mismos, o por transformación de las viejas artesanías, incapaces de competir (también en términos de distribución de riqueza) con ella. Es así como la vieja agricultura, la vieja casa de labranza (que era abrumadoramente mayoritaria entre las poblaciones europeas proto-capitalistas) se va convirtiendo en industria agropecuaria, so pena de desaparecer, en un sector más del mercado, con el recurso característico al trabajo asalariado y a la maquinaria, al uso de técnicas especializadas, transgénicos, clonaciones, cultivos ecológicos, etc. etc.

Lo que importa resaltar aquí es lo ya sabido: que los campesinos y los artesanos eran dueños de sus tierras y casas y medios de su actividad, y todo eso pierden y dejan atrás a medida que se incorporan al trabajo asalariado, del que pasan a depender absolutamente para sobrevivir, de modo que o trabajan 
por cuenta ajena o no trabajan, pues ya no tienen medios propios para realizar por su cuenta actividad productiva alguna. ${ }^{46}$

Todavía tendremos que comentar en algo las obvias consecuencias que para nuestra famosa libertad tiene esta generalizada pérdida de medios propios de producción que caracteriza fatalmente a nuestras poblaciones, precisamente porque se han incorporado ya por completo a la organización capitalista del trabajo.

$\left.2^{a}\right)$ Pero esa expansión del capitalismo no podría haberse dado sin una simultánea expansión centrípeta, hacia dentro, del consumo de la fuerza de trabajo, sin una imposición cada día más exigente de su horrible disciplina contable, en cada una de las empresas en las que se realiza dicho consumo. Ahí, a pie de planta y de oficina, día tras día, se inventan las máquinas que permiten su mejor rentabilización, forzando a las personas que aspiran a trabajar con esas sofisticadísimas maquinarias, a diseñar a largo plazo su curriculum escolar y laboral, a los fines de habilitarse para su manejo.

Para sobrevivir en estas condiciones, cada persona ha de convertirse en una empresaria de si misma, en una self-made-woman o self-made-man, todavía tal vez ilusionada con la sensación de que se está haciendo dueña de su propio destino, cuando en realidad está convirtiendo a su persona en un individuo: esto es: en una pieza perfectamente intercambiable con otros que son como él o como ella (también individu@s), igualmente aptos para participar en la organización seriada del trabajo, que impone la absurda contabilidad capitalista.

Pero ya hemos comentado que algunos, sin embargo, a la vista de estas trayectorias curriculares que todos nos vemos obligados a diseñar (para mejor sobrevivir en el capitalismo), parecen contentarse (y hasta entusiasmarse) con tan poca cosa, creyéndolas un genuino ejercicio of freedom. $Y$ hasta cierto punto en efecto lo son, pero un punto estrictamente limitado, pues no se trata sino de un aprovechamiento de las libertades que concede la dominación capitalista... ${ }^{47}$

\footnotetext{
${ }^{46} \mathrm{O}$ trabajas para el capitalismo, o no trabajas. Lo que obliga al Estado a ampliar sus prestaciones para proteger a esos millones de personas que no tienen ya medios propios de producción, pero que no encuentran tampoco donde vender su fuerza de trabajo, cayendo en el paro, en el desempleo. Esos parados de toda condición son invisibles para el sistema capitalista, pues el capitalismo (y por extensión de su influencia, las sociedades altamente capitalizadas en las que vivimos) solo reconoce a las personas por su productividad, juzgando culpables (como hace por lo demás cualquier otro juego social) a todos los que no lo sirven. Por eso no solo los desempleados, sino también las amas de casa, los ancianos, los enfermos, los bebés, los dependientes etc. etc. son entre nosotros no solo parados, sino verdaderos parias, y así los considera nuestra conciencia colectiva (más allá del buen rollito ritual). Por lo que el Estado (llamado entonces de Bienestar) ha de proveer grandes partidas de sus presupuestos para pagar una nómina ficticia a esos (y a otros) colectivos, intentando en lo posible paliar su desesperada y estigmatizada situación.

Pero esas ayudas del Estado de Bienestar no son, no pueden ser (estructuralmente hablando) en realidad otra cosa, que limosna institucionalizada, vía impuestos (lo que no quiere decir que estemos en contra de ellas). Sobre esto, puede verse Vilas Nogueira (1980).
}

${ }^{47}$ El capitalismo ha hecho posible un indudable y maravilloso y nunca visto progreso de las profesiones, pero también las ha envilecido, encanallado. Médicos, arquitectos, filósofos, 
De manera que para las dos preguntas que nos hacíamos, a saber, ¿qué reglas estructurales impone el capitalismo a los que se incorporan a él?, ¿y si tenemos o no libertad de trabajar o no trabajar para el capitalismo?, vemos a la primera muy contestada haciendo referencia a esa omnipresente doble contabilidad

$\left[\sum \text { f. de T. } \Leftrightarrow \text { pl.^}^{\wedge}\right]^{\wedge}$

que nosotros defendemos (con la fe del carbonero) que obliga a todas las empresas y a sus empleados a perfeccionar cada día más la explotación recíproca, en una espiral enloquecida y sin fin, que no nos gusta pero qué nada...Y que cada día nos gusta menos.

En cuanto a la segunda cuestión, que no se refiere ya a las libertades dentro del capitalismo, en el capitalismo, sino a sí disfrutamos de libertad de el capitalismo, con respecto al capitalismo... Esta segunda cuestión, digo, para ser contestada cabalmente (mejor dicho, para intentar contestarla cabalmente) requiere de nosotros todavía algo más de dedicación y tiempo.

"¿Por qué dividendos? Tal y como ya he explicado, defino las empresas sociales como empresas que no generan ni pérdidas ni dividendos. Danone estuvo completamente de acuerdo con este planteamiento, pero, en el último instante, añadimos al Memorando de Entendimiento (entre las dos organizaciones) la provisión de un dividendo simbólico del 1\%, como reconocimiento público de la propiedad de la empresa y para que Danone pudiera reflejar una cifra en la línea adecuada de sus libros de contabilidad. (Ahora, con la experiencia y habiendo tenido la oportunidad de reflexionar más sobre ello, me decanto por eliminar la cláusula del dividendo y que la empresa no pague dividendo alguno. Si Danone accede, lo haremos así, para que la empresa coincida con la definición de 'empresa social' tal y como yo mismo la he formulado: sin pérdidas y sin dividendos.)" Un mundo sin pobreza. Las empresas sociales y el futuro del capitalismo, Muhammad Yunus, 2008

\section{Industrias post-capitalistas}

Si queremos ganar verdadera libertad con respecto al capitalismo, si queremos ponernos en una posición estructural que nos haga independientes de él, que nos libre de la realidad y la amenaza del desempleo, tenemos que crear y sostener industrias que no sean capitalistas, industrias post-capitalistas.

Industrias post-capitalistas, de acuerdo, suena muy bien, es fácil decirlo, ¿pero cómo crearlas? ¿Y cómo mantenerlas?

científicos, profesores, estadistas, ingenieros, periodistas, todos hemos mejorado espectacularmente (como nunca antes en la historia humana) nuestros oficios y herramientas, que están ahí a nuestro alcance para hacer el bien a los demás. Pero no es a eso a lo que nos dedicamos, objetivamente. En realidad solo trabajamos para empresas que solo buscan ganar cada vez más, o en organizaciones de funcionarios que se han hecho fuertes sirviendo sus propios privilegios. Las profesiones se han desacralizado, y 'algo huele a podrido' en todas ellas. 
Lo más importante es ese post-: sólo las personas con experiencia profesional dentro del capitalismo, y que decidan salirse del capitalismo, saltar afuera, están capacitadas para crear agrupaciones productivas o serviciales, cuya finalidad sea proveer buenos bienes y servicios a sus clientes, tecnológicamente avanzados (pero duraderos), rechazando maximizar el beneficio, rechazando volver a reinvertirlo una y otra vez, rechazando crecer por crecer.

Lo más importante, ya digo, es esa experiencia de desengaño del juego capitalista, vencida la superchería del dinero y de la técnica, por gente que sepa, por experiencia personal, de capitalismo, por personas que ya se han demostrado a sí mismas su capacidad de sobrevivir en el capitalismo, pero que también han renunciado a toda posición de poder en él (o en la administración): tanto a ejercer poder dentro del capitalismo, como a seguir sufriendo ese poder.

Lo más importante es ese post-, ese venir de vuelta, ese 'volver a cruzar' (después de haberse incorporado al capitalismo, 'volver a cruzar' para salir del capitalismo, para no depender de él, para librarse de él). ${ }^{48}$

Bueno, sí, de acuerdo, personas que vienen de vuelta, personas desencantadas, ¿pero cómo pueden crear esas personas producciones o servicios post-capitalistas? ¿Y cómo podrán sostenerlos, en medio de la omnipresente y competente eficacia (en lo suyo) y prestigio de las actuales y futuras empresas del capitalismo?

Es difícil, pero no imposible. Se trata de un doble movimiento: por un lado, desde luego, tendremos que ganarnos la vida trabajando para empresas capitalistas, y hasta montando tales empresas, participando por tanto en estas relaciones:

$\left[\sum \text { f. de T. } \Leftrightarrow \text { pl.^ }\right]^{\wedge}$

pero por otro, lo haremos siempre con la vista puesta en aprovechar hábilmente toda esa experiencia empresarial y laboral acumulada, para coaligarnos con otros hombres y mujeres, profesionales como nosotros, a los fines de crear agrupaciones productoras y servidoras que rompan, que quiebren esa regla de juego.

Utilicemos todas las libertades, todas las tecnologías, todos los saberes escolarizados, todas las ventajas que otorga el capitalismo a sus súbditos/ciudadanos (que no son pocas), para superarlo, para salirnos de él, para librarnos de él, para aunarnos con otros que tampoco soporten por más tiempo seguir dependiendo del capitalismo, y de sus ciclos económicos ciegos, y sus crisis fatales.

\footnotetext{
48 'Volver a cruzar' en el sentido que define estrictamente la lógica de Spencer-Brown (1979: 17).
} 
Porque en efecto, en la medida en que consigamos junto con otros mantener producciones o servicios que en su funcionar diario hayan conseguido (tendencialmente) cancelar la regla fundacional del juego capitalista:

f. de $T .<=/=>$ pl.

en esa misma medida, digo, no solo empezaremos a respetarnos a nosotros mismos, y entre nosotros, sino que también habremos empezado a respetar a nuestros clientes, que sintiéndose mejor tratados, nos serán fieles, haciéndonos (hasta cierto punto) inmunes a las crisis económicas del capitalismo, y evitándonos (hasta cierto punto) el riesgo del desempleo, facilitándonos por ello, a nosotros, que los proveemos, una vida más segura, más reconciliada, y más digna. Con esas agrupaciones post-capitalistas conseguiremos lo que con el capitalismo nunca podríamos conseguir: perderle el temor al desempleo, ser de verdad personas más independientes, más dueñas (en lo que lo permite la limitada condición humana) de su propia vida.

Pero no nos engañemos, este empeño de liberarnos del capitalismo que aquí estamos planteándonos, no es tarea para una sola generación, no es una ocupación tan solo para los que vivimos, sino que se trata de una larga obra, una larga dedicación, tal vez de $\operatorname{siglos}^{49}$. Pues para la humanidad el capitalismo, la era del capitalismo, no ha hecho más que empezar (que se lo digan sino a las entusiastas poblaciones que recién se le están incorporando, en México, en Brasil, China, o India; en Rusia, Polonia, o Eslovaquia; en Sudáfrica y demás naciones africanas). De ahí que no basta con crear y afianzar esas nuevas industrias productoras y serviciales post-capitalistas (y las sociabilidades y tecnologías cualesquiera que les sean concomitantes), sino que al mismo tiempo -pero esto será un sentimiento que surgirá en nosotros sin esfuerzo alguno, espontáneo y tenaz-, sin darnos cuenta siquiera, digo, casi sin proponérnoslo, empezaremos a tener tiempo para educar a nuestros hijos, generación tras generación, en un esfuerzo civilizatorio, que (repito) surgirá espontáneo, que irá abriendo, extendiendo y profundizando más y más dichas productividades post-capitalistas -y sus inherentes y (hoy) desconocidas tecnologías y sociabilidades-, de modo que cuando adultos, esos hijos nuestros tengan efectivamente capacidad de experimentar por sí mismos el capitalismo, si así lo desean, pero también la capacidad de prescindir de él, si por el contrario lo prefieren, siguiendo para ello con mayor facilidad el camino ya trillado por nosotros, sus padres.

\footnotetext{
${ }^{49}$ Vid. supra nota 20 y el fragmento de Macfarlane al que se refiere.
} 


\section{BIBLIOGRAFÍA}

ALLONES PÉREZ, Carlos (1999a): Familia y Capitalismo, Universidad de Santiago de Compostela

ALLONES PÉREZ, Carlos (1999b): Burocracia: el mito y su crónica. Revista RELEA, núm. 8, pp 155-165. Caracas

ALLONES PÉREZ, Carlos (2004): El valor de las leyes estadísticas en la física y en las ciencias sociales, de Ettore Majorana. Biografía, traducción, comentario sociológico. Revista Empiria. Revista de metodología de ciencias sociales, $n^{0} 7$, pp 183-209. UNED

ALLONES PÉREZ, Carlos (2005): Teoría de la Acción Social: propuesta de un método. Revista de Investigaciones Políticas y Sociológicas, vol. 4, núm. 2, pp 57-68. Universidad de Santiago de Compostela.

BALANDIER, George (1975): Antropo-lógicas, Barcelona: Península BOÉTIE, Ètienne de la (2008): Discurso de la servidumbre voluntaria, Madrid: Trotta.

BÖHM-BAWERK, Eugen von(2000): La Conclusión del sistema marxiano, Madrid: Unión Editorial.

BRITNELL, Richard H. (1991): The towns of England and northern Italy in the early fourteenth century. Economic History Review, XIV, I, 1991, pp 21-35.

DURES, Alan. (1983): English Catholicism 1558-1642, Essex: Longman Group Limited.

DURKHEIM, Émile (1973): La división del trabajo social, Buenos Aires:

Schapire

DURKHEIM, Émile (1978): Las reglas del método sociológico, Madrid: Akal.

ENCYCLOPAEDIA BRITANNICA ON-LINE (2010)

FINLEY, Moses I. (1975): La Economía de la Antigüedad, México: FCE.

GARCÍA CALVO, Agustín (1979): Del Lenguaje, Madrid: Editorial Lucina.

GONZÁLEZ GARCÍA, Teodoro (1927): La soberanía del Parlamento inglés: su evolución política, su estado actual. Universidad de Murcia.

GUIZOT, François (1985): Historia de la Revolución de Inglaterra. Madrid: Sarpe.

HAYEK, Friedrich A. (1948): Individualism and Economic Order. The University of Chicago Press.

HILL, Christopher (1972): The World turned upside down. England: Penguin Books.

HOBBES, Thomas (1979): Leviatán. Madrid: Editora Nacional. (Edición a cargo de C. MOYA y A. ESCOHOTADO).

HOBBES, Thomas (1985): Leviathan. Great Britain: Penguin Classics. (Edición a cargo de C. B. MACPHERSON).

HOFFER, Eric (2009): El verdadero creyente. Madrid: Tecnos.

HOMANS, George C. (1975): English villagers of the thirteenth Century. London, New York: Norton and Co.

IGLESIAS RÁBADE, Luis (1992): El uso del inglés y francés en la Inglaterra Normanda y Plantagenet (1066-1399). USC.

JONES, J. A. P. (1971): King John and Magna Carta. England: Longman Group Ltd. 
MACFARLANE, Alan (1978): The origins of English individualism. Oxford: Basil Blacwell.

MARX, Karl (1975): El Capital. Crítica de la Economía Política. Madrid: Siglo $X X I$.

MORGAN, Edmund S. (2006): La invención del Pueblo: El surgimiento de la soberanía popular en Inglaterra y los Estados Unidos. Argentina: Siglo XXI.

MOYA, Carlos (1984): Señas de Leviatán. Estado nacional y sociedad industrial: España 1936-1980. Madrid: Alianza.

OAKESHOTT, Michael J. (1948-9): The Tower of Babel. The Cambridge Journal, vol. 2. pp 67-83.

ONIONS, C. T. Ed. (1985): The Oxford Dictionary of English Etymology. Oxford University Press.

POSTAN, Michael M. (1972): The medieval Economy and Society (An economic History of Britain, 1100-1500). University of California Press.

POTTER, David M. (1965): La Prosperidad de un Pueblo. Estudio de la abundancia económica en relación con el carácter norteamericano. México: Libreros Mexicanos Unidos.

RAMIRO RICO, Nicolás (1952): La Soberanía. En Revista de Estudios Políticos, vol. XLVI, núm. 66.

RAMIRO RICO, Nicolás (1980): El Animal Ladino. Madrid: Alianza Editorial. RAYNER, Doris (1941): The Forms and Machinery of the 'Commune Petition' in the Fourteenth Century. Parts I and II. The English Historical Review, vol. 56, $\mathrm{n}^{\circ}$ 222, pp 198-233 y n² 224, pp 549-570.

ROBBINS, Keith (1989): Nineteenth Century Britain. England, Scotland and Wales. The Making of a Nation. Oxford University Press.

SHAPIRO, Carl and STIGLITZ, Joseph E. (1984): Equilibrium Unemployment as a Worker Discipline Device. The American Economic Review, vol. 74, núm 3, 433. y ss.

SIMMEL, George (1904): Fashion. International Quartely, núm. 10, 130-155.

SOREL, Georges (2005): Reflexiones sobre la violencia. Madrid: Alianza.

SPENCER-BROWN, Georges (1979): Laws of Form. New York: E. P. Dutton.

SRAFFA, Piero (1960): Production of commodities by means of commodities. Cambridge University Press.

TOCQUEVILLE, Alexis de (1989): La Democracia en América (Tomos I y II). Madrid: Aguilar.

TÖNNIES, Ferdinand (1979): Comunidad y Asociación. Barcelona: Península.

TURNER Frederick J. (1958): The Frontier in American History. New York: Henry Holt and Company.

VEBLEN, Thorstein (2005): Conspicuous consumption. London: Penguin Books.

VER STEEG, Clarence L. (1964): The formative years, 1607-1763. New York: Hill and Wang.

VILAS NOGUEIRA, José (1980): Igualdad jurídica y desigualdad económica en el Estado Capitalista: Ios derechos sociales. Revista de Estudios Políticos, núm. 14, marzo-abril, pp 111-123.

YUNUS, Muhammad (2008): Un mundo sin pobreza. Las empresas sociales y el futuro del capitalismo. Barcelona: Paidós. (Traducción: Montserrat Asensio) WEBER, Max (1964): Economía y Sociedad. México: FCE. 